Poverty and Inequality in Britain: 2006

Mike Brewer

Alissa Goodman

Jonathan Shaw

Luke Sibieta

The Institute for Fiscal Studies 


\title{
Poverty and Inequality in Britain: 2006
}

\author{
Mike Brewer \\ Alissa Goodman \\ Jonathan Shaw \\ Luke Sibieta
}

Institute for Fiscal Studies

Copy-edited by Judith Payne

The Institute for Fiscal Studies

7 Ridgmount Street

London WC1E 7AE 


\section{Published by}

The Institute for Fiscal Studies

7 Ridgmount Street

London WC1E 7AE

Tel: +44 (0)20 72914800

Fax: +44 (0)20 73234780

Email: mailbox@ifs.org.uk

Website: www.ifs.org.uk

\section{Printed by}

Patersons, Tunbridge Wells

(C) The Institute for Fiscal Studies, March 2006

ISBN-10: 1-903274-45-1

ISBN-13: 978-1-903274-45-3 


\section{Preface}

We are very grateful for financial support from the Nuffield Foundation, grant number OPD/32190. The Nuffield Foundation is a charitable trust established by Lord Nuffield. Its widest charitable object is 'the advancement of social well-being'. The Foundation has long had an interest in social welfare and has supported this project to stimulate public discussion and policy development. Co-funding from the ESRC-funded Centre for the Microeconomic Analysis of Public Policy at IFS (grant number M535255111) is also very gratefully acknowledged. Data from the Family Resources Survey and the Households Below Average Income data-sets were made available by the Department for Work and Pensions, which bears no responsibility for the interpretation of the data in this Commentary. Material from the Family Expenditure Survey was made available by the Office for National Statistics through the ESRC Data Archive and has been used by permission of the Controller of HMSO. Any errors and all views expressed are those of the authors. 



\section{Contents}

$\begin{array}{ll}\text { Executive summary } & 1\end{array}$

1. Introduction 4

1.1 How are incomes measured in this Commentary?

1.2 How is poverty measured in this Commentary? 8

$\begin{array}{ll}\text { 2. } & \mathbf{1 0}\end{array}$

2.1 The income distribution in 2004/05 10

2.2 Changes in living standards $\quad 12$

2.3 What has happened to income inequality? 18

2.4 Conclusion 27

3. Poverty in Britain $\quad 28$

3.1 The whole population $\quad 29$

3.2 Child poverty and the 2004/05 target 32

$\begin{array}{lll}3.3 & \text { Pensioner poverty } & 37\end{array}$

3.4 Poverty among other groups 42

3.5 Conclusion 42

4. Child poverty from 1998/99 to 2004/05: 43

why did it fall, and why didn't it fall far enough?

4.1 How was the fall in child poverty achieved? 43

4.2 Why did the government miss its child poverty target for 2004/05?

4.3 The prospects for child poverty in 2010/11 55

$\begin{array}{ll}4.4 \text { Conclusion } & 58\end{array}$

$\begin{array}{lll}\text { 5. Conclusion } & 60\end{array}$

\section{Appendices}

A. The implications of the switch to Modified OECD equivalence scales 63

B. Supplementary tables for Chapter $2 \quad 66$

C. Summary measures of inequality 68

D. Decomposition of falls in poverty $\quad 70$

E. Supplementary tables for Chapter $4 \quad 72$

F. Children in workless families $\quad 76$

$\begin{array}{ll}\text { References } & 78\end{array}$ 



\section{Executive summary}

This Commentary provides an update on trends in poverty and inequality in Great Britain, based on the latest official government statistics. It uses the same approach to measuring incomes and poverty in Great Britain as the government employs in its Households Below Average Income (HBAl) publication.

\section{Living standards and inequality}

- In 2004/05, almost two-thirds of the population had incomes below the national average equivalised income of $£ 427$ per week. The distribution is skewed by a relatively small number of people on relatively high incomes. Median equivalised income in 2004/05 was £349 per week - in other words, half the population had household income below this amount, after adjusting for family size.

- There was modest growth in average incomes between 2003/04 and 2004/05, with mean income rising by 1.4 per cent in real terms (from £421 to £427) and the median income rising by 1.1 per cent (from £346 to £349). These changes are not statistically significant.

- Between 1996/97 and 2004/05, mean income has risen by an average of 2.4 per cent per annum. But the average annual growth in mean and median incomes since 2002/03 has been considerably lower than between 1996/97 and 2002/03. Though this may be due to sampling error, it appears that growth of average living standards has slowed in recent years.

- Since 1996/97, on average, the fastest rises in mean and median incomes have been amongst lone parents and single pensioners. The region with the largest growth in average incomes has been London, though once housing costs have been taken into account, differences in incomes and income growth between regions are much less pronounced.

- Between 1996/97 and 2001/02, income inequality rose on a variety of measures, to reach its highest ever level (at least since comparable records began in 1961) as measured by the Gini coefficient. Since then, income inequality has fallen, and it is now at a similar level to that in 1996/97: the net effect of eight years of Labour government has been to leave inequality effectively unchanged.

\section{Child poverty}

- By $2004 / 05$, child poverty had fallen by 700,000 since 1998/99 (measuring incomes after housing costs $(\mathrm{AHC})$ or before housing costs $(\mathrm{BHC})$ ), and it is now at its lowest level since the late 1980s. But the government fell 100,000 children short of meeting its target for 2004/05 measuring incomes BHC and 400,000 children short measuring incomes $\mathrm{AHC}$. 
- The main factors contributing to the decline in poverty since $1998 / 99$ are the substantial declines in the proportion of children in workless households and large falls in the risk of poverty for children in workless families, those with parttime working lone parents and those in couple families with one full-time parent and one non-working parent. And child poverty has fallen despite a rise in the proportion of children living in lone-parent families, who are at over twice the risk of poverty that couples with children are (measuring income $\mathrm{AHC}$ ).

- The government can take much credit for this fall in child poverty, both through its decisions to increase substantially the amount of cash transfers made to families with children and through welfare-to-work and other policies that have helped parents in previously workless families to find work and therefore increase their incomes.

- Forecasts made two years ago by civil servants and by independent researchers implied that the government was on track to meet its child poverty targets. These forecasts overstated the decline in child poverty since 2001/02 by around $300,000-400,000$. It is too early to say definitively why these forecasts were too optimistic, although forecasts of child poverty in particular are extremely sensitive to sampling and modelling error because 800,000 children were living in households within 5 per cent of the poverty line in 2004/05.

- Another contributing factor could be that the survey used to estimate child poverty - the Family Resources Survey - is recording a decreasing proportion of government spending on tax credits at a time when tax credits have become the government's main instrument for reducing child poverty; this may mean that HBAI is increasingly overstating the true level of child poverty. The government should review the ability of the FRS to record accurately families' income from tax credits, given that the government will be using the FRS to track progress towards its future targets for child poverty.

- As a result of missing this year's target by 100,000 (measured BHC) and of changes to the way child poverty will be measured for the $2010 / 11$ target to reduce child poverty to half the level of $1998 / 99$, child poverty now has to fall by about 1 million between 2004/05 and 2010/11. This represents a fall over oneand-a-half times greater than the 600,000 fall between 1998/99 and 2004/05. This will need to be achieved with a lower planned growth rate in social security expenditure. We therefore feel that unless the government is to fall short of this target, or there are radical shifts in parental working patterns, new spending will be needed, from extra borrowing, increased taxation or a reordering of spending priorities. 


\section{Poverty amongst other groups}

- The biggest falls in relative poverty over the past eight years have been amongst the pensioner population. Since 2003/04, pensioner poverty has fallen by 2.7 percentage points measured $\mathrm{AHC}$ and 1.5 percentage points measured $\mathrm{BHC}$, and since 1996/97 the poverty rate has fallen by over a third measured AHC and 18 per cent measured BHC. There are now 1.8 million pensioners in relative poverty measured $\mathrm{AHC}$ and 2.0 million in poverty measured $\mathrm{BHC}$. The poverty rate amongst pensioners measuring income $\mathrm{AHC}$ (at 17.0 per cent in 2004/05) continues to be lower than that amongst the entire population (at 19.9 per cent).

- Pensioner incomes have seen large rises over the last few years, particularly among single pensioners, and this has led to the falls in pensioner poverty. Part of this rising income is likely to have come from higher levels of public expenditure on pensioner benefits such as the pension credit and the winter fuel allowance. Although these measures have certainly reduced the risk of being in poverty for pensioner cohorts, the fall in poverty is also due in part to the changing composition of the pensioner population, as newer (generally richer) cohorts reach retirement age and older ones die out.

- Poverty amongst the working-aged non-parent population has received little government attention, and it is now about 1 percentage point higher than it was in 1998/99, on both BHC and AHC measures.

- Overall, there are now 11.4 million individuals in poverty measured $\mathrm{AHC}$ and 9.2 million measured $\mathrm{BHC}$, down from 13.8 million and 10.2 million respectively in $1996 / 97$ - the numbers fell by 500,000 and 300,000 respectively in $2004 / 05$ alone. The proportion of the population in poverty measured AHC has fallen from just under a quarter in 1996/97 to a fifth in 2004/05, with a slightly smaller fall measured BHC. Although poverty is therefore lower than at its 1996/97 peak, it remains considerably higher than it was before its steep rise during the 1980s. For example, the AHC poverty rate fluctuated around an average of about 13.5 per cent throughout the 1960s and 1970s, compared with 19.9 per cent in $2004 / 05$. 


\section{Introduction}

This Commentary presents an analysis of the latest low-income figures, released by the Department for Work and Pensions (DWP) on 9 March 2006 (Department for Work and Pensions, 2006). These figures tell us about the extent of income inequality and income poverty in Great Britain up to and including the financial year 2004/05.

We begin by outlining how the income statistics produced by the government are measured, and then, in Chapter 2, our analysis commences by looking at the current distribution of income. We look at how average incomes have changed and at what has been happening to income inequality, comparing the record of Labour with those of previous governments.

Following our analysis of inequality, we examine in Chapter 3 the recent trends in relative poverty amongst the population as a whole and within a number of different demographic groups, including children, pensioners and working-age individuals without children. Chapter 4 looks in more detail at the child poverty target for 2004/05. Chapter 5 concludes.

\subsection{How are incomes measured in this Commentary?}

All the figures in this Commentary rely on household income data derived from the latest official Households Below Average Income (HBAI) statistics (Department for Work and Pensions, 2006). These use weekly household income from all sources (earnings, state benefits, investments, pensions, etc.) net of direct taxes (income tax, National Insurance and council tax) as a measure of living standards. The incomes are calculated using information collected from the annual Family Resources Survey (FRS), a representative survey of around 45,000 people in 25,000 households in Great Britain. ${ }^{1}$ In this section, we describe briefly the main features of the HBAI income measure on which our analysis is based, and discuss some of the advantages and disadvantages of measuring living standards in this way.

\section{Income as a measure of living standards}

The approach to living standards taken in HBAI is to focus solely on material circumstances, and to use income as a simple proxy. Income provides an indirect measure of living standards, effectively capturing the financial capacity to achieve a given level of material well-being, rather than that well-being itself.

Even as a measure of material well-being, the HBAI income measure has some important limitations. For example, the income measure here is a 'snapshot' measure - reflecting actual, or in some cases 'usual', income around the time of the FRS interview. Income measured in this way will reflect both the temporary and the long-run circumstances of individuals, although the latter would generally be regarded as a better measure of welfare. Income-based statistics will also attribute the same level of welfare to people with the same income, regardless of how much savings or other assets they have, or how much they spend.

\footnotetext{
${ }^{1}$ Since 2002/03, the FRS also covers households in Northern Ireland, but the official HBAI statistics presently include Great Britain households only. The results we present for years prior to $1994 / 95$ are derived from the Family Expenditure Survey (FES), a sample of around 7,000-8,000 households.
} 
Consumption would arguably make a better measure of well-being, though reliable data can be harder to collect; see Brewer, Goodman and Leicester (2006).

\section{The treatment of housing costs}

The official HBAI publications look at two measures of income. One measure captures income before housing costs are deducted (BHC) and the other is a measure after housing costs have been deducted (AHC). The government has generally treated these as complementary indicators of living standards, presenting both in its HBAI publications and in its annual audit of poverty, Opportunity for All. ${ }^{2}$ Both measures were used in setting its shortterm child poverty target for 2004/05. But the government's new child poverty measure, to be used for its ongoing poverty targets, focuses solely on BHC income (see Department for Work and Pensions (2003)). This is primarily to allow cross-country comparisons, which are most readily available on a BHC basis. The HBAI series will continue to give equal prominence to $\mathrm{BHC}$ and $\mathrm{AHC}$ incomes.

The case for using a $\mathrm{BHC}$ or $\mathrm{AHC}$ income measure was discussed in some detail in Brewer et al. (2005). In our analysis, we focus on BHC incomes when we consider the income distribution as a whole (see Chapter 2), since for the majority of individuals, housing can be thought of as a consumption item like any other and does not warrant special treatment in the income statistics. But when we focus specifically on poverty and low incomes, there are some good reasons to consider AHC income as well (see Chapters 3 and 4). This is because AHC income is likely to provide a better measure of living standards amongst social renters and pensioners who are owner-occupiers, who are particularly prevalent at the lower end of the income scale.

\section{Income sharing}

To the extent that income sharing takes place within households, the welfare of any one individual in a household will depend not only on their own income but also on those of other household members. By measuring income at the household level, the HBAI statistics implicitly assume that all individuals within the household are equally well off and therefore occupy the same position in the income distribution. For some households, this assumption may provide a reasonable approximation - for example, some couples may benefit equally from all income coming into the household. For others, such as students sharing a house, it is unlikely to be appropriate. However, given that it is not possible with the data available to observe directly how much sharing goes on, it is perhaps not too unreasonable an assumption. $^{3}$

\section{Comparing incomes across households: equivalence scales}

Households of different sizes and compositions need different amounts of income to achieve a given standard of living. For example, a weekly income of $£ 300$ will provide a much higher standard of living to an individual living alone than to a family of five. The official income

\footnotetext{
${ }^{2}$ See Department for Work and Pensions (2005a), for example.

${ }^{3}$ This is by no means the only 'reasonable' assumption that we can make: for example, we could assume that there is complete income sharing within the different benefit units of a household but not between them.
} 
statistics take this into account by adjusting household incomes for the different needs that different households face, using equivalence scales.

The current HBAI series uses the McClements scale to equivalise incomes (see McClements (1977)). This scale is used to adjust incomes so that they represent the equivalent amount that a benchmark household - in the case of the HBAI statistics, a couple with no children would require in order to enjoy the same standard of living. For example, using the McClements scale, an individual living alone with a BHC income of $£ 300$ would be calculated to have an equivalised income of $£ 492$. This is more than double the equivalised income of the household of five, which would be $£ 203 .{ }^{4}$

\section{Box 1.1. The change to Modified OECD equivalence scales from 2005/06}

From 2005/06, all HBAI statistics will be based on the Modified OECD equivalence scale rather than the McClements scale. This change has been introduced in order to align the HBAI statistics with the new child poverty measure, which uses the Modified OECD scale.

The main effect of the change from the McClements to the Modified OECD equivalence scale will be that for a given level of income, households containing children under 5 or aged 14 or 15 will appear worse off, and those with children between 5 and 13 will appear better off. Single individuals and individuals in lone-parent households will also appear worse off under the new scale, whilst households with two or more adults will appear better off.

Using the same example households as in the text above, an individual living alone with BHC income of $£ 300$ would have an equivalised income of $£ 448$ using the Modified OECD scale, whilst the household of five on the same income would have an equivalised income of $£ 188$.

Appendix A sets out the scales and shows how some headline figures about inequality and poverty, and their historical time trends, will be affected by next year's change. The appendix shows that poverty rates and inequality rates are generally slightly higher when using the Modified OECD scale rather than the McClements. However, equivalised mean and median income in 2004/05 are very similar on both scales. Chapter 4 discusses further the implications for measuring child poverty.

\footnotetext{
${ }^{a}$ The single person figure is calculated as $£ 300 / 0.67=£ 448$. For a family of five made up of a couple with three children aged 1,3 and 5 , the figure is calculated as $£ 300 /(0.67+0.33+0.2+0.2+0.2)=£ 188$.
}

From next year (i.e. using data from the year 2005/06 onwards), the official HBAI series will be produced using a different equivalence scale, the Modified OECD scale. This change will align the official HBAI statistics with the new child poverty measure, to be used for the 2010 and 2020 child poverty targets. The change will affect some of the headline statistics relating to rates of poverty and inequality, though the main historical trends in poverty and inequality will remain largely unchanged. Box 1.1, Section 4.3 and Appendix A provide some more details.

It should be noted that neither the McClements equivalence scale nor the Modified OECD scale takes into account other characteristics of the household besides the age and number of individuals in the household - despite the fact that there may be other important factors

\footnotetext{
${ }^{4}$ The single person figure is calculated as $£ 300 / 0.61=£ 492$. For a family of five made up of a couple with three children aged 1,3 and 5 , the figure is calculated as $£ 300 /(0.61+0.39+0.09+0.18+0.21)=£ 203$.
} 
affecting a household's needs. An important example of these would be the disability or health status of household members. Someone with additional income due to the receipt of disability benefits will be located higher up the income distribution than someone who does not receive these benefits but has the same other income. But if the higher level of income only compensates the first individual for the greater needs that they have, then the standard of living of this person is not any higher.

\section{Sample weighting, and adjusting the incomes of the 'very rich'}

The incomes used in this Commentary are derived from the Family Resources Survey (FRS) and, prior to 1994/95, the Family Expenditure Survey (FES). These surveys are designed to provide a broadly representative sample of households in Great Britain. ${ }^{5}$ However, because they are voluntary surveys, there is inevitably a problem of non-response, which may differ according to family type and according to income. Such non-response bias is dealt with in two ways: weights are applied to the data, and incomes at the very top of the distribution are adjusted. We discuss these procedures in turn.

Using weights makes the FRS sample look like the British population across a number of prespecified dimensions, including family structure, housing tenure and council tax band. If, for example, there are proportionately fewer lone parents in the sample than there are in the population, then a larger weight is given to data from lone parents who do respond. Following a methodological review in 2004, the weights (often called 'grossing factors') used from 2003/04 onwards (first presented in last year's HBAI publication - Department for Work and Pensions (2005b)) were different from those used previously, and the series was also altered retrospectively to reflect the methodological changes (see Brewer et al. (2005)).

The second way in which non-response bias is addressed is through a procedure applied to the incomes at the very top of the distribution to correct for the volatility in reported incomes. This adjustment procedure uses data from the HM Revenue \& Customs Survey of Personal Incomes (SPI) - a more reliable source of data for the richest individuals which is based on income tax returns rather than being a voluntary survey. The very richest individuals, for whom the SPI adjustment is applied, are assigned an income level derived from the SPI survey. For the most recent year's data, this correction was made to the incomes of the top half a per cent of the population (corresponding to around 300,000 individuals). A slight modification is made to the grossing factors to allow for this SPI adjustment. However, there is no corresponding correction for non-response, or for misreporting of incomes at the bottom end of the income scale.

\section{The income measure summarised}

In the analysis that follows, we will therefore be following the government's HBAI methodology, using household equivalised income after deducting taxes and adding benefits, expressed as the equivalent income for a couple with no dependent children and in average 2004/05 prices, as our measure of living standards; unless stated otherwise, the McClements equivalence scale will be used. For brevity, we shall be using this term interchangeably with

\footnotetext{
${ }^{5}$ Both have samples from Northern Ireland, but these are not analysed here.
} 
'income'. Sometimes we shall be referring to incomes measured before housing costs and sometimes to incomes measured after housing costs; this will be made clear in the text.

\subsection{How is poverty measured in this Commentary?}

In the discussion of poverty in Chapter 3, we will classify individuals as being in poverty if they live in households whose income falls below some poverty line expressed as a fraction of median income. This is the same approach to measuring poverty as used by the government in its HBAI publication. Some of the measures analysed in Chapter 3 are also indicators in the government's annual report on its anti-poverty policies, Opportunity for All. ${ }^{6}$ However, it is important to recognise that there are a number of limitations to measuring poverty in this way.

First, the poverty measure is entirely based on income. As well as the possible drawbacks of using HBAI income as a measure of living standards discussed earlier, there are particular issues arising when using this for the further aim of measuring poverty. Policymakers, policy analysts and people in poverty are generally agreed that poverty is multidimensional; these statistics, though, attempt to capture just one dimension - insufficient resources.

Furthermore, none of the measures of poverty presented is explicitly based on an assessment of needs, or what level of income would be adequate to achieve some standard of living. Nor do they take into account public perceptions of what poverty is. This criticism might lead one to view these estimates of poverty as merely another way of summarising the shape of the income distribution that focuses on the individuals with the lowest incomes. However, some studies have suggested that the popular conception of poverty is a relative notion rather than an absolute one. ${ }^{7}$ For single pensioners, at least, one estimate of the cost of an adequate budget produced an answer that was close to 60 per cent of median income AHC. ${ }^{8}$

Even accepting the above limitations, such poverty measures are only informative about the number of poor people. They provide no information on the 'distance' that separates those with incomes below poverty lines from the poverty thresholds, and so contain no information on how poor the poor households are. Nor do they take into account how long people are poor. Yet the 'seriousness' of poverty may be a very important issue and one requiring different policies from those aiming simply to bring people from just below the poverty line across it.

There are, of course, advantages to this way of measuring poverty. For example, the process of producing the eventual statistic is relatively transparent and does not require many subjective decisions on the part of the researcher or government statistician. Furthermore, the measures have been used for many years, they are well understood and it is easy to make comparisons with them over time and across countries.

\footnotetext{
${ }^{6}$ The indicators are the proportions of working-age adults, pensioners and children (all separately) in absolute, relative and persistent poverty. Absolute poverty is measured with reference to median income in 1998/99, relative poverty is measured with reference to contemporaneous median income and persistent poverty is defined as the individual being subject to relatively low income in three out of the last four years. For absolute and relative poverty, incomes are measured both $\mathrm{AHC}$ and $\mathrm{BHC}$, and three poverty lines are defined, corresponding to 50 per cent, 60 per cent and 70 per cent of the relevant median income. For persistent poverty, income is measured BHC only, and the poverty lines correspond to 60 and 70 per cent of the relevant median only.

${ }^{7}$ See Hills (2001 and 2002).

${ }^{8}$ See Goodman, Myck and Shephard (2003, table B1).
} 
Note that the 2004/05 Family Resources Survey contains, for the first time, information on material deprivation, which will be used to develop the material deprivation and low-income 'tier' of the government's new child poverty measure. However, these data have not been available to us to analyse in this Commentary. 


\section{Living standards and inequality}

In this chapter, we analyse what the most recent Households Below Average Income data, from the financial year 2004/05, tell us about living standards and inequality in Great Britain. Section 2.1 examines the features of the entire distribution of income and Section 2.2 explores how average incomes have changed since 1996/97. Section 2.3 shows how income inequality has changed since 1996/97 and Section 2.4 concludes.

\subsection{The income distribution in $2004 / 05$}

Figure 2.1 shows the income distribution in 2004/05. ${ }^{9}$ This graph shows the number of people living in households with different income levels, grouped into $£ 10$ income bands. The height of the bars represents the number of people in each income band. As can be seen, the current distribution is highly skewed, with 65 per cent of individuals having household incomes below the national average. Furthermore, the final bar of the graph shows that 1.5 million individuals (out of a private household population of approximately 57 million individuals) have incomes above $£ 1,100$ a week. The graph also shows that there are approximately half a million individuals whose income is between zero and $£ 10$ a week. Such a discontinuity in the distribution arises because negative incomes have been set to zero. In the data, we observe close to 500,000 individuals who have zero or negative income, which could be due to such things as large self-employment losses or because of various payments that are deducted.

Figure 2.1. The income distribution in 2004/05

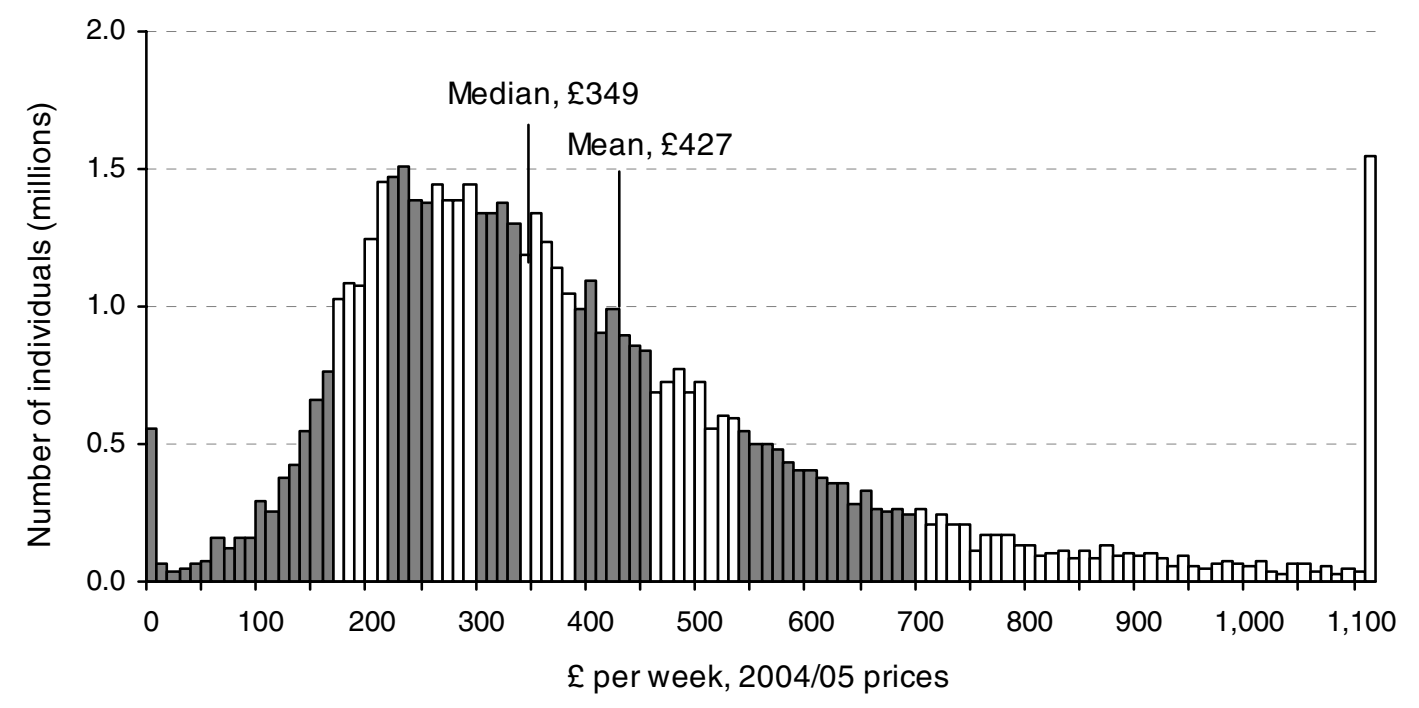

Notes: Incomes have been measured before housing costs have been deducted. The right-most bar represents incomes of over $£ 1,100$.

Source: Authors' calculations using Family Resources Survey, 2004/05.

\footnotetext{
${ }^{9}$ Here, and throughout this chapter, we focus on income before housing costs have been deducted. We will, however, comment where there is any important difference when incomes are instead measured after housing costs.
} 
Figure 2.1 also divides the population into 10 equally sized groups, called decile groups. The first decile group contains the poorest 10 per cent of the population, the second decile group contains the next poorest 10 per cent, and so on. In the graph, the alternately shaded sections represent these different decile groups, and, as can be seen, the distribution is particularly concentrated within a fairly narrow range of incomes in decile groups 2 to 5 . However, as we move further up the income distribution, a widening of the decile group bands can be seen. Note that the tenth decile group band is much wider than is shown in Figure 2.1 because those with incomes greater than $£ 1,100$ are shown together, rather than in $£ 10$ bands.

Many individuals are unaware of their own position in the income distribution. In Table B.1 in Appendix B, we present the monthly income levels for a selection of different family types falling into each income decile group. Researchers at IFS have also developed an interactive income distribution model, which allows individuals to place themselves more precisely in the income distribution on the basis of their household income after adjusting for their household size and composition. The 'Where Do You Fit In?' model is available online at www.ifs.org.uk/wheredoyoufitin.

Figure 2.2 shows how the income distribution has changed between 1996/97 and 2004/05. The first two panels repeat the type of presentation used in Figure 2.1, showing the number of

Figure 2.2. The income distributions in $1996 / 97$ and $2004 / 05$ compared
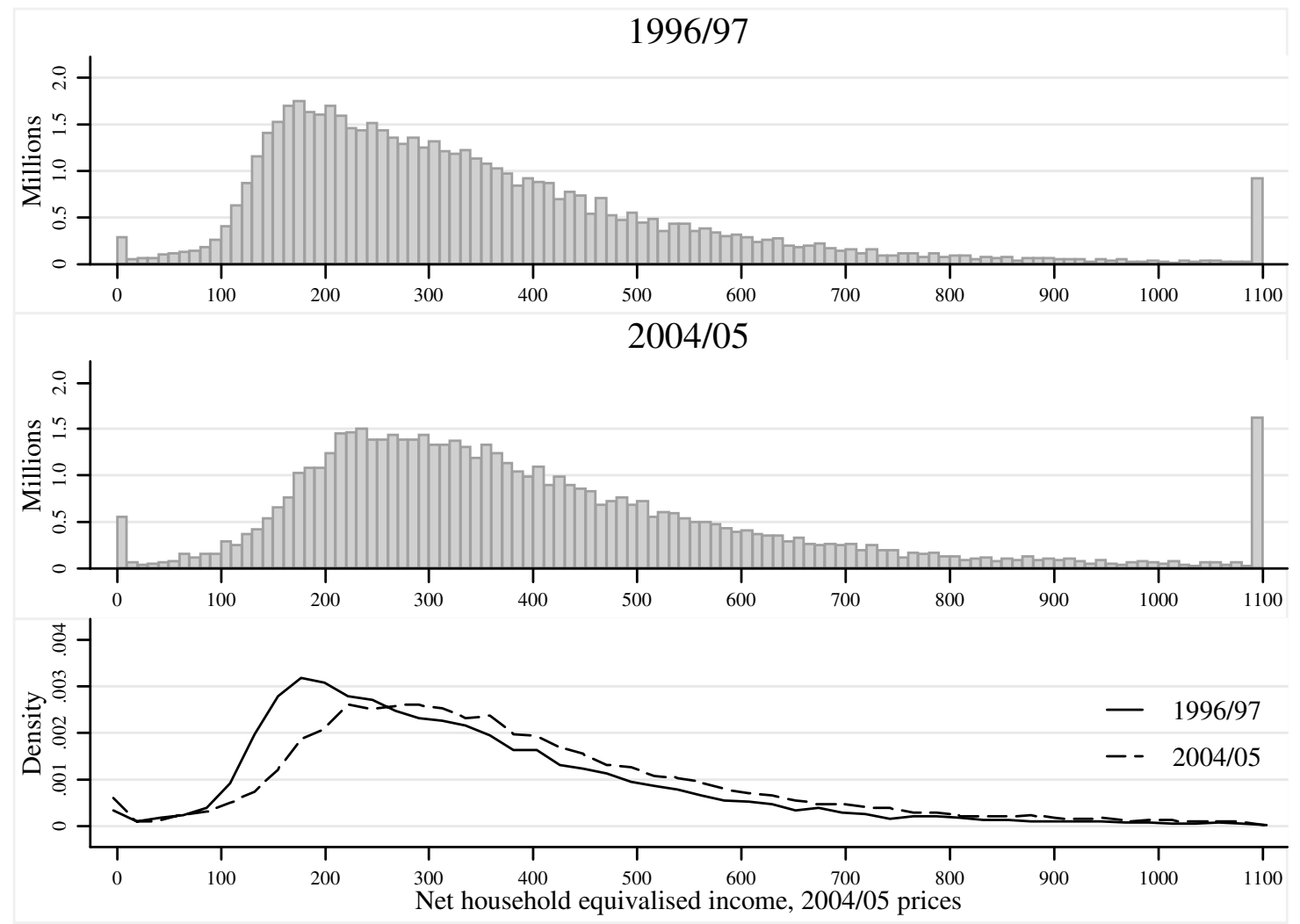

Notes: Incomes have been measured before housing costs have been deducted. The right-most bar in each of the top two panels represents incomes of over $£ 1,100$. The shapes of the distributions in the bottom panel are kernel density estimates, based on the Epanechnikov kernel. These are estimated on the income range $£ 0-£ 1,100$ per week only.

Source: Authors' calculations using Family Resources Survey, 1996/97 and 2004/05. 
people in various income bands in each year, whilst the third panel allows us to see more clearly how the shape of the income distribution has changed over time, by comparing 'kernel density' estimates of the shapes of the distributions - the units for these kernel density estimates are such that the total area under each plotted line is 1 rather than the size of the total population. Looking at this panel, comparing 1996/97 with 2004/05, the shape of the distribution appears to have changed. First, there has been a rightward shift as a result of general growth in households' incomes. Second, the income distribution appears somewhat flatter, with a less pronounced spike at the modal income. ${ }^{10}$

\subsection{Changes in living standards}

This section shows how incomes have changed since 1996/97, both on average and for specific family types. We also point to where important changes have occurred in the extra year of data, i.e. changes between 2003/04 and 2004/05.

\section{Changes in mean and median income}

Recent trends in average income are shown in Figure 2.3. The graph shows that mean income (before housing costs were deducted) was $£ 354$ in 1996/97 and increased to $£ 427$ by 2004/05 (these and all other monetary values in this section are expressed in average 2004/05 prices, and so all differences represent real differences). This corresponds to a real rise of around 21 per cent, or 2.4 per cent on an annualised basis. Similarly, median income increased by 19 per

Figure 2.3. Changes in average real incomes

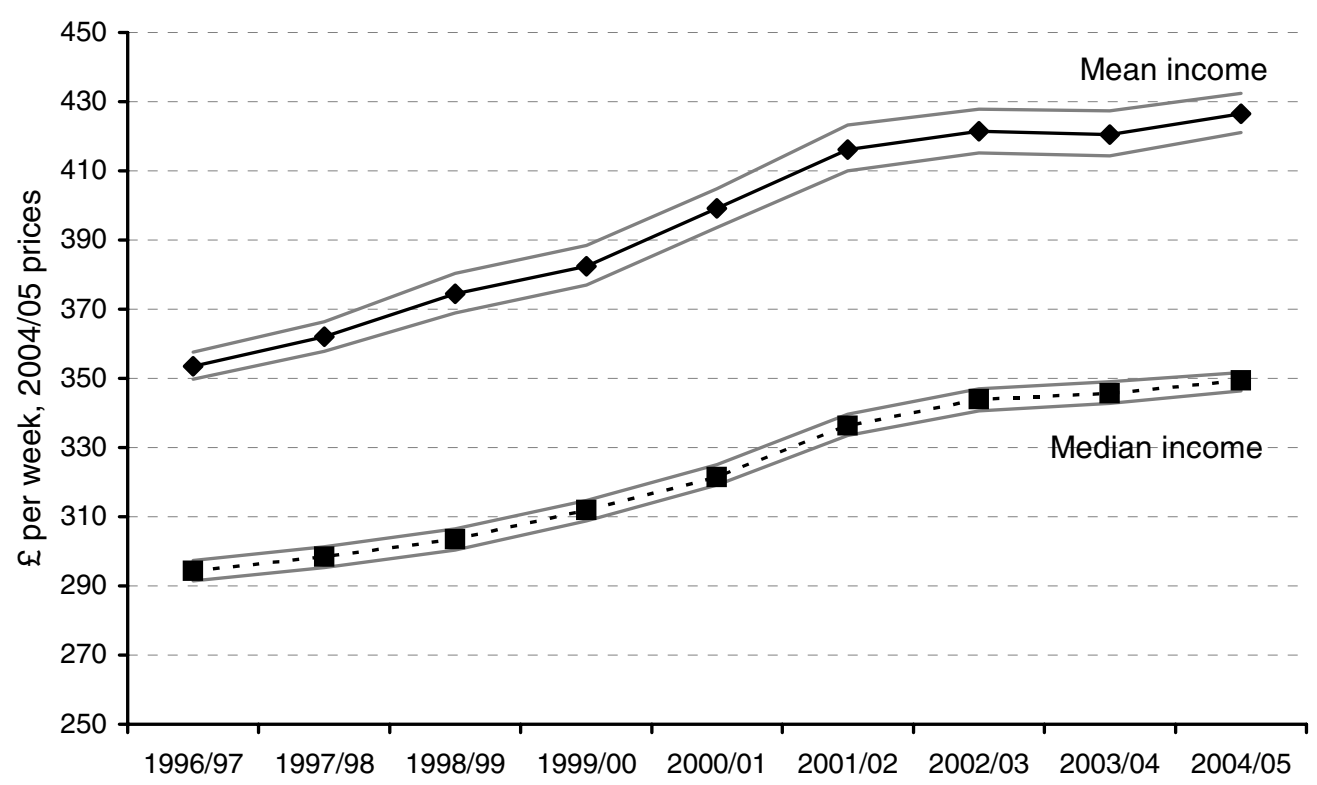

Notes: Incomes have been measured before housing costs have been deducted. Grey lines surrounding mean and median income represent the upper and lower bounds of their respective 95 per cent confidence interval.

Source: Authors' calculations using Family Resources Survey, various years.

\footnotetext{
${ }^{10}$ Modal income refers to the income level possessed by the greatest proportion of the population.
} 
cent (2.2 per cent when annualised), from $£ 294$ to $£ 349 .{ }^{11}$ It must be remembered that when we quote such values as mean and median household income, they are equivalised values and so represent the income that a childless couple would have if they had the same living standard as this household ${ }^{12}$ (see Chapter 1 for more details).

The growth of income is slightly stronger when measured after housing costs than when measured before housing costs: mean and median income increased by 29 per cent and 26 per cent respectively between 1996/97 and 2004/05.

Like every statistic calculated from the HBAI data, the figures given above for mean and median income are estimates based on a sample of households in Britain. Because of this, there will be a confidence interval around each estimate. Figure 2.3 shows the 95 per cent confidence intervals for the mean and median income levels. ${ }^{13}$

Table 2.1. Real income growth and 95 per cent confidence interval

\begin{tabular}{l|ccc|ccc}
\hline & \multicolumn{3}{|c|}{ Mean BHC income } & \multicolumn{3}{c}{ Median BHC income } \\
& Lower & Point & Upper & Lower & Point & Upper \\
\hline $1996 / 97$ & $1.8 \%$ & $3.4 \%$ & $5.1 \%$ & $2.7 \%$ & $4.3 \%$ & $5.6 \%$ \\
$1997 / 98$ & $0.8 \%$ & $2.4 \%$ & $4.1 \%$ & $-0.1 \%$ & $1.4 \%$ & $2.8 \%$ \\
$1998 / 99$ & $1.3 \%$ & $3.4 \%$ & $5.5 \%$ & $0.3 \%$ & $1.7 \%$ & $3.1 \%$ \\
$1999 / 00$ & $0.1 \%$ & $2.1 \%$ & $4.3 \%$ & $1.3 \%$ & $2.8 \%$ & $4.2 \%$ \\
$2000 / 01$ & $2.2 \%$ & $4.4 \%$ & $6.6 \%$ & $1.9 \%$ & $3.1 \%$ & $4.7 \%$ \\
$2001 / 02$ & $2.2 \%$ & $4.2 \%$ & $6.6 \%$ & $3.2 \%$ & $4.6 \%$ & $5.9 \%$ \\
$2002 / 03$ & $-0.9 \%$ & $1.3 \%$ & $3.5 \%$ & $0.9 \%$ & $2.3 \%$ & $3.6 \%$ \\
$2003 / 04$ & $-2.2 \%$ & $-0.2 \%$ & $1.9 \%$ & $-0.6 \%$ & $0.5 \%$ & $1.9 \%$ \\
$2004 / 05$ & $-0.6 \%$ & $1.4 \%$ & $3.5 \%$ & $-0.2 \%$ & $1.1 \%$ & $2.2 \%$ \\
\hline
\end{tabular}

Note: Incomes have been measured before housing costs have been deducted.

Source: Authors' calculations using Family Resources Survey, various years.

Income growth in the last year of the data - between 2003/04 and 2004/05 - was relatively modest, at 1.4 per cent at the mean and 1.1 per cent at the median. These year-on-year changes are not statistically different from zero, nor from the changes in average income in previous recent years (at the 95 per cent level of confidence) (see Table 2.1). It is also interesting to note that the growth of mean income since 2002/03 is not statistically different from zero either. It is therefore clear that the strong year-on-year growth in average living standards seen in the late 1990s and early 2000s has not been repeated over recent years. ${ }^{14}$

\footnotetext{
${ }^{11}$ Mean income is obtained by adding up all incomes and dividing by the total number of people in the population. It gives equal weight to all observations and can therefore be quite sensitive to very low and very high incomes. In contrast, the median is a measure of average that divides the population into two equally sized groups. Half the population have incomes below the median and half have incomes above it. The median is not affected by the presence of very high and very low incomes in the distribution. Because of the differences in these measures of average, it is useful to consider both.

${ }^{12}$ A headline mean equivalised income value in 2004/05 of $£ 427$ would represent an actual income of $£ 632$ for a couple with one child aged 15 and one child aged 7. Similarly, a headline median equivalised income value of $£ 349$ in 2004/05 would represent an actual income of $£ 517$ for the same family.

${ }^{13}$ These, and all other confidence intervals in this chapter, were calculated by bootstrapping the statistic in question. This involves recalculating statistics for each of a series of random samples drawn from the original sample, as a way of approximating the distribution of statistics that would be calculated from different possible samples out of the underlying population. See Davison and Hinkley (1997).

${ }^{14}$ Between 1996/97 and 2001/02, the year-on-year changes in mean income were statistically different from zero; however, from 2002/03 onwards, the year-on-year changes have not been statistically significant. The same is true of
} 
To put this income growth into context, it is necessary to look at what has happened over a longer period. Looking at periods of time defined by political events is one interesting way to do this, although it is important to realise that these periods cover different periods in the economic cycle, and income growth rates are very sensitive to this. Bearing this in mind, Table 2.2 shows that average income growth has been much stronger during Blair's two terms of office than it was under Major, and of a roughly comparable magnitude to that experienced under Thatcher. However, the pattern of income growth has not been the same across Blair's two terms. Annualised mean income growth was 1.3 percentage points lower during Blair's second term than during his first, but median income growth was similar in both terms. In fact, Blair's second term was the only period in which annualised median income growth (2.1 per cent) exceeded mean annualised income growth (1.7 per cent), which seems to be due to the fact that, during this period, the bottom half of the income distribution saw bigger average increases in income than the top half (see Figure 2.7 later).

Table 2.2. Annualised real average income growth

\begin{tabular}{l|cc}
\hline & Mean & Median \\
\hline Blair (1996/97 - 2004/05) & $2.4 \%$ & $2.2 \%$ \\
Of which: & $3.0 \%$ & $2.2 \%$ \\
Blair I (1996/97-2000/01) & $1.7 \%$ & $2.1 \%$ \\
Blair II (2000/01-2004/05) & & \\
& $2.1 \%$ & $1.6 \%$ \\
Conservatives (1979-1996/97) & & \\
Of which: & $0.8 \%$ & $0.8 \%$ \\
Major (1990-1996/97) & $2.9 \%$ & $2.1 \%$ \\
Thatcher $(1979-1990)$ &
\end{tabular}

Note: Incomes have been measured before housing costs have been deducted.

Source: Authors' calculations using Family Resources Survey and Family Expenditure Survey, various years.

\section{Changes in average incomes of different family types}

Different family types have experienced different growth in their household income since 1996/97. In Table 2.3, we present income growth and average income levels decomposed by family type. The table shows that out of all the family types, couples without children had the highest household equivalised income on average in 2004/05 (a mean income of £531 per week), followed by singles without children (income of $£ 447$ per week). Lone parents and single pensioners had the lowest mean weekly incomes ( $£ 283$ and $£ 334$ respectively). 
Table 2.3. Annualised income growth (1996/97 - 2004/05) and average income levels, by family type

\begin{tabular}{l|cc|cc}
\hline & \multicolumn{2}{|c|}{ Mean BHC income } & \multicolumn{2}{c}{ Median BHC income } \\
& Growth & 2004/05 level & Growth & 2004/05 level \\
\hline Lone parents & $3.3 \%$ & $£ 283$ & $3.4 \%$ & $£ 252$ \\
Single pensioners & $3.0 \%$ & $£ 334$ & $3.2 \%$ & $£ 291$ \\
Pensioner couples & $2.2 \%$ & $£ 367$ & $2.3 \%$ & $£ 296$ \\
Couples with children & $2.5 \%$ & $£ 423$ & $2.1 \%$ & $£ 347$ \\
Singles without children & $2.4 \%$ & $£ 447$ & $1.8 \%$ & $£ 371$ \\
Couples without children & $2.0 \%$ & $£ 531$ & $1.8 \%$ & $£ 458$ \\
All & $2.4 \%$ & $£ 427$ & $2.2 \%$ & $£ 349$ \\
\hline
\end{tabular}

Notes: Incomes have been measured before housing costs have been deducted. Family types have been ordered in rows by mean $\mathrm{BHC}$ income.

Source: Authors' calculations using Family Resources Survey, various years.

Table 2.4 shows the incomes of the same family types relative to the mean and median income in both 1996/97 and 2004/05. It emphasises the fact that although single pensioners and lone parents were the poorest families on average in 1996/97, and remained so in 2004/05, they have been catching up in recent years. Their income growth has exceeded the national average since 1996/97 (see Table 2.3) and their incomes have moved closer to the mean and median, in part reflecting the significant financial resources directed to these groups by the government (see Adam and Wakefield (2005)). ${ }^{15}$

Although changes over the last year for each family type are not shown in Table 2.3, it should be noted that pensioner incomes have seen particularly strong growth in the last year (i.e. between 2003/04 and 2004/05). We return to the issue of pensioner incomes in Chapter 3 when we discuss recent trends in pensioner poverty.

Table 2.4. Income as a proportion of mean and median income in 1996/97 and $2004 / 05$, by family type

\begin{tabular}{l|cc|cc}
\hline & \multicolumn{2}{|c|}{ Mean BHC income } & \multicolumn{2}{c}{ Median BHC income } \\
& $\mathbf{1 9 9 6 / 9 7}$ & $\mathbf{2 0 0 4 / 0 5}$ & $\mathbf{1 9 9 6 / 9 7}$ & $\mathbf{2 0 0 4 / 0 5}$ \\
\hline Lone parents & 0.61 & 0.66 & 0.67 & 0.72 \\
Single pensioners & 0.74 & 0.78 & 0.77 & 0.83 \\
Pensioner couples & 0.87 & 0.86 & 0.83 & 0.85 \\
Couples with children & 0.98 & 0.99 & 1.03 & 0.99 \\
Singles without children & 1.04 & 1.05 & 1.07 & 1.06 \\
Couples without children & 1.28 & 1.24 & 1.34 & 1.31 \\
All & & & & $£ 394$ \\
\hline
\end{tabular}

Notes: Incomes have been measured before housing costs have been deducted. Family types have been ordered in rows by proportion of mean $\mathrm{BHC}$ income.

Source: Authors' calculations using Family Resources Survey, various years.

\footnotetext{
${ }^{15}$ Table B.2 in Appendix B presents annualised income growth rates by these family types on an AHC basis.
} 


\section{Changes in average incomes by region}

As Tables 2.5 and 2.6 show, average income varies markedly by region: it is highest on average in London (with a mean income of $£ 539$, measured BHC), the South-East (£483) and East Anglia (£444), and lowest in the North (£359), Wales (£366) and Yorkshire \& Humberside (£368). ${ }^{16}$

However, regional variation in prices is likely to mean that differences in living standards across regions are less marked than these numbers suggest. An easy way to see this is to compare the regional variations in incomes measured BHC and AHC, since housing costs are almost certainly one of the key forces driving differences in the cost of living across regions. When income is measured BHC, median incomes in the North are 0.79 times their level in London. However, the same ratio rises to 0.88 when income is measured AHC. Therefore, failing to account for the large differences in housing costs across regions implies that the regional variation in real living standards is higher than a measure less biased by regional price variation would suggest.

Figure 2.4. Change in median AHC income across regions, 1996/97 - 2004/05
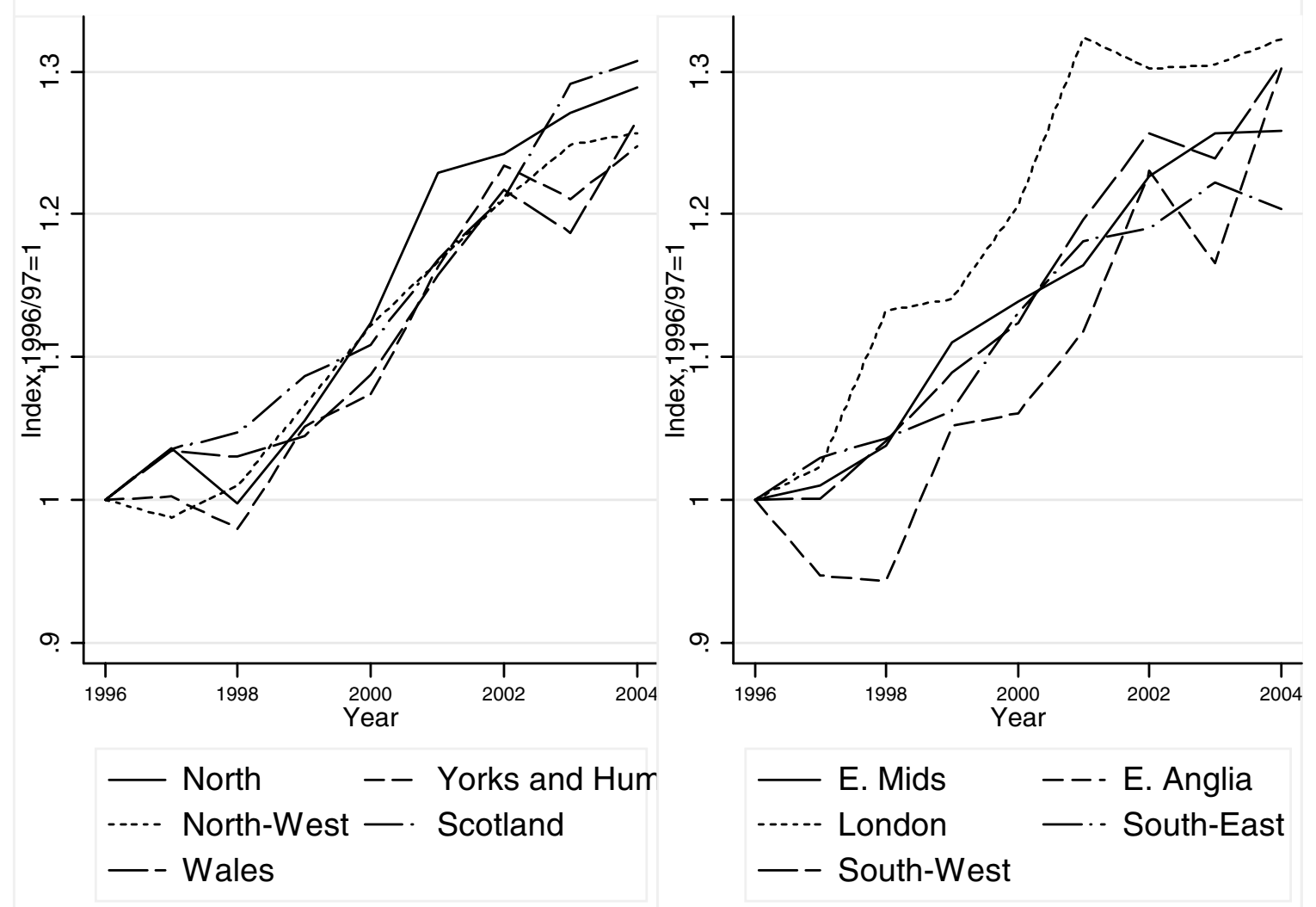

Note: Years are financial years (e.g. 1996 refers to financial year 1996/97).

Source: Authors' calculations using Family Resources Survey, various years.

\footnotetext{
${ }^{16}$ In this distribution, Northern Ireland has a similarly low average income level (£372).
} 
Table 2.5. Annualised income growth (1996/97 - 2004/05) and average income levels, by region and relative to London: BHC income

\begin{tabular}{|c|c|c|c|c|c|c|}
\hline & Growth & $\begin{array}{c}2004 / 05 \\
\text { level }\end{array}$ & $\begin{array}{l}\text { ome } \\
\text { Level } \\
\text { relative } \\
\text { to } \\
\text { London }\end{array}$ & Growth & $\begin{array}{c}2004 / 05 \\
\text { level }\end{array}$ & $\begin{array}{c}\text { come } \\
\text { Level } \\
\text { relative } \\
\text { to } \\
\text { London }\end{array}$ \\
\hline North & $1.5 \%$ & $£ 359$ & 0.67 & $2.1 \%$ & $£ 309$ & 0.79 \\
\hline Wales & $2.0 \%$ & $£ 366$ & 0.68 & $2.0 \%$ & $£ 318$ & 0.82 \\
\hline Yorkshire and Humberside & $1.7 \%$ & $£ 368$ & 0.68 & $2.0 \%$ & $£ 322$ & 0.83 \\
\hline Northern Ireland & $\mathrm{n} / \mathrm{a}$ & $£ 372$ & 0.69 & $\mathrm{n} / \mathrm{a}$ & $£ 327$ & 0.84 \\
\hline West Midlands & $1.8 \%$ & $£ 377$ & 0.70 & $1.7 \%$ & $£ 325$ & 0.84 \\
\hline East Midlands & $2.2 \%$ & $£ 388$ & 0.72 & $2.1 \%$ & $£ 330$ & 0.85 \\
\hline North-West & $2.4 \%$ & $£ 391$ & 0.73 & $2.3 \%$ & $£ 332$ & 0.85 \\
\hline Scotland & $2.5 \%$ & $£ 397$ & 0.74 & $2.6 \%$ & $£ 349$ & 0.90 \\
\hline South-West & $2.9 \%$ & $£ 424$ & 0.79 & $2.5 \%$ & $£ 353$ & 0.91 \\
\hline East Anglia & $2.5 \%$ & $£ 444$ & 0.82 & $2.7 \%$ & $£ 377$ & 0.97 \\
\hline South-East & $1.9 \%$ & $£ 483$ & 0.90 & $1.7 \%$ & $£ 393$ & 1.01 \\
\hline London & $3.7 \%$ & $£ 539$ & 1.00 & $3.0 \%$ & $£ 389$ & 1.00 \\
\hline All (Great Britain) & $2.4 \%$ & $£ 427$ & & $2.2 \%$ & $£ 349$ & \\
\hline
\end{tabular}

Notes: Incomes have been measured before housing costs have been deducted. Regions have been ordered in rows by mean BHC income.

Source: Authors' calculations using Family Resources Survey, various years. Note that Northern Ireland figures are not available for 1996/97. Northern Ireland incomes have not been 'SPI adjusted' (see Chapter 1 for information about the SPI adjustment).

Table 2.6. Annualised income growth (1996/97 - 2004/05) and average income levels, by region and relative to London: AHC income

\begin{tabular}{|c|c|c|c|c|c|c|}
\hline & \multicolumn{3}{|c|}{\begin{tabular}{ccc}
\multicolumn{2}{c}{ Mean AHC income } \\
& $\begin{array}{c}\text { Level } \\
\text { relative } \\
\text { to }\end{array}$ \\
Growth & $\begin{array}{c}\text { 2004/05 } \\
\text { level }\end{array}$ & London
\end{tabular}} & \multicolumn{3}{|c|}{\begin{tabular}{ccc}
\multicolumn{2}{c}{ Median AHC income } \\
& $\begin{array}{c}\text { Level } \\
\text { relative } \\
\text { to }\end{array}$ \\
Growth & $\begin{array}{c}\text { to } \\
\text { level }\end{array}$ \\
London
\end{tabular}} \\
\hline North & $2.4 \%$ & $£ 321$ & 0.70 & $3.2 \%$ & $£ 279$ & 0.88 \\
\hline Yorkshire and Humberside & $2.5 \%$ & $£ 329$ & 0.72 & $2.8 \%$ & $£ 286$ & 0.90 \\
\hline Wales & $2.9 \%$ & $£ 331$ & 0.72 & $3.0 \%$ & $£ 287$ & 0.90 \\
\hline West Midlands & $2.6 \%$ & $£ 336$ & 0.74 & $2.6 \%$ & $£ 288$ & 0.91 \\
\hline Northern Ireland & $\mathrm{n} / \mathrm{a}$ & $£ 341$ & 0.75 & $\mathrm{n} / \mathrm{a}$ & $£ 301$ & 0.95 \\
\hline East Midlands & $2.9 \%$ & $£ 346$ & 0.76 & $2.9 \%$ & $£ 295$ & 0.93 \\
\hline North-West & $3.3 \%$ & $£ 348$ & 0.76 & $2.9 \%$ & $£ 294$ & 0.92 \\
\hline Scotland & $3.3 \%$ & $£ 356$ & 0.78 & $3.4 \%$ & $£ 313$ & 0.98 \\
\hline South-West & $3.8 \%$ & $£ 373$ & 0.82 & $3.4 \%$ & $£ 310$ & 0.97 \\
\hline East Anglia & $3.3 \%$ & $£ 393$ & 0.86 & $3.4 \%$ & $£ 335$ & 1.05 \\
\hline South-East & $2.7 \%$ & $£ 421$ & 0.92 & $2.3 \%$ & $£ 337$ & 1.06 \\
\hline London & $4.5 \%$ & $£ 457$ & 1.00 & $3.6 \%$ & $£ 318$ & 1.00 \\
\hline All (Great Britain) & $3.2 \%$ & $£ 375$ & & $2.9 \%$ & $£ 304$ & \\
\hline
\end{tabular}

Notes: Incomes have been measured after housing costs have been deducted. Regions have been ordered in rows by mean $\mathrm{AHC}$ income.

Source: Authors' calculations using Family Resources Survey, various years. Note that Northern Ireland figures are not available for 1996/97. Northern Ireland incomes have not been 'SPI adjusted' (see Chapter 1 for information about the SPI adjustment). 
Figure 2.4 shows that median AHC income growth has been fairly even across regions, suggesting that broad regional differences in average living standards have not changed much since 1996/97. The one exception to this is London, where even after housing costs are taken into account, the growth in median income has been notably stronger than that in other regions.

\subsection{What has happened to income inequality?}

As well as considering what has happened to average income, it is also interesting to consider what has happened to income inequality. Throughout this Commentary, we will be adopting a relative notion of inequality in our discussion of income inequality. This means that should all incomes increase or decrease by the same proportional amount, we would conclude that income inequality had remained unchanged.

Whilst many people are interested in what has happened to inequality over time, and in particular to the 'gap between the rich and the poor', it is important to realise that a given level of income inequality could pertain in a very egalitarian society, or in a very inegalitarian one, depending on whether individuals keep the same position in the income scale forever, or whether individuals move position in the income scale every year (so-called income mobility'). Although in this Commentary we consider what has happened to the level of income inequality in recent years, we are not able to analyse from these data how income mobility has changed. For studies that do this, see Blundell and Preston (1998), Dickens (2000) and Jarvis and Jenkins (1998).

\section{Income changes by quintile group}

One simple way to show how inequality has changed across the population is to consider average real income growth by quintile group (each quintile group contains 20 per cent of the population, or around 11 million individuals). We begin in Figure 2.5 by comparing how incomes have changed in these different quintile groups between 2003/04 and 2004/05.

The graph demonstrates that the mean income growth of 1.4 per cent during this time was not shared evenly across the income scale but was slightly stronger in the first and second quintile groups than in the third, fourth and fifth quintiles. As none of these differences are statistically different from one another, there has been little change in overall income inequality over the past year. It is not surprising that the poorest quintile groups saw the largest gains over the past year, as the pension credit was increased in line with earnings and the child tax credit was increased by an even greater proportion, and as large numbers of pensioners and families with children are found in the lowest two quintiles.

Figure 2.6 shows the pattern of income growth by quintile under Labour since 1996/97. It also sets out for comparison how incomes have grown by quintile group under the previous governments of Margaret Thatcher and John Major. Figure 2.7 decomposes the experience under Blair into Labour's two terms of office. Income growth has been broadly similar across quintiles taking the period since $1996 / 97$ as a whole, though there was slightly more growth in the poorer quintiles than in the richer ones during Labour's second term. A direct consequence of this is that the overall level of income inequality has changed little over the 
Figure 2.5. Real income growth by quintile group, 2003/04 - 2004/05

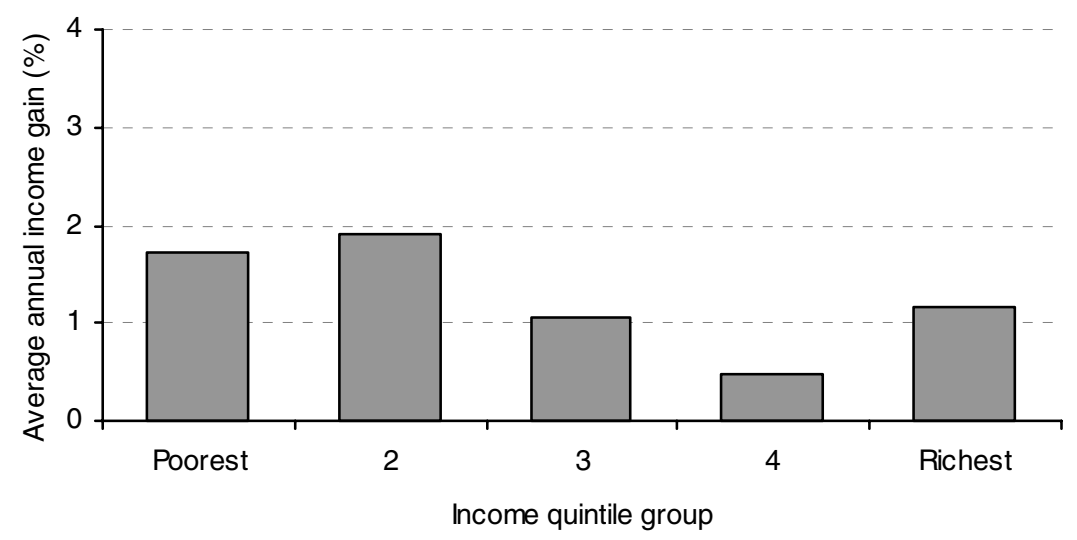

Notes: The averages in each quintile group correspond to the midpoints, i.e. the $10^{\text {th }}, 30^{\text {th }}, 50^{\text {th }}, 70^{\text {th }}$ and $90^{\text {th }}$ percentile points of the income distribution. Incomes have been measured before housing costs have been deducted. Source: Authors' calculations using Family Resources Survey, various years.

Figure 2.6. Real income growth by quintile group

Blair: 1996/97 - 2004/05

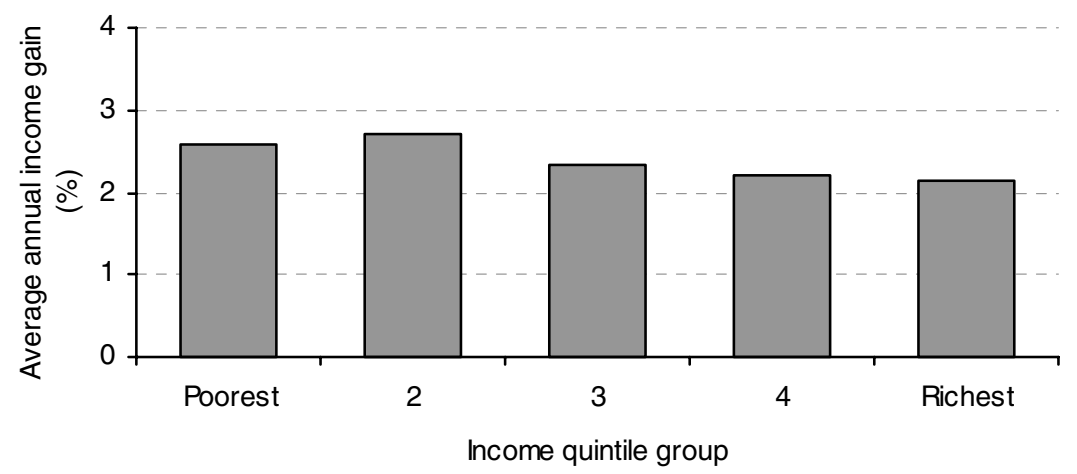

Major: 1990 - 1996/97

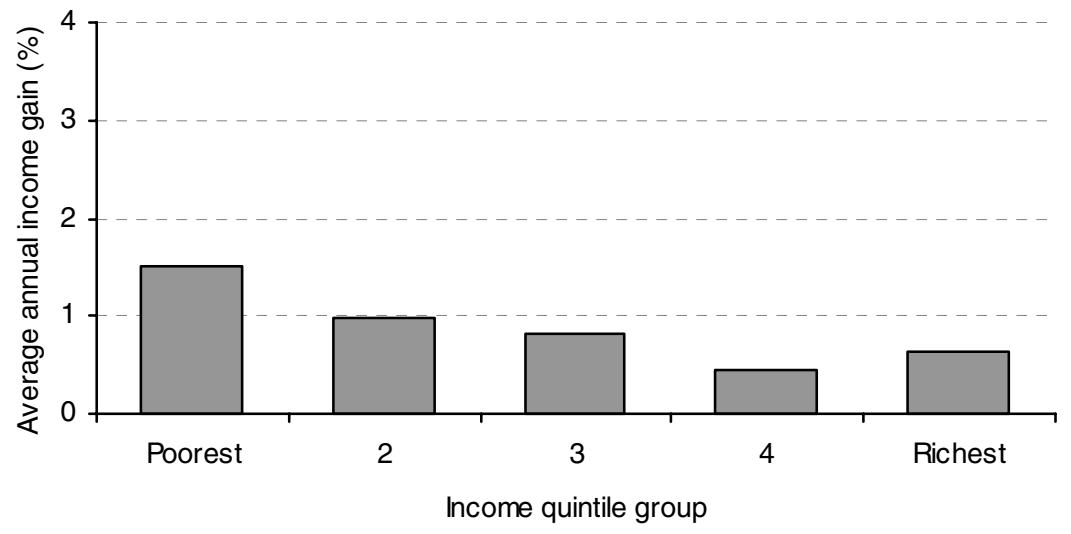

Figure 2.6 continues on the next page 
Figure 2.6 continued

Thatcher: $1979-1990$

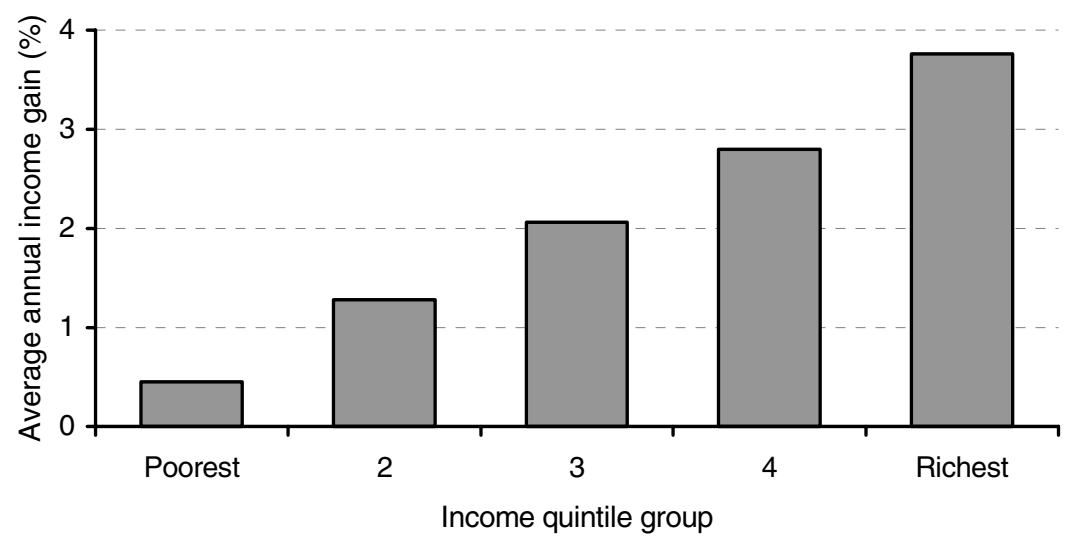

Notes: The averages in each quintile group correspond to the midpoints, i.e. the $10^{\text {th }}, 30^{\text {th }}, 50^{\text {th }}, 70^{\text {th }}$ and $90^{\text {th }}$ percentile points of the income distribution. Incomes have been measured before housing costs have been deducted. Source: Authors' calculations using Family Resources Survey and Family Expenditure Survey, various years.

Figure 2.7. Real income growth by quintile group in Labour's two terms Blair I: 1996/97 - 2000/01

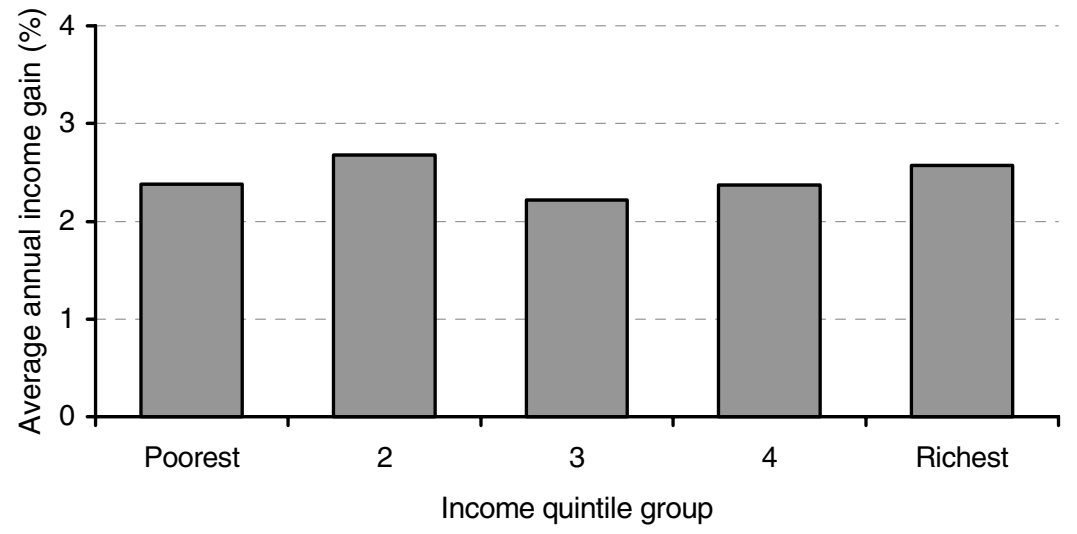

Blair II: 2000/01 - 2004/05

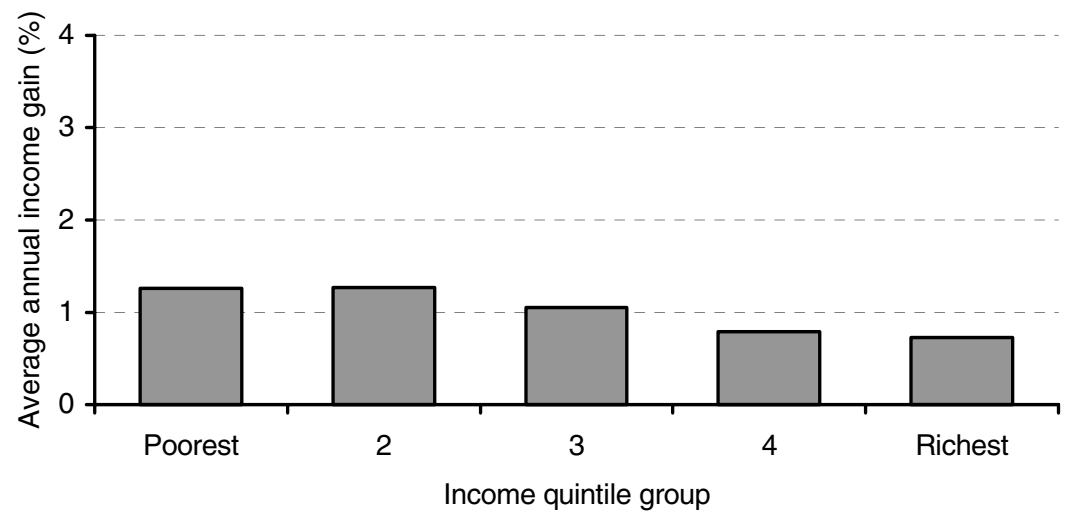

Notes: The averages in each quintile group correspond to the midpoints, i.e. the $10^{\text {th }}, 30^{\text {th }}, 50^{\text {th }}, 70^{\text {th }}$ and $90^{\text {th }}$ percentile points of the income distribution. Incomes have been measured before housing costs have been deducted. Source: Authors' calculations using Family Resources Survey, various years. 
period since 1996/97 as a whole (for more on summary measures of income inequality, see below). This pattern of 'overall little change' is in contrast to the steep rise in inequality under Thatcher and the modest fall in income inequality under Major.

\section{A more detailed look at the changing income distribution}

While Figures 2.5 to 2.7 give us a reasonable impression of how incomes have been changing across much of the distribution, they do mask the changes at the extremes. In Figure 2.8, we show how incomes have changed right across the distribution between 1996/97 and 2004/05 including those individuals at the $99^{\text {th }}$ percentile point. This graph is similar to the Blair chart in Figure 2.6, except that rather than presenting how incomes have changed in different quintile groups, we instead consider income growth at 99 percentile points in the income distribution. ${ }^{17}$ The differently shaded sections again correspond to the different income decile groups. To place the changes in a historical context, we also show how this income growth compares with what was observed between 1979 and 1996/97 under the Conservative governments of Margaret Thatcher and John Major, as illustrated by the superimposed line.

Figure 2.8. Real income growth by percentile point, 1996/97 - 2004/05

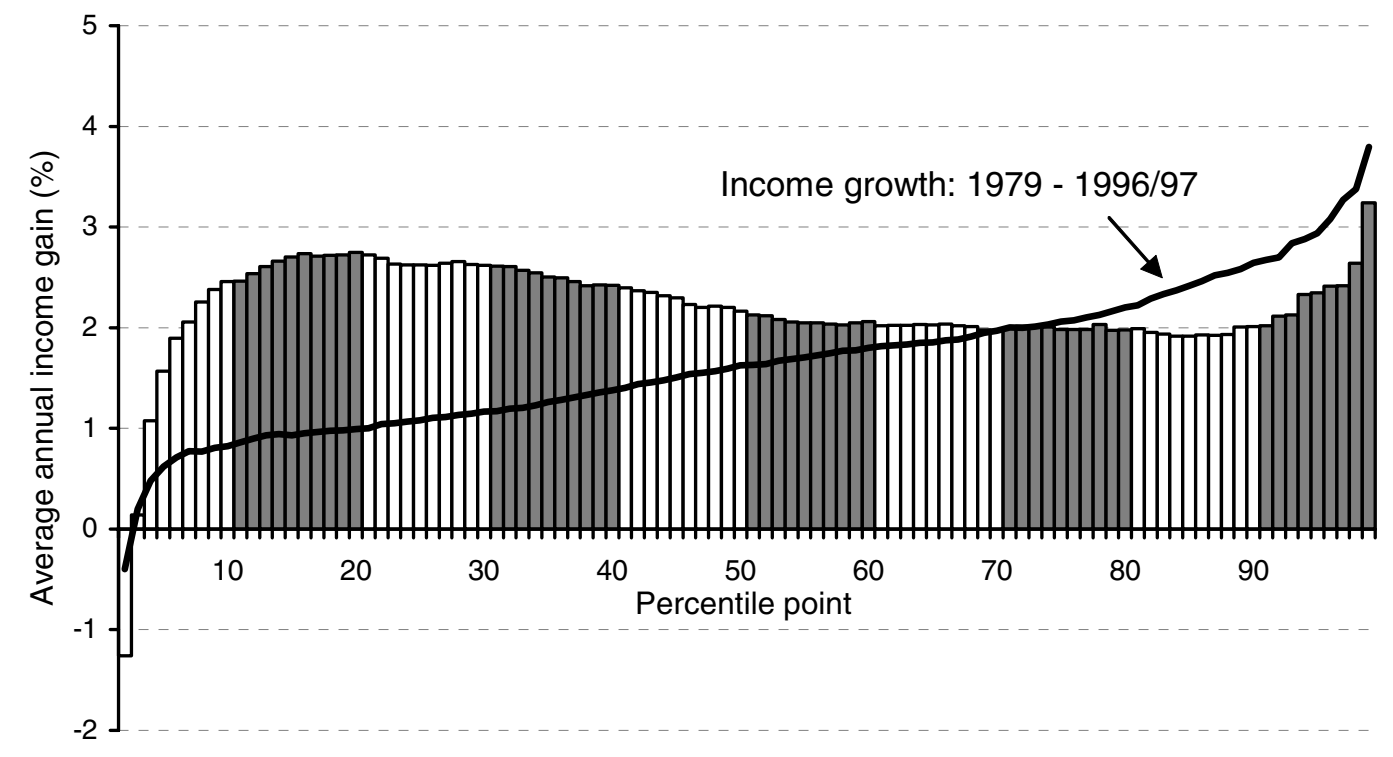

Notes: The change in income at the $1^{\text {st }}$ percentile is not shown on this graph (see footnote 17). Incomes have been measured before housing costs have been deducted.

Source: Authors' calculations using Family Resources Survey and Family Expenditure Survey, various years.

Looking at the main bulk of the income distribution, we see that between about the $15^{\text {th }}$ percentile point and the $90^{\text {th }}$ percentile point, it is generally the lower parts of the distribution that have gained most over the period 1996/97 to 2004/05; by itself, this would be consistent with falling inequality. Below the $15^{\text {th }}$ percentile point, however, income growth is progressively lower the lower the income percentile, with real income falls at the very lowest part of the income distribution. Beyond the $90^{\text {th }}$ percentile point, income growth is generally

\footnotetext{
${ }^{17}$ In Figure 2.8, growth at the $1^{\text {st }}$ percentile point has not been shown, in order to maintain a reasonable scale for the graph. However, at -16.2 per cent, it is certainly very different from anything observed elsewhere in the distribution.
} 
increasing in income, with a spike at the $99^{\text {th }}$ percentile point. In previous years, we have pointed to the growth in the very top incomes as one driver of continued income inequality growth in recent years (see Brewer et al. (2004 and 2005)). However, income changes at the very top of the scale have been slower in the last two years than in preceding years. This is consistent with a pattern of modestly rising income inequality in Labour's first term, followed by an offsetting modest fall in the second term.

The superimposed line in Figure 2.8 shows that almost without exception over the period 1979 to 1996/97, income growth was increasing in the level of income. There would be a much steeper upward gradient in income growth by income if we were to look at the period 1979 to 1990 in isolation, a time of rising income inequality, as we have done in previous years (see Brewer et al. (2004 and 2005). However, as was clear from Figure 2.6, the period between 1990 and 1996/97 under the premiership of John Major saw slightly greater income growth in the lower half of the distribution, leading to a slightly offsetting fall in income inequality over that period. This implies that whilst the lower income deciles have fared considerably better, and the top deciles slightly worse, under Labour since 1996/97 than they did between 1979 and 1990, these differences are much less stark when one compares the experience under Labour with the entire period of Conservative governments between 1979 and 1996/97.

While Figure 2.8 gives us a very detailed impression of how incomes have been evolving, it can prove very useful to construct some summary measures. This is particularly helpful if we want to track how inequality has evolved through the tenure of the current and preceding governments. Various measures are discussed in the next subsection.

\section{Summary measures of inequality}

Income inequality is popularly defined as the gap between 'rich' and 'poor'. However, this definition reveals the entirely subjective nature of any measure of income inequality, since who are the 'rich' and who are the 'poor'? Choosing whose incomes to compare and what weights to attach to various differences in income is very important in determining how one summarises income inequality within a society. To take a hypothetical example, think of a society made up of 100 people, 98 of whom have identical incomes of $£ 100$; the $99^{\text {th }}$ person has income of $£ 1,000$ and the remaining one has nothing. Income inequality in this society would be very large indeed if one just compared the very richest and the very poorest individuals, but this society would look very equal if one compared the $90^{\text {th }}$ percentile point with the $10^{\text {th }}$ percentile point.

There are a wide range of measures available to define income inequality, based on different definitions of income inequality. Figure 2.9 shows the path of a selection of inequality measures since 1996/97, indexed so as to equal 1 in 1996/97 (90/10 ratio, mean log deviation, the Gini coefficient and the Atkinson inequality measure). The 90/10 ratio is the simplest of these measures, as it is just the ratio of the income of the household at the $90^{\text {th }}$ percentile point to that of the household at the $10^{\text {th }}$ percentile point. Mean log deviation (MLD) measures the expected percentage difference between the income of a randomly selected individual and overall mean income. The Gini coefficient is a popular measure of income inequality; it can be interpreted as the expected proportional income gap between two individuals randomly selected from the population (normalised by twice the mean). A Gini coefficient value of 0 
corresponds to the absence of inequality, so that having adjusted for household size and composition, all individuals have the same household income. In contrast, a value of 1 corresponds to inequality in its most extreme form, with a single individual having command over the entire income in the economy. These measures are discussed in detail in Appendix C.

Figure 2.9 shows that income inequality as measured by the Gini coefficient and MLD rose throughout the later 1990s, rising most strongly according to MLD. ${ }^{18}$ However, both have since fallen back to levels just above that seen in 1996/97. The 90/10 ratio has seen a slightly different pattern, as it stayed broadly stable until 2000/01, after which it has fallen and is now at a lower level than it was in 1996/97. Seen together with Figure 2.8, one could conclude that it is the difference between income growth at the very bottom and very top of the distribution that is driving the slight rise in income inequality since 1996/97 as measured by the Gini coefficient and MLD. Stronger growth in the bottom deciles than the top deciles has led to a fall in income inequality over the same period as measured by the 90/10 ratio.

Figure 2.9. Summary measures of income inequality, 1996/97 - 2004/05

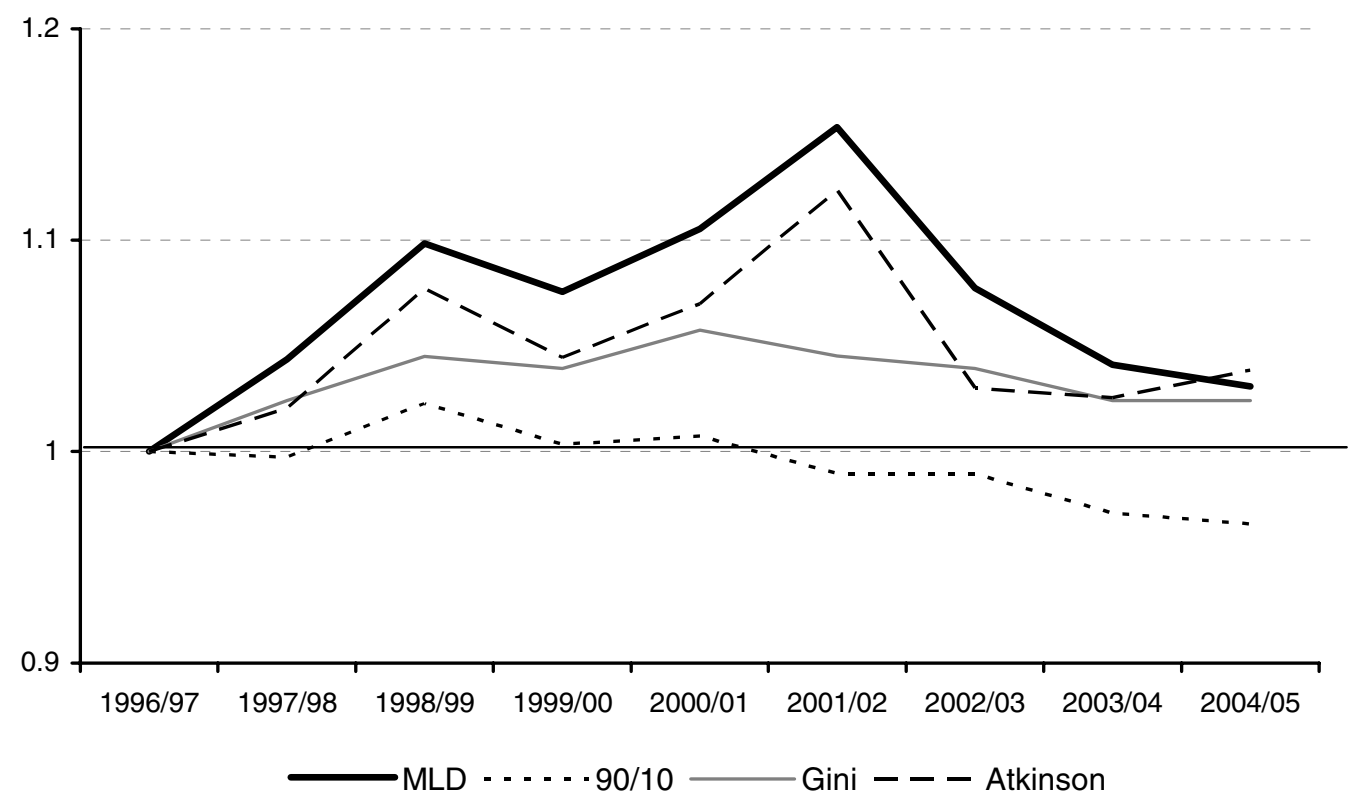

Notes: Measures have been calculated using incomes before housing costs have been deducted. The Atkinson inequality measure is shown for an inequality aversion parameter, $\varepsilon$, of 1.5 (see the text for details). Source: Authors' calculations using Family Resources Survey, various years.

Another way to look at inequality is to use what is called a social welfare function to judge how society's welfare is affected by trends in income growth across the entire income distribution. One measure that makes use of a social welfare function is the Atkinson inequality measure (AIM), which allows one to choose a value for society's aversion to inequality, $\varepsilon$. This parameter defines the amount, $£ x$, that society considers it necessary to give to a 'poor' person, having taken $£ 100$ from a 'rich' person, in order to keep overall social welfare the same. $\varepsilon$ is determined by the formula $2 \varepsilon=100 / x$; see Atkinson (1983) for more

\footnotetext{
${ }^{18}$ When incomes are measured after housing costs, the overall increase is smaller and is not statistically significant.
} 
details. Note that the lower the value of $x$ (and the higher the value of $\varepsilon$ ), the more inequalityaverse is the society. The AIM for $x=33(\varepsilon=1.5)$ is shown in Figure 2.9, together with the other summary measures of inequality (Figure C.2 in Appendix C shows the evolution of the AIM under different values of $\varepsilon$ ). It appears that this measure of the AIM follows a pattern over time very similar to that of the Gini coefficient and MLD, suggesting that taking into account how inequality might have affected societal welfare does not materially change how we might view trends in income inequality over recent years.

We have seen that how one assesses changes in income inequality over recent years depends on the specific way in which one chooses to summarise income inequality. One could say that the net effect of eight years of Labour government is to leave inequality either slightly higher or slightly lower. Despite this, the magnitudes of the differences suggest that whichever measure one chooses to use, income inequality is probably not substantially different now from its level in 1996/97. However, inequality still remains at historically high levels. Indeed, in 2000/01, inequality as measured by the Gini coefficient was at its highest level since at least 1961. Figure 2.10 shows the evolution of the Gini from 1979 to 2004/05. ${ }^{19}$

Figure 2.10. The Gini coefficient (net income) since 1979

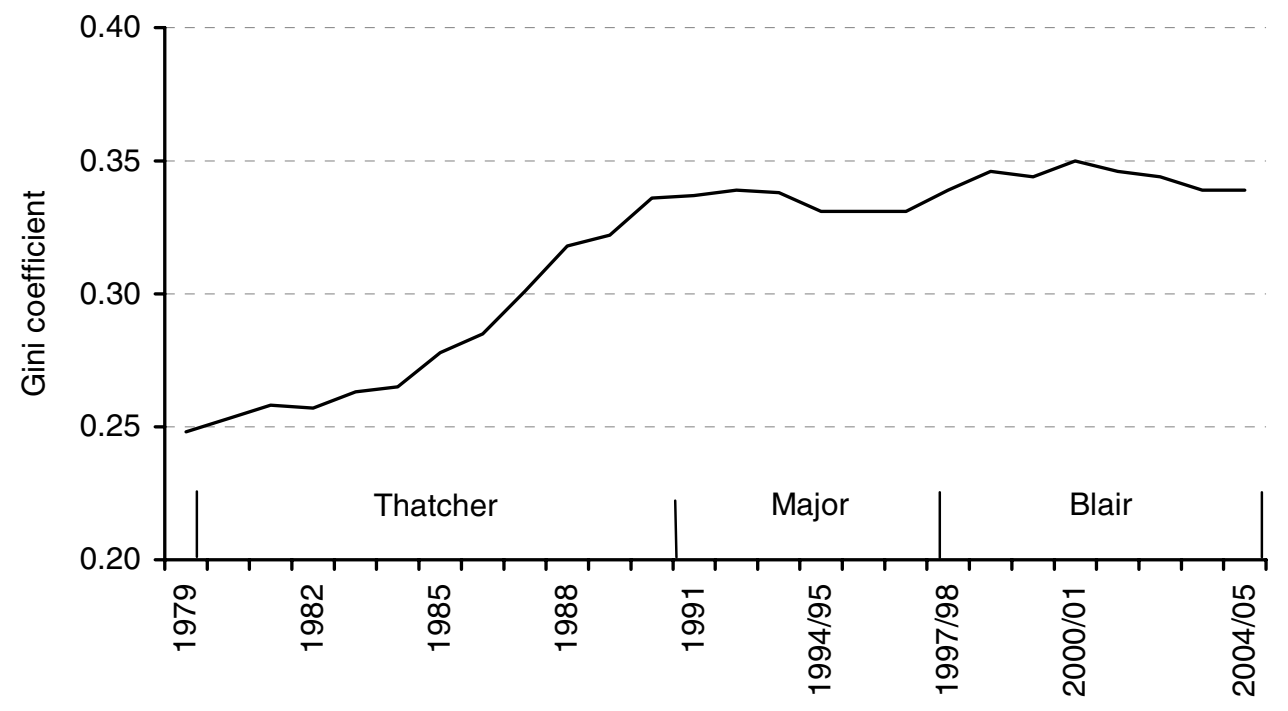

Note: The Gini coefficient has been calculated using incomes before housing costs have been deducted. Source: Authors' calculations using Family Expenditure Survey and Family Resources Survey, various years.

\section{Gross income inequality}

Although income inequality is currently at effectively the same level as it was in 1996/97, the tax and benefit reforms introduced by the Labour government over this time have been strongly redistributive, favouring lower-income families, especially those with children and older people. Previous work at IFS modelling the impact of these reforms on the income distribution has suggested that without them, the distribution of income would have continued

\footnotetext{
${ }^{19}$ A graph of the evolution of the Gini coefficient since 1961 can be found in Goodman and Shephard (2002, figure 5).
} 
to become considerably more unequal (see, for example, Brewer et al. (2005), Clark and Leicester (2004) and Adam and Wakefield (2005)).

Figure 2.11 shows the evolution of inequality, as measured by the Gini coefficient, in 'gross incomes' - that is, incomes from private sources (primarily from earnings, self-employment, investments and private pensions) before the deduction of any direct taxes and before benefits have been added. Gross income inequality appears to exhibit the same trends over time as net income inequality, also shown on the graph: they both rise slightly over Labour's first term of office and fall slightly during Labour's second term (though neither of these trends is statistically significant).

Figure 2.11. The Gini coefficient for gross and net incomes, 1996/97 - 2004/05

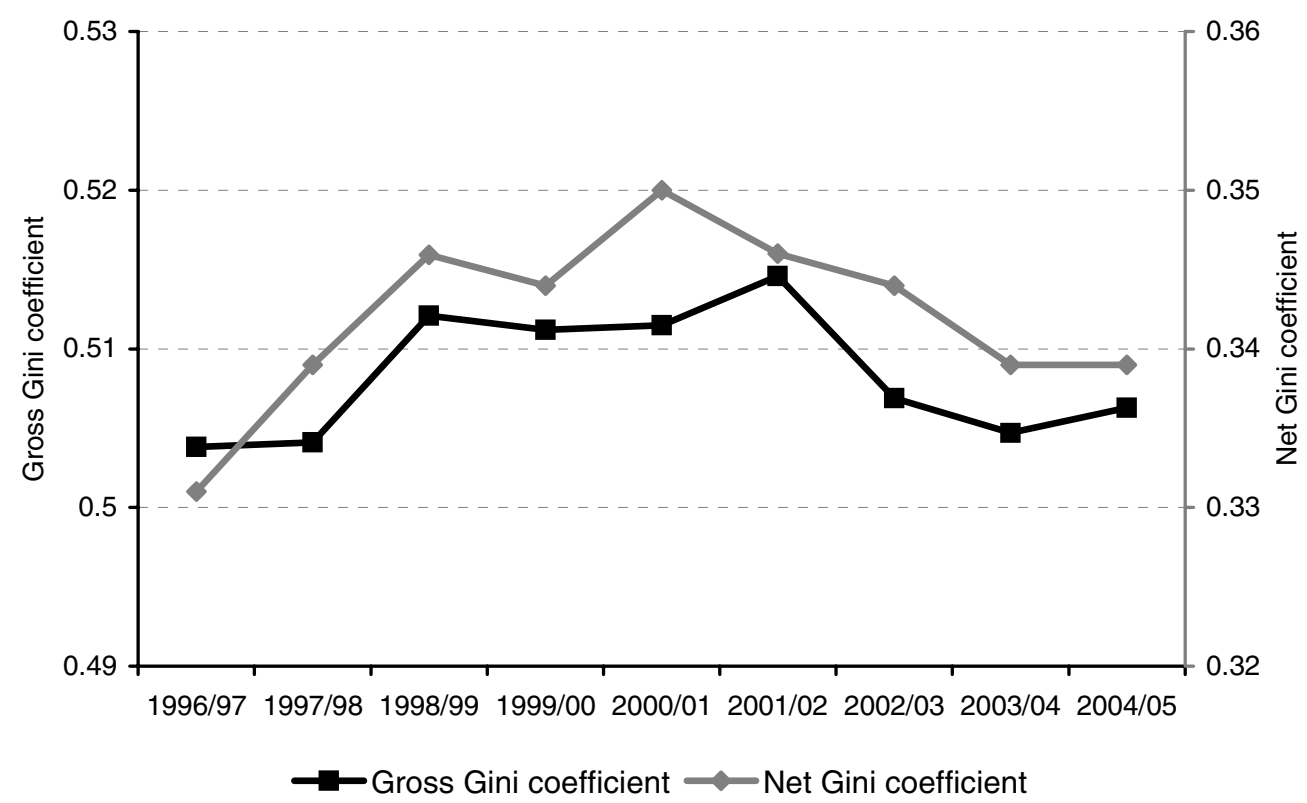

Note: The Gini coefficients have been calculated using incomes before housing costs have been deducted. Source: Authors' calculations using Family Resources Survey, various years.

This pattern in gross income inequality is perhaps surprising, given the amount of additional redistribution built into tax and benefit reforms over Labour's period in office. Despite this additional redistribution, what fall we have seen in net income inequality (on some measures) has also been seen in the distribution of gross incomes too. One possible explanation is that, had the 1996/97 tax and benefit system been left unreformed, it would have achieved less and less income redistribution as the population, economy and individual incomes have evolved over time. The reforms have therefore been required in order to keep the level of redistribution constant. For example, as the number of unemployed people has fallen, the shift towards in-work benefits has been required in order to maintain the same degree of redistribution, and therefore to prevent net income inequality from rising more sharply. However, further research is required to substantiate this hypothesis. 


\section{What future for income inequality?}

It is very difficult to predict how income inequality might evolve in the future. To the extent that it can be changed by government tax and benefit policy, some measures that might serve to reduce inequality very slightly have already been announced. These measures include uprating the pension credit and the child element of the child tax credit by earnings at least until 2007/08 and an increase in the proportion of childcare costs covered by the childcare element of the working tax credit from 70 per cent to 80 per cent in 2006/07. ${ }^{20}$ However, these changes are not as significant as those seen since 2000/01 that have served to reduce poverty and only slightly reduce inequality, suggesting that they may have little impact upon overall levels of inequality. Since the government has a tough target for reducing child poverty by 2010/11, there may be a need for policy commitments at least on a similar scale to those seen since 2000/01 (see Section 4.3). However, the scope for much more redistribution in the short to medium term would seem to be constrained by the future prospects for public expenditure: for example, the social security and tax credit expenditure increases pencilled in for the next few years only amount to 1.3 per cent per annum in real terms between 2004/05 and 2007/08. This is much smaller than the average annual real increase of 3.9 per cent since 2000/01.

Looking beyond 2007/08, the 2005 Pre-Budget Report set a provisional figure for overall public spending to grow by 1.8 per cent per annum in real terms between 2007/08 and 2010/11. However, once possible scenarios and commitments on the government's stated priority areas of health, education and overseas development assistance spending are taken into account, ${ }^{21}$ other spending (inclusive of social security and tax credits) can only grow by 0.8 per cent per year in real terms. It thus seems unlikely that social security and tax credit expenditure will be able to grow as much after 2007/08 as it did between 2000/01 and 2004/05, when the average annual real increase was 3.9 per cent. (See Chote, Emmerson and Frayne (2006) for more detailed analysis.)

Given the policy and spending commitments that have already been announced, there thus seems little room for further commitments that might serve to reduce income inequality substantially and help the government meet its 2010/11 child poverty target. Unless the Chancellor can dip into his pocket and find even more to finance his redistributive goals, or unless gross income inequality should fall sharply, even the small fall in income inequality seen since 2000/01 looks unlikely to be repeated.

Important considerations when looking beyond 2007/08 are the possibilities of a change in Prime Minister and of a change of government. If Gordon Brown becomes Prime Minister when Tony Blair chooses to step down, we would be unlikely to change our predictions, since it is Gordon Brown as Chancellor who has been setting much of the government's spending priorities since taking office. However, his close association with the government's child poverty and pensioner poverty goals might further increase the tension between the need to meet these goals and current spending plans going forward.

\footnotetext{
${ }^{20}$ HM Treasury, 2003 and 2004.

${ }^{21}$ These being: health spending growing by 4.4 per cent per year in real terms; overseas development assistance growing by 10.5 per cent per year in real terms so that it reaches 0.7 per cent of GDP by 2012/13; and education spending remaining constant as a proportion of GDP, so growing by 2.4 per cent per year in real terms.
} 
It is much more difficult to predict the likely effects upon poverty and inequality of any future Conservative government. Since becoming leader of the Conservative Party, David Cameron has been keen to change the party's rhetoric on poverty and redistribution. Oliver Letwin, who is leading the Conservatives' policy review process, told The Telegraph in a recent interview, 'Of course it should be an aim to narrow the gap between rich and poor' ${ }^{22}$ and told The World at One on 23 December 2005 that he wanted to find ways of 'empowering people at the bottom of the heap to have a larger share of an enlarging cake'. However, we will have to wait until the policy review process has produced specific proposals before we can draw any implications from the recent change in language. Similarly, whilst the Shadow Chancellor George Osborne has recently been stressing the importance of 'lower, simpler taxes', ${ }^{23}$ it also remains uncertain what this would mean in practice and how any changes might affect income inequality.

\subsection{Conclusion}

There has been a statistically insignificant rise in average income between 2003/04 and 2004/05 and little change in income inequality. Having increased over the late 1990s, income inequality now appears to have fallen back to the same level as when the Labour government came to power in 1997. However, considerable redistribution has been required just to reverse the modest rise in inequality during the Labour government's initial period of public spending restraint. The fact that the amount of public expenditure available for further redistribution is likely to grow by considerably less over the short to medium term than it has in recent years suggests that the reversal of the increase in inequality seen over the 1980s still seems an unlikely prospect any time soon.

\footnotetext{
22 'Letwin waves his wand over Tory thinking', www.telegraph.co.uk/news/main.jhtml?xml=/news/2005/12/23/nletwin123.xml.

${ }^{23}$ Speech to the Social Market Foundation on 7 September 2005.
} 


\section{Poverty in Britain}

In this chapter, we summarise the trends in the government's main income-based poverty indicators, which are all derived from HBAI data. These count the number of individuals below various fractions (50 per cent, 60 per cent and 70 per cent) of the income of the median individual - the individual in the middle of the income distribution. These indicators are known as 'relative' poverty indicators because whether someone is classed as being poor depends not just on their income but also on the income of the median individual. Opportunity for All, the government's annual audit of poverty, ${ }^{24}$ also includes measures where the poverty line is fixed in real terms at its 1996/97 level (called 'absolute' poverty indicators), measures that count individuals with persistent low incomes, and a wide range of other indicators that are not income-based. We do not consider any of these here.

Since the size of the population can change over time, it is often better to measure trends in poverty by the fraction of individuals that it affects, rather than by the number of individuals. Consequently, our tables and graphs present poverty rates, but we report how many people are poor in the text. We also report estimates of whether changes in poverty are statistically significant. $^{25}$

We begin in Section 3.1 by analysing recent changes in relative poverty for the population as a whole. We then focus on subgroups, examining poverty amongst the government's favoured target groups of children (in Section 3.2) and pensioners (in Section 3.3). In Section 3.4, we focus on poverty amongst a group that is not treated separately in the government's Opportunity for All report analysis - working-age adults without children. Section 3.5 concludes.

Table 3.1. Example poverty lines in 2004/05

\begin{tabular}{|c|c|c|c|c|c|c|}
\hline & \multicolumn{3}{|c|}{ After housing costs } & \multicolumn{3}{|c|}{ Before housing costs } \\
\hline & $\begin{array}{l}50 \% \\
\text { median }\end{array}$ & $\begin{array}{c}60 \% \\
\text { median }\end{array}$ & $\begin{array}{c}70 \% \\
\text { median }\end{array}$ & $\begin{array}{l}50 \% \\
\text { median }\end{array}$ & $\begin{array}{c}60 \% \\
\text { median }\end{array}$ & $\begin{array}{l}70 \% \\
\text { median }\end{array}$ \\
\hline Childless couple & $£ 152$ & $£ 183$ & $£ 213$ & $£ 175$ & $£ 210$ & $£ 245$ \\
\hline Single individual & $£ 84$ & $£ 100$ & $£ 117$ & $£ 107$ & $£ 128$ & $£ 149$ \\
\hline $\begin{array}{l}\text { Couple with one child } \\
\text { aged } 8\end{array}$ & $£ 187$ & $£ 225$ & $£ 262$ & $£ 215$ & $£ 258$ & $£ 301$ \\
\hline $\begin{array}{l}\text { Couple with two children } \\
\text { aged } 1 \text { and } 3\end{array}$ & $£ 190$ & $£ 228$ & $£ 266$ & $£ 222$ & $£ 266$ & $£ 311$ \\
\hline $\begin{array}{l}\text { Lone parent with one child } \\
\text { aged } 8\end{array}$ & $£ 119$ & $£ 142$ & $£ 166$ & $£ 147$ & $£ 176$ & $£ 205$ \\
\hline $\begin{array}{l}\text { Lone parent with two children } \\
\text { aged } 1 \text { and } 3\end{array}$ & $£ 122$ & $£ 146$ & $£ 170$ & $£ 154$ & $£ 184$ & $£ 215$ \\
\hline
\end{tabular}

Source: Authors' calculations based on Family Resources Survey, 2004/05.

\footnotetext{
${ }^{24}$ Most recently, Department for Work and Pensions (2005a).

${ }^{25}$ These were calculated by bootstrapping the changes. This involves recalculating statistics for each of a series of random samples drawn from the original sample, as a way of approximating the distribution of statistics that would be calculated from different possible samples out of the underlying population. See Davison and Hinkley (1997). See also Box 3.1 below.
} 
Table 3.1 shows the level of the poverty line in pounds in 2004/05 for a number of different family types when the poverty line is set at 50,60 and 70 per cent of median income. These poverty lines are used throughout this chapter.

\subsection{The whole population}

Figures 3.1 and 3.2 show the trends in relative poverty in Britain since 1979. They illustrate the well-known trend that poverty rates increased dramatically during the 1980s, more slowly in the early 1990s, and then stabilised or fell from the mid-1990s. The two graphs also show the historical tendency for poverty rates measured after housing costs (AHC) to be higher than those measured before housing costs (BHC); this is because the distribution of income is more heavily skewed when measured AHC.

Table 3.2 contains more detailed information on poverty rates since 1996/97. Poverty has been on a downward trend over both parliamentary terms of the current government. Compared with 1996/97, it is now between 3 and 5 percentage points lower measured AHC, and up to 2.3 percentage points lower measured BHC. With the poverty line at 60 per cent of median income, there are now 11.4 million individuals in poverty measured AHC and 9.2 million measured BHC, down from 13.8 million and 10.2 million respectively in 1996/97. For all measures, poverty in 2004/05 is statistically significantly lower than it was in 1996/97 (and than in 1998/99, the baseline against which the current government has chosen to measure progress on child poverty). With the poverty line set at 60 per cent of median income, poverty measured AHC has fallen from just under a quarter of the population in 1996/97 to just under a fifth in 2004/05.

Figure 3.1. Relative poverty in Britain: percentage of individuals in households with income below various fractions of median AHC income

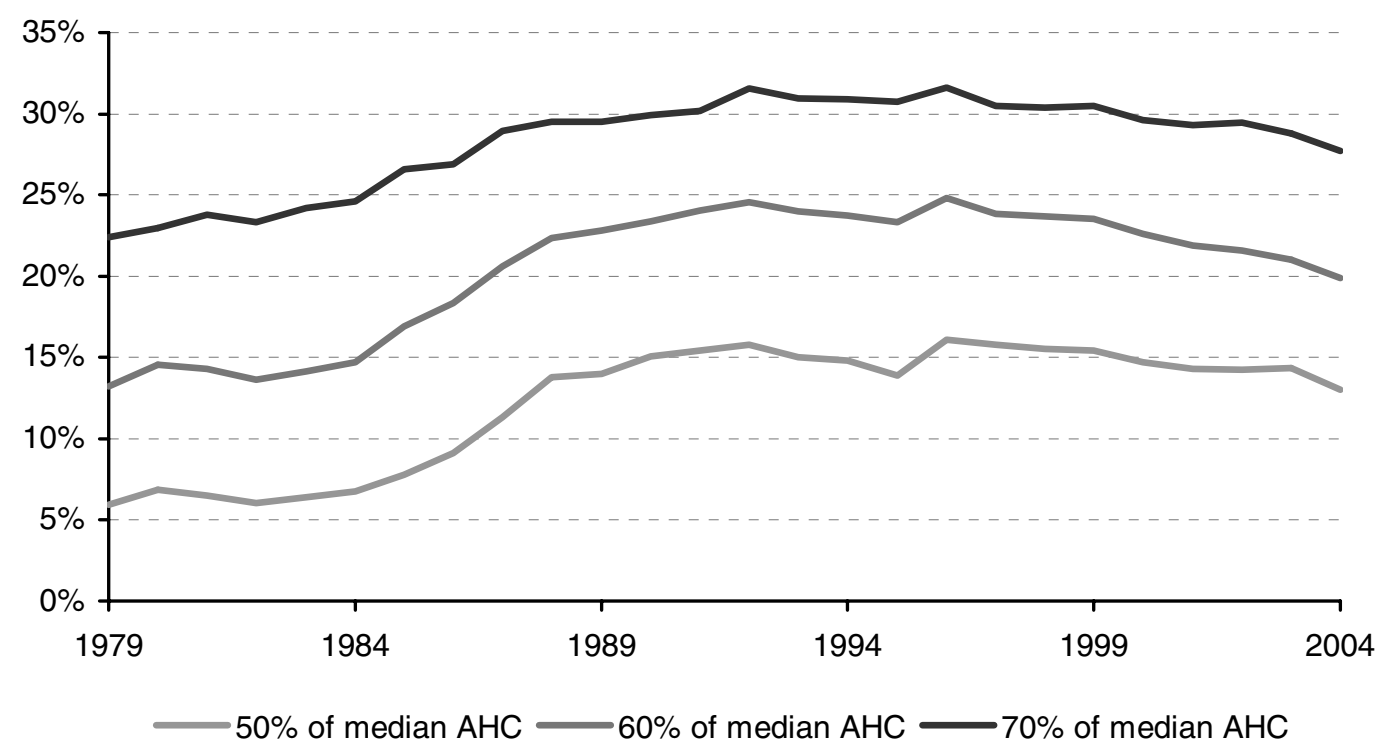

Note: Data from 1993 onwards are for financial years, i.e. 1993/94 etc.

Source: Authors' calculations based on Family Expenditure Survey and Family Resources Survey, various years. 
Figure 3.2. Relative poverty in Britain: percentage of individuals in households with income below various fractions of median $\mathrm{BHC}$ income

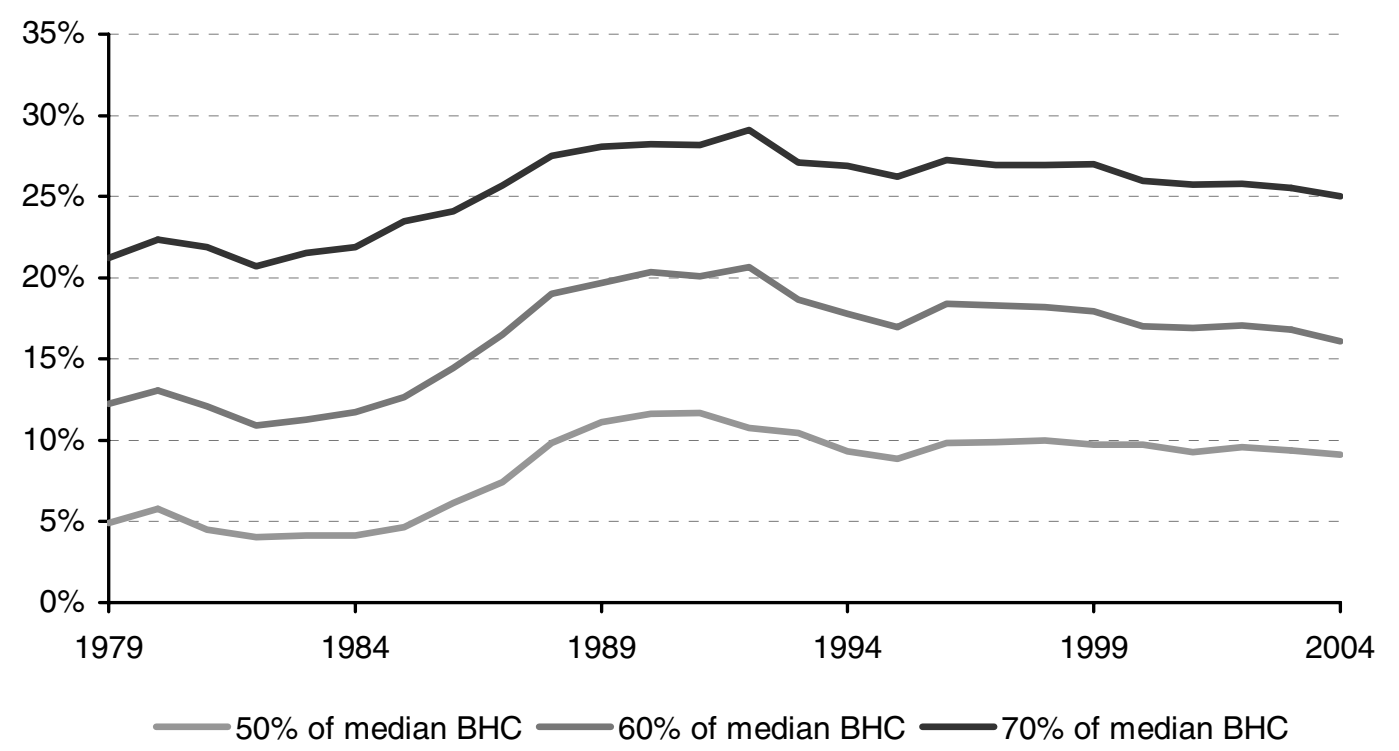

Note: Data from 1993 onwards are for financial years, i.e. 1993/94 etc.

Source: Authors' calculations based on Family Expenditure Survey and Family Resources Survey, various years.

Table 3.2. Relative poverty in Britain: percentage of individuals in households with income below various fractions of median income

\begin{tabular}{|c|c|c|c|c|c|c|c|}
\hline & \multicolumn{6}{|c|}{ Percentage of the population } & \multirow{3}{*}{$\begin{array}{c}\text { Population } \\
\text { (million) }\end{array}$} \\
\hline & \multicolumn{3}{|c|}{ After housing costs } & \multicolumn{3}{|c|}{ Before housing costs } & \\
\hline & $\begin{array}{c}50 \% \\
\text { median }\end{array}$ & $\begin{array}{c}60 \% \\
\text { median }\end{array}$ & $\begin{array}{c}70 \% \\
\text { median }\end{array}$ & $\begin{array}{c}50 \% \\
\text { median }\end{array}$ & $\begin{array}{c}60 \% \\
\text { median }\end{array}$ & $\begin{array}{c}70 \% \\
\text { median }\end{array}$ & \\
\hline 1996/97 & 16.1 & 24.8 & 31.6 & 9.9 & 18.4 & 27.3 & 55.6 \\
\hline $1997 / 98$ & 15.8 & 23.8 & 30.5 & 9.9 & 18.3 & 26.9 & 55.7 \\
\hline 1998/99 & 15.6 & 23.7 & 30.4 & 10.0 & 18.2 & 27.0 & 55.9 \\
\hline 1999/00 & 15.4 & 23.5 & 30.5 & 9.7 & 17.9 & 27.0 & 56.1 \\
\hline 2000/01 & 14.7 & 22.6 & 29.6 & 9.7 & 17.0 & 26.0 & 56.2 \\
\hline 2001/02 & 14.3 & 21.9 & 29.3 & 9.3 & 16.9 & 25.7 & 56.4 \\
\hline 2002/03 & 14.2 & 21.6 & 29.5 & 9.6 & 17.0 & 25.8 & 56.6 \\
\hline 2003/04 & 14.3 & 21.0 & 28.8 & 9.4 & 16.8 & 25.5 & 56.8 \\
\hline 2004/05 & 13.0 & 19.9 & 27.7 & 9.1 & 16.1 & 25.0 & 57.1 \\
\hline \multicolumn{8}{|l|}{ Change: } \\
\hline Since 1996/97 & -3.1 & -4.9 & -3.9 & -0.7 & -2.3 & -2.2 & \\
\hline Since 1998/99 & -2.6 & -3.7 & -2.7 & -0.9 & -2.2 & -1.9 & \\
\hline
\end{tabular}


Comparing 2004/05 with 2003/04, poverty is lower for all six measures in Table 3.2, and all but two of these falls were statistically significant (the two exceptions being 50 and 70 per cent of median BHC). ${ }^{26}$

Figure 3.3 presents the cumulative distribution of incomes relative to the median measured BHC and AHC in 1996/97 and 2004/05. (Only the sections up to and including the median income are shown. By definition, 50 per cent of the population have incomes below the median.) This allows us to see whether our assessment of the fall in relative poverty is sensitive to the specific choice of poverty line. It suggests that whilst there have been reductions in the proportion of the population below between 40 and 100 per cent of the AHC median since 1996/97, the biggest fall is at around the threshold of 60 per cent of the AHC median; at the same time, there has been a slight rise in the proportion of individuals whose income falls below fractions lower than 40 per cent of the median. A similar story can be seen with income measured $\mathrm{BHC}$, with the proportion in poverty falling at all thresholds above about 45 per cent of the median.

Figure 3.3. Cumulative distribution of incomes relative to the median
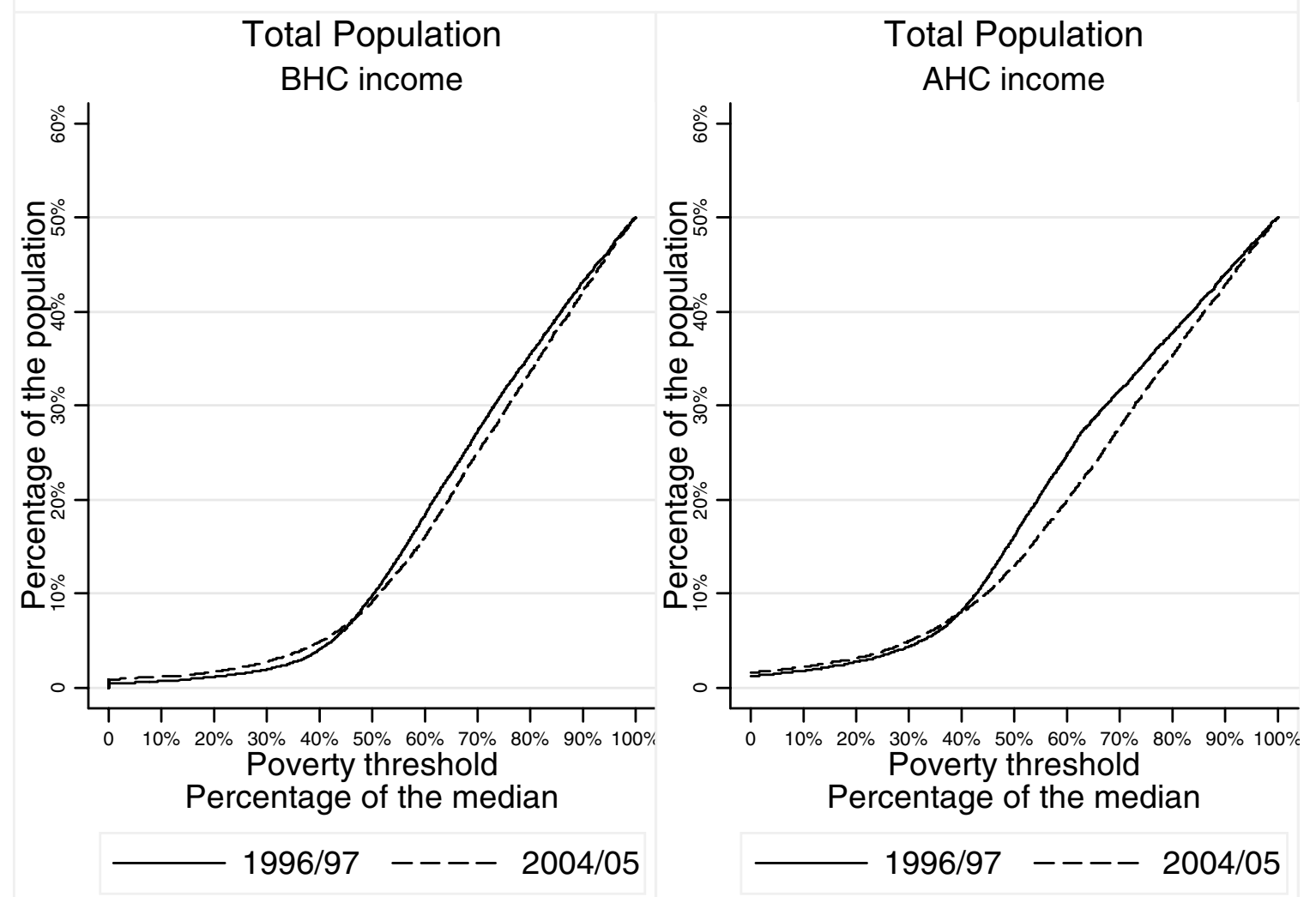

Source: Authors' calculations using Family Resources Survey, 1996/97 and 2004/05.

${ }^{26}$ Historically, it is rare for year-on-year changes to be statistically significant. 


\subsection{Child poverty and the 2004/05 target}

Child poverty has been on a downward trend since 1998/99, following a large rise in child poverty during the 1980 s and early 1990 s. ${ }^{27}$ Child poverty is lower in 2004/05 than in 2003/04 on five of the six measures in Table 3.3 (the exception being 70 per cent of median AHC), but only one of the six changes is statistically significant (50 per cent of median AHC). However, the changes in child poverty since 1996/97 and 1998/99 are all statistically significant.

To help us see how sensitive these conclusions about falling child poverty are to the exact choice of poverty line, Figure 3.4 shows the cumulative distribution of incomes relative to the median for children in 1996/97 and 2004/05. (Again, only the section below the median is shown. Notice that around 60 per cent of children live in households with income below the population median.) Looking at AHC incomes first, the graph shows that the proportions of children with household income below thresholds between about 40 per cent and 90 per cent of the median income have fallen. However, it also shows little change, if not a slight rise, in the proportions with income below thresholds less than 40 per cent of the median.

The Department for Work and Pensions and HM Treasury have a joint Public Service Agreement (PSA) target for the number of children in poverty in 2004/05 to be a quarter lower than its 1998/99 level, using a poverty line of 60 per cent of median income. Given the target is defined in terms of the number of children rather than the proportion of children, Table 3.4 gives poverty headcounts for all years of the child poverty target.

Table 3.3. Relative child poverty: percentage of children living in households with income below various fractions of median income

\begin{tabular}{|c|c|c|c|c|c|c|c|}
\hline & \multicolumn{6}{|c|}{ Percentage of the child population } & \multirow{3}{*}{$\begin{array}{c}\text { Child } \\
\text { population } \\
\text { (million) }\end{array}$} \\
\hline & \multicolumn{3}{|c|}{ After housing costs } & \multicolumn{3}{|c|}{ Before housing costs } & \\
\hline & $\begin{array}{l}50 \% \\
\text { median }\end{array}$ & $\begin{array}{c}60 \% \\
\text { median }\end{array}$ & $\begin{array}{c}70 \% \\
\text { median }\end{array}$ & $\begin{array}{c}50 \% \\
\text { median }\end{array}$ & $\begin{array}{c}60 \% \\
\text { median }\end{array}$ & $\begin{array}{c}70 \% \\
\text { median }\end{array}$ & \\
\hline 1996/97 & 22.9 & 33.3 & 41.2 & 12.5 & 24.9 & 35.2 & 12.7 \\
\hline 1997/98 & 22.9 & 32.4 & 40.1 & 12.6 & 24.7 & 35.2 & 12.7 \\
\hline 1998/99 & 22.7 & 32.5 & 40.4 & 12.6 & 24.5 & 35.1 & 12.7 \\
\hline 1999/00 & 21.8 & 31.9 & 40.2 & 11.7 & 23.4 & 35.1 & 12.7 \\
\hline 2000/01 & 19.7 & 30.3 & 38.6 & 11.1 & 21.0 & 32.8 & 12.7 \\
\hline 2001/02 & 19.3 & 29.6 & 38.3 & 10.4 & 20.7 & 33.1 & 12.6 \\
\hline 2002/03 & 19.0 & 28.3 & 37.6 & 10.6 & 20.8 & 32.4 & 12.6 \\
\hline 2003/04 & 19.0 & 27.8 & 36.4 & 10.5 & 20.5 & 31.8 & 12.5 \\
\hline 2004/05 & 17.0 & 27.2 & 36.5 & 10.5 & 19.5 & 31.5 & 12.6 \\
\hline \multicolumn{8}{|l|}{ Change: } \\
\hline Since 1996/97 & -5.9 & -6.1 & -4.7 & -2.0 & -5.4 & -3.6 & \\
\hline Since $1998 / 99$ & -5.6 & -5.3 & -3.9 & -2.1 & -5.0 & -3.6 & \\
\hline
\end{tabular}

Notes: Reported changes may not equal the differences between the corresponding percentages due to rounding. All changes are significantly different from zero at the 5 per cent level.

Sources: Authors' calculations based on Family Resources Survey, various years. Population totals are from the HBAI data-set.

${ }^{27}$ See Brewer, Clark and Goodman (2002 or 2003). 
Figure 3.4. Cumulative distribution of incomes relative to the median: children only

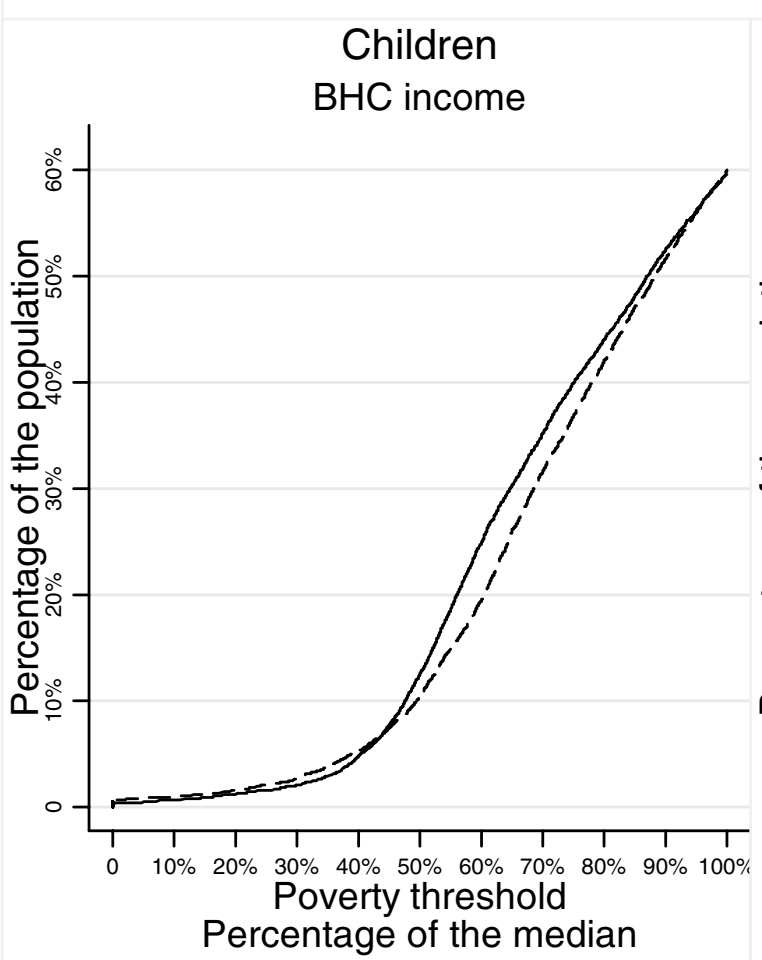

$1996 / 97$

$2004 / 05$

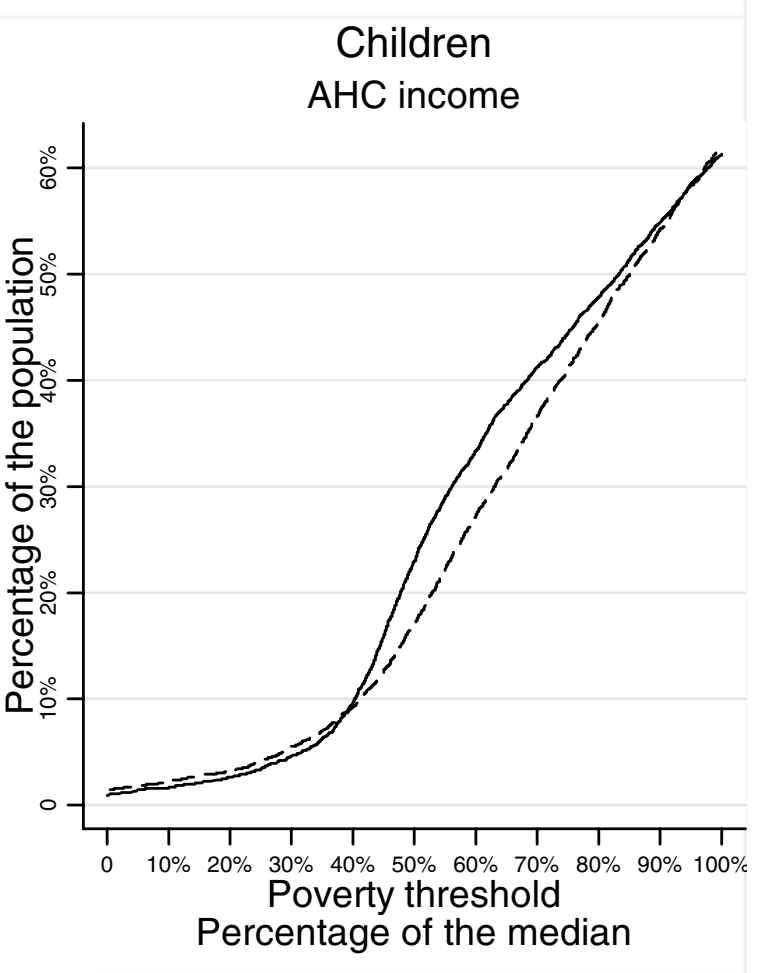

$1996 / 97$

$2004 / 05$

Source: Authors' calculations using Family Resources Survey, 1996/97 and 2004/05.

Table 3.4. Relative child poverty: number of children living in households with income below various fractions of median income

\begin{tabular}{l|ccc|ccc|c}
\hline & \multicolumn{6}{|c|}{ Number of children (million) } & \multicolumn{2}{c}{ Child } \\
& \multicolumn{2}{|c|}{ After housing costs } & \multicolumn{2}{c}{ Before housing costs } & population \\
& $\mathbf{5 0 \%}$ & $\mathbf{6 0 \%}$ & $\mathbf{7 0 \%}$ & $\mathbf{5 0 \%}$ & $\mathbf{6 0 \%}$ & $\mathbf{7 0 \%}$ & (million) \\
& median & median & median & median & median & median & \\
\hline $1998 / 99$ & 2.9 & 4.1 & 5.1 & 1.6 & 3.1 & 4.5 & 12.7 \\
$1999 / 00$ & 2.8 & 4.1 & 5.1 & 1.5 & 3.0 & 4.5 & 12.7 \\
$2000 / 01$ & 2.5 & 3.8 & 4.9 & 1.4 & 2.7 & 4.2 & 12.7 \\
$2001 / 02$ & 2.4 & 3.7 & 4.8 & 1.3 & 2.6 & 4.2 & 12.6 \\
$2002 / 03$ & 2.4 & 3.6 & 4.7 & 1.3 & 2.6 & 4.1 & 12.6 \\
$2003 / 04$ & 2.4 & 3.5 & 4.6 & 1.3 & 2.6 & 4.0 & 12.5 \\
$2004 / 05$ & 2.1 & 3.4 & 4.6 & 1.3 & 2.4 & 4.0 & 12.6 \\
Change: & & & & & & & \\
Since 1998/99 & -0.7 & -0.7 & -0.6 & -0.3 & -0.7 & -0.5 & \\
\hline
\end{tabular}

Notes: Reported changes may not equal the differences between the corresponding numbers due to rounding. All changes are significantly different from zero at the 5 per cent level.

Sources: Authors' calculations based on Family Resources Survey, various years. Population totals are from the HBAI data-set. 


\section{Box 3.1. Statistical significance and the child poverty target}

When answering the question, 'Can we be statistically certain that the child poverty target has been missed?', there are two different approaches that can be taken.

First, one can define a level of child poverty in 2004/05 that would be consistent with a fall in child poverty of 25 per cent. If one follows the usual practice in HBAI of reporting numbers in poverty rounded to the nearest 100,000 , then, when measured AHC, child poverty must have fallen to at least 3.0 million for there to have been at least a 25 per cent fall in child poverty since 1998/99. However, we calculate the 95 per cent confidence interval for child poverty measured AHC in 2004/05 to be 3.26 million to 3.57 million. Therefore, we can be 95 per cent sure that the child poverty target was missed under the AHC definition of the target. The conclusion is the same if one assesses the decline in poverty based on the unrounded estimates of the number of children in poverty in 1998/99 and 2004/05. Measured BHC, the picture is not so clear-cut, and depends upon exactly how the target is expressed. Using rounded figures to express the target, child poverty must be statistically higher than 2.3 million for the target to have been missed. We calculate the confidence interval for this statistic to be 2.31 million to 2.59 million. Therefore, on this interpretation of the target, we can (just) be 95 per cent sure that the child poverty target was missed under the BHC definition of the target. On the basis of unrounded figures, however, the target for 2004/05 would be 2,327,900 children, which lies just above the lower bound of the confidence interval, suggesting that on this basis we cannot be 95 per cent confident that the BHC target has been missed (though we can be 90 per cent confident that this target was missed).

Alternatively, since the target is to reduce child poverty by 25 per cent, one can ask if the proportionate fall in child poverty between $1998 / 99$ and 2004/05 is statistically different from 25 per cent. We calculate the 95 per cent confidence intervals to be 15.6 to 26.0 per cent measured BHC and 12.1 to 22.4 per cent measured AHC. We can thus be at least 95 per cent confident that the target was missed when considering poverty measured AHC, but not for poverty measured $\mathrm{BHC}$ (though we can be 90 per cent confident that this target was missed when measured $\mathrm{BHC}$ ).

Whichever approach is taken, there are also different methods for estimating these confidence intervals. Department for Work and Pensions (2005b) estimates the confidence intervals using an approximation to the true analytical expression. This approximation reflects that not only are the incomes of low-income families with children not known for certain, but neither is median income nor the poverty line.

As an alternative, we have calculated standard errors and confidence intervals using bootstrap techniques. These involve approximating the actual distribution of a statistic by repeatedly drawing (with replacement) a random sample from the original data and using it to recalculate the statistic. We are of the opinion that the bootstrap represents the most accurate estimate of the standard error due to the sheer number of replications we perform, and given that the analytical estimate is an approximation.

Based on the bootstrap technique, our estimates of the standard error of the level of child poverty in 2003/04 were slightly higher than those in Department for Work and Pensions (2005b), which estimated it at 60,000: with 1,000 replications, we estimate the standard error to be 78,000 in 2003/04 (Brewer et al., 2005). If we assume that the DWP estimate of the standard error for 2004/05 is similar to its previous estimates, then the likelihood of having met the child poverty target in 2004/05 is reduced compared with our estimated standard errors of 76,000 BHC and 85,000 AHC in 2004/05. 
When poverty is measured AHC, there were 4.1 million children in poverty in 1998/99 using the 60 per cent of median income definition, so the target required that there be 3.0 million or fewer children in poverty in 2004/05 - child poverty had to fall by 1.1 million. Measured BHC, 3.1 million children were in poverty in 1998/99, so the target required that 2.3 million children or fewer be in poverty in 2004/05 - a fall of 0.8 million children.

The figures in the bottom line of Table 3.4 show that the government has fallen about 100,000 children short of meeting the target BHC and about 400,000 children short AHC. ${ }^{28}$ Based on unrounded figures, the number of children in poverty has fallen by 21.3 per cent BHC and 17.2 per cent AHC since 1998/99, both short of the 25 per cent target.

Like every statistic calculated from the HBAI data, the figures given above for child poverty are estimates based on a sample of households in Britain. Because of this, there will be a confidence interval around each estimate (see Box 3.1 on how these are calculated). The government has simply defined the child poverty target as cutting child poverty by 25 per cent, with no reference to statistical significance. We feel it is still highly informative to see whether child poverty in 2004/05 is statistically different from the target.

When measured AHC, we can give an unambiguous answer to this question - namely, that even when taking into account possible sampling error in measuring the true rate of child poverty, or the true change since 1998/99, we can be 95 per cent confident that the target was missed. However, we cannot give a completely unambiguous answer to the question when measuring income BHC. Box 3.1 provides further details.

Figures 3.5 and 3.6 show the actual paths of the number of children in poverty measured AHC and BHC between 1996/97 and 2004/05, together with a straight line showing the path

Figure 3.5. Relative child poverty measured AHC: number of children living in households with income below 60 per cent of median income

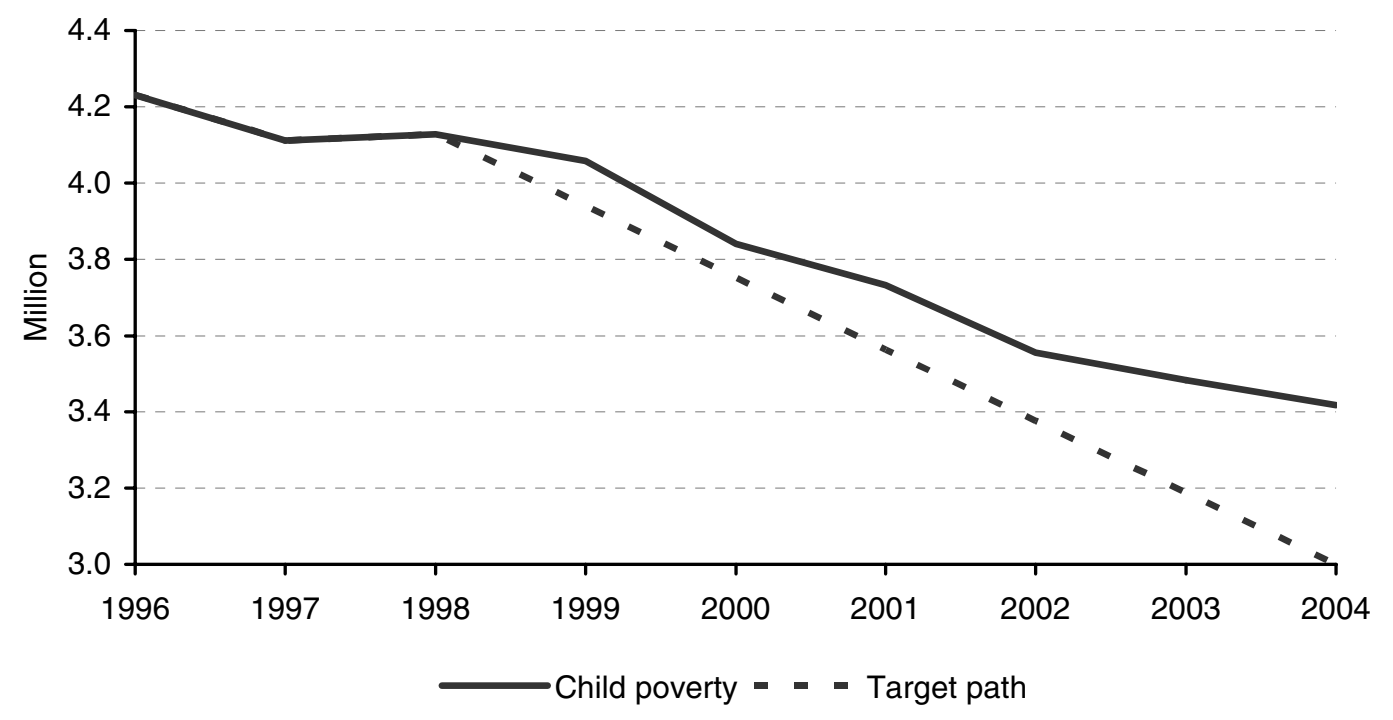

Note: Years are financial years (e.g. 1996 refers to financial year 1996/97).

\footnotetext{
${ }^{28}$ Please note that the numbers here refer to the difference between the respective target value rounded to the nearest 100,000 and the rounded child poverty level in 2004/05.
} 
Figure 3.6. Relative child poverty measured BHC: number of children living in households with income below 60 per cent of median income

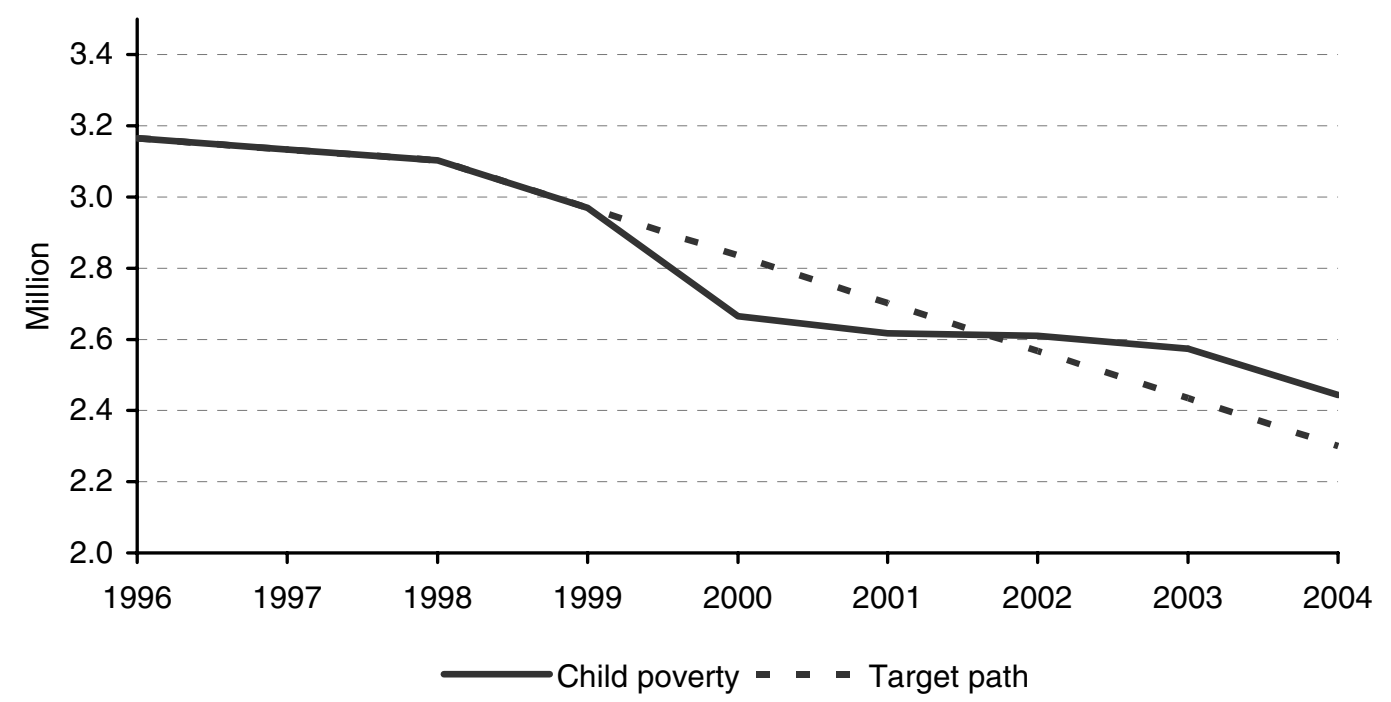

Note: Years are financial years (e.g. 1996 refers to financial year 1996/97).

that child poverty would have followed had the government met this year's target through equal reductions each year since 1998/99. Child poverty measured BHC fell quite substantially in 2000/01, putting the government ahead of schedule. However, since then, it has fallen only very slightly, leading to this year's level falling short of the target by approximately 100,000. Measured AHC, we see that the actual path was not that far from the required path up until 2002/03; however, in the two years since, the falls in child poverty have slowed considerably, leading to the target being missed by about 400,000 measured AHC.

The bowing-out of the actual path relative to the target path implies that the 2010 target to cut child poverty by 50 per cent and the 2020 target to 'eradicate' child poverty, ${ }^{29}$ both measured BHC, are going to be even harder to hit. See Chapter 4 for more details.

It is undoubtedly embarrassing for the government to have missed such a high-profile target. However, we should remember two important things:

- Although the 2004/05 targets have been missed, child poverty has fallen substantially since Labour came to power.

- Until last year, many external commentators (ourselves included) thought that the government had probably done just enough to meet its targets.

In Chapter 4, we discuss how the fall in child poverty has been achieved, and tackle the difficult issue of why those predictions were wrong.

\footnotetext{
${ }^{29}$ Defined by the DWP as being 'amongst the best in Europe'; see Department for Work and Pensions (2003).
} 


\subsection{Pensioner poverty}

Table 3.5 sets out poverty rates amongst pensioners since 1996/97 and shows that pensioner poverty continues to decline rapidly. ${ }^{30}$ Pensioner poverty is substantially lower in 2004/05 than in 2003/04 under all six measures, and all but one of these changes were statistically significant (the exception being 50 per cent of median BHC). Using the 60 per cent of median AHC income poverty line, the fall between 2003/04 and 2004/05 was over 2.5 percentage points, meaning that the number of pensioners in poverty fell by nearly 13 per cent in a single year. Measured BHC, poverty fell by between 0.5 and 1.7 percentage points between 2003/04 and 2004/05, and it is now lower than at any point since the mid-1980s.

Looking over the period of the child poverty target (1998/99 to 2004/05), the drop in pensioner poverty on the 60 per cent AHC measure was 10.4 percentage points, constituting a decline of more than a third. On the 60 per cent BHC measure, the drop was considerably smaller, at 4.2 percentage points, representing an 18 per cent decline. Since 1996/97, the decline on the AHC measure was 11.0 percentage points (or a drop of 1 million, from 2.8 million pensioners in poverty to 1.8 million pensioners in poverty); on the BHC measure, the decline was 2.6 percentage points (or a drop of around 200,000 pensioners, from 2.2 million to 2.0 million).

Table 3.5. Relative pensioner poverty: percentage of pensioners living in households with income below various fractions of median income

\begin{tabular}{l|ccc|ccc|c}
\hline & \multicolumn{6}{|c|}{ Percentage of the pensioner population } & Pensioner \\
& \multicolumn{2}{|c|}{ After housing costs } & \multicolumn{2}{c}{ Before housing costs } & Population \\
& $\mathbf{5 0 \%}$ & $\mathbf{6 0} \%$ & $\mathbf{7 0} \%$ & $\mathbf{5 0 \%}$ & $\mathbf{6 0 \%}$ & $\mathbf{7 0 \%}$ & (million) \\
& median & median & median & median & median & median & \\
\hline $1996 / 97$ & 12.1 & 27.9 & 39.2 & 11.3 & 22.1 & 36.1 & 9.9 \\
$1997 / 98$ & 12.5 & 27.4 & 38.4 & 11.9 & 22.7 & 36.6 & 10.0 \\
$1998 / 99$ & 12.6 & 27.3 & 38.1 & 12.5 & 23.7 & 37.5 & 10.0 \\
$1999 / 00$ & 12.1 & 26.1 & 37.2 & 11.7 & 22.6 & 36.0 & 10.0 \\
$2000 / 01$ & 11.3 & 24.4 & 35.8 & 11.2 & 21.9 & 35.1 & 10.1 \\
$2001 / 02$ & 11.1 & 23.2 & 36.6 & 11.4 & 22.8 & 34.7 & 10.1 \\
$2002 / 03$ & 10.5 & 22.1 & 36.7 & 11.0 & 22.2 & 34.6 & 10.2 \\
$2003 / 04$ & 9.8 & 19.7 & 34.2 & 9.9 & 21.0 & 33.6 & 10.3 \\
$2004 / 05$ & 8.2 & 17.0 & 29.6 & 9.4 & 19.5 & 31.9 & 10.4 \\
& & & & & & & \\
Change: & & & & & & & \\
Since 1996/97 & -3.9 & -11.0 & -9.6 & -1.9 & -2.6 & -4.2 & \\
Since 1998/99 & -4.4 & -10.4 & -8.5 & -3.1 & -4.2 & -5.7 & \\
\hline
\end{tabular}

Notes: Reported changes may not equal the differences between the corresponding percentages due to rounding. All changes are significantly different from zero at the 5 per cent level.

Sources: Authors' calculations based on Family Resources Survey, various years. Population totals are from the HBAI data-set.

\footnotetext{
${ }^{30}$ The table shows the poverty rate amongst individuals above the current pension age -65 for men and 60 for women - regardless of who else lives in their household.
} 
Figure 3.7. Pensioner and non-pensioner poverty

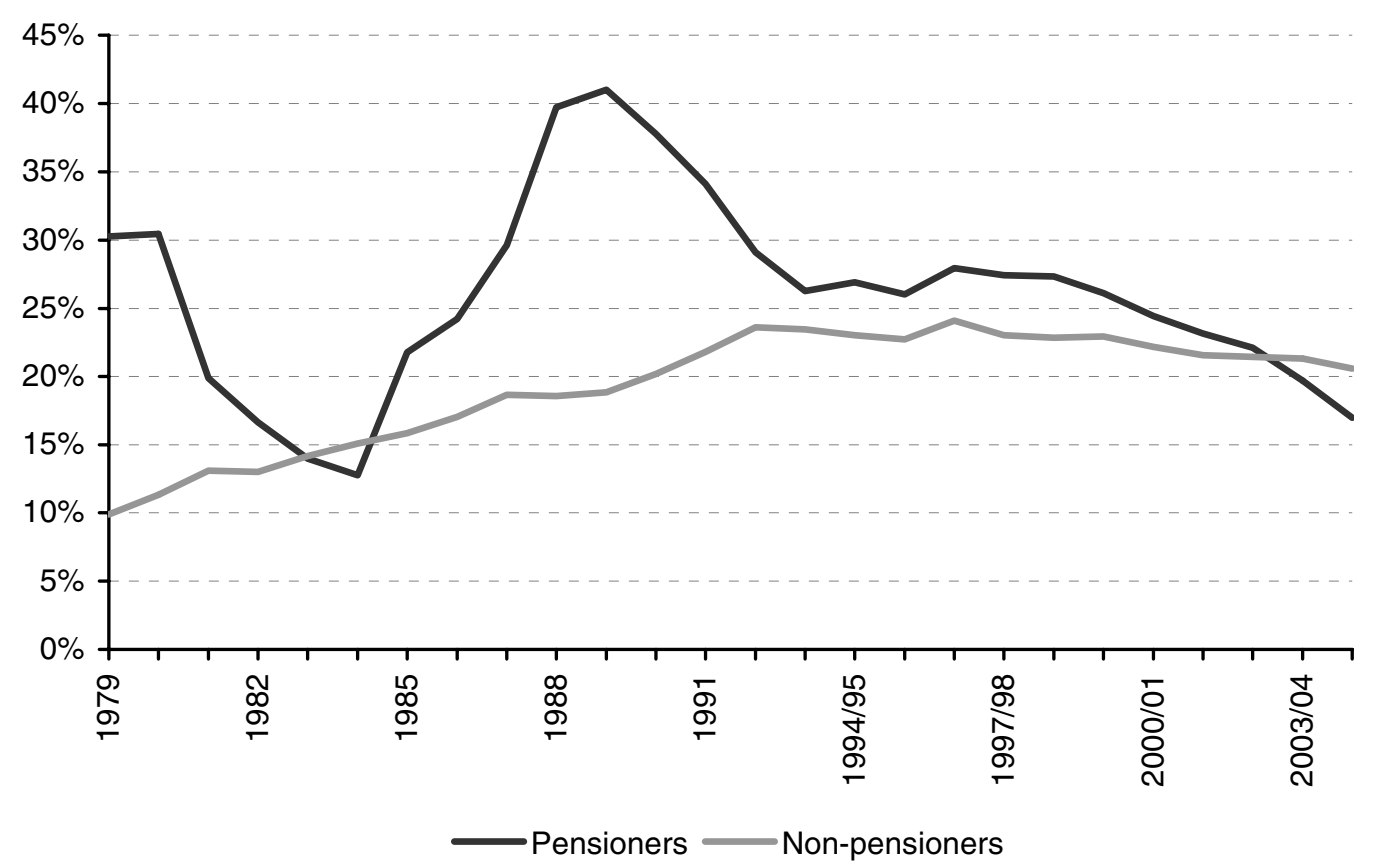

Note: Poverty is measured using the 60 per cent of median AHC income definition.

Source: Authors' calculations based on Family Resources Survey and Family Expenditure Survey, various years.

Figure 3.8. Cumulative distribution of incomes relative to the median: pensioners only

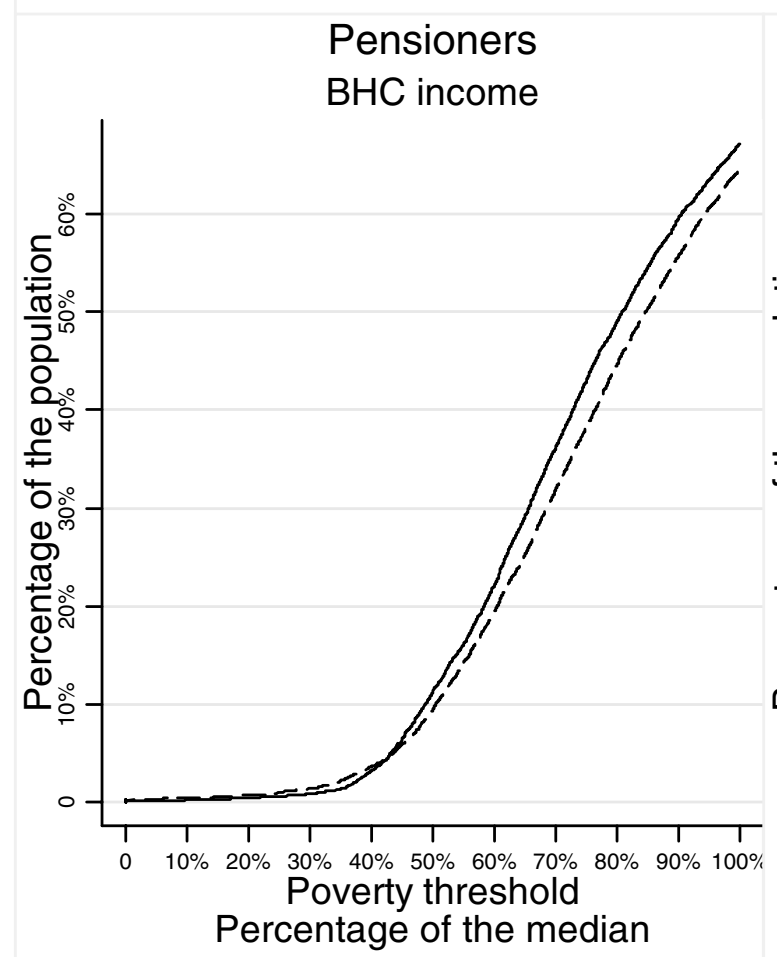

$1996 / 97$
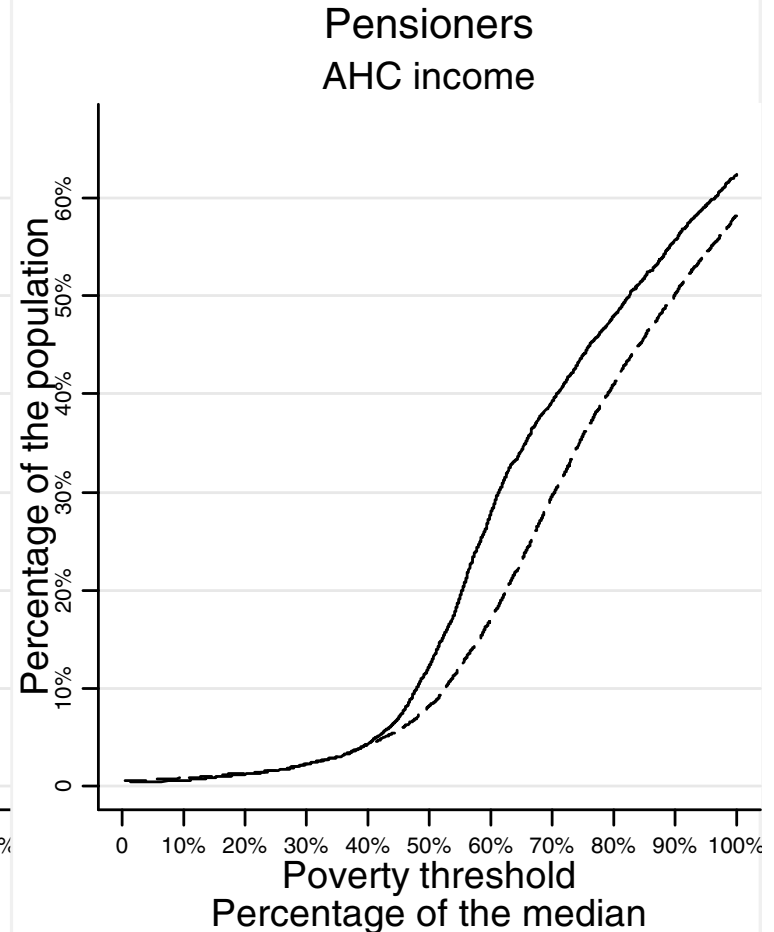

$1996 / 97----2004 / 05$

Source: Authors' calculations using Family Resources Survey, 1996/97 and 2004/05. 
As a result of these trends, this is now the second year in a row that, using the 60 per cent AHC measure, a pensioner chosen at random is less likely to be in poverty than an individual selected at random from the rest of the population. This is shown in Figure 3.7, which gives poverty rates for pensioners and non-pensioners. However, it remains the case that pensioners are more likely to be found below the 60 per cent median threshold BHC than the nonpensioner population.

Figure 3.8 highlights that the trend in falling pensioner poverty is not particularly sensitive to the exact choice of poverty line, for all thresholds above 40 per cent of the median. The graph shows a similar story to that shown for families with children and for the population as a whole: a falling proportion of pensioners in poverty using thresholds between 40 and 100 per cent of the median, but very little change in the proportions of pensioners on incomes below thresholds less than 40 per cent of the median. As we might expect, this pattern is stronger AHC than it is BHC.

As is evident from Table 3.5 and Figure 3.8, poverty measured AHC has fallen by much more than poverty measured $\mathrm{BHC}$. This is primarily because average pensioner housing costs have fallen, by 15 per cent in real terms between 1996/97 and 2004/05. By contrast, non-pensioner housing costs have risen in real terms by 19 per cent over the same time frame. As a result, housing costs account for a much lower proportion of pensioners' BHC income in 2004/05 than in 1996/97, whilst they have remained roughly constant as a proportion of nonpensioners' BHC income. These differential trends can be accounted for by the rising proportion of pensioners (generally amongst new retirees) who own their home outright, resulting in very low housing costs: this proportion has risen from 59 per cent in 1996/97 to 68 per cent in 2004/05.

\section{Why has pensioner poverty fallen so rapidly?}

The pensioner population is constantly evolving, as younger cohorts reach retirement age and older cohorts die out. It is important to understand whether the rapidly falling pensioner poverty in recent years (on the AHC measure) is due to changes in the composition of the pensioner population or whether it is due to a falling 'risk' of poverty amongst those already retired.

We can go some way towards answering this question by decomposing the change in poverty since 1996/97 into a 'compositional effect' and an 'incidence effect', following the methodology used in Sutherland, Sefton and Piachaud (2003), which is explained and set out more fully in Chapter 4, where we undertake a number of decompositions of child poverty, and in Appendix D. Here, we break down the pensioner population into five-year birth cohorts (based on the date of birth of the oldest in the family). We focus on explaining the reduction in poverty on the 60 per cent median AHC measure, where the reductions in poverty since 1996/97 have been particularly pronounced.

Table 3.6 first shows how much the composition of the pensioner population has changed since 1996/97. Whilst those born in or before 1915 accounted for almost 1 in 5 of the pensioner population in 1996/97, by 2004/05 they accounted for less than 1 in 20; similarly, while those born after 1935 made up just 1 in 100 pensioners in 1996/97, almost 30 per cent of all pensioners in 2004/05 were born after 1935. 
Table 3.6. Decomposition of change in relative pensioner poverty (AHC), 1996/97 - 2004/05

\begin{tabular}{|c|c|c|c|c|c|c|c|}
\hline & \multicolumn{2}{|c|}{$\begin{array}{c}\text { Percentage of } \\
\text { pensioner population }\end{array}$} & \multicolumn{2}{|c|}{ Poverty rate } & \multirow{2}{*}{$\begin{array}{c}\text { Compositional } \\
\text { effect }\end{array}$} & \multirow{2}{*}{$\begin{array}{l}\text { Incidence } \\
\text { effect }\end{array}$} & \multirow{2}{*}{$\begin{array}{c}\text { Total } \\
\text { change in } \\
\text { poverty }\end{array}$} \\
\hline & $1996 / 97$ & $2004 / 05$ & $1996 / 97$ & $2004 / 05$ & & & \\
\hline Born before 1910 & $6.4 \%$ & $0.5 \%$ & $32.7 \%$ & $20.2 \%$ & $-0.2 \%$ & $-0.4 \%$ & $-0.7 \%$ \\
\hline Born 1911-15 & $12.2 \%$ & $3.0 \%$ & $34.8 \%$ & $23.4 \%$ & $-0.6 \%$ & $-0.9 \%$ & $-1.5 \%$ \\
\hline Born 1916-20 & $17.5 \%$ & $9.1 \%$ & $33.6 \%$ & $19.3 \%$ & $-0.3 \%$ & $-1.9 \%$ & $-2.2 \%$ \\
\hline Born 1921-25 & $24.6 \%$ & $16.5 \%$ & $31.6 \%$ & $18.6 \%$ & $-0.1 \%$ & $-2.2 \%$ & $-2.3 \%$ \\
\hline Born 1926-30 & $25.1 \%$ & $19.2 \%$ & $21.8 \%$ & $17.8 \%$ & $+0.2 \%$ & $-0.9 \%$ & $-0.7 \%$ \\
\hline Born 1931-35 & $12.9 \%$ & $22.7 \%$ & $21.8 \%$ & $14.5 \%$ & $-0.4 \%$ & $-1.3 \%$ & $-1.7 \%$ \\
\hline Born 1936-40 & $1.3 \%$ & $21.2 \%$ & $22.7 \%$ & $15.1 \%$ & $-0.7 \%$ & $-0.8 \%$ & $-1.6 \%$ \\
\hline Born 1941-45 & $0.0 \%$ & $7.8 \%$ & $16.1 \%$ & $18.5 \%$ & $-0.4 \%$ & $+0.1 \%$ & $-0.3 \%$ \\
\hline All pensioners & $100 \%$ & $100 \%$ & $27.9 \%$ & $17.0 \%$ & $-2.7 \%$ & $-8.3 \%$ & $-11.0 \%$ \\
\hline
\end{tabular}

Note: Poverty rates are measured as the proportion of the relevant cohort group with income below 60 per cent of the population-wide AHC median income.

Source: Authors' calculations based on Family Resources Survey, various years.

The next two columns in Table 3.6 show the rates of poverty in 1996/97 and 2004/05 within each of these cohort groups. Poverty rates have clearly dropped quite considerably amongst all cohorts (except those born 1941-45, for whom there has been a slight rise). The drop in poverty within cohorts is most pronounced for the two cohorts born 1916-20 and 1921-25. This may be due in part to significantly increased means-tested benefit and tax credit entitlements amongst the older population (see Brewer, Goodman and Leicester (2006) for more detail), but is probably also driven by a differential mortality effect, especially amongst the older cohorts, as richer pensioners tend to live longer than poorer ones.

The last column of Table 3.6 gives the contribution of each cohort to the change in the overall pensioner poverty rate between 1996/97 and 2004/05, whilst the previous two columns decompose this into a 'compositional effect', due to the changing population shares of each cohort, and an 'incidence effect', due to changes in the poverty rates within cohorts.

In total, we can see that the 'incidence effects' dominate: of the total decline of 11.0 percentage points, the drop in poverty rates within cohorts explains 8.3 percentage points, i.e. 75 per cent of the decline in pensioner poverty. These incidence effects are largest for the three cohorts born 1916-20, 1921-25 and 1931-35. It will be important in future work to try to further disentangle how much the incidence effects are driven by differential mortality patterns between cohorts and how much by rising incomes for given individuals within these cohorts.

The overall 'compositional effect' - due to the rising share of the pensioner population accounted for by younger cohorts and the falling share accounted for by older ones - explains 2.7 percentage points of the fall in pensioner poverty, or about 25 per cent of the total fall. This suggests that the government's efforts to reduce pensioner poverty have been helped by 'beneficial' trends in the cohort composition of the pensioner population. This could be the result of either newer cohorts having greater access to private and public resources, or, if a greater proportion of more recent cohorts own their homes outright, lower housing costs (since we are considering poverty measured AHC). 
Table 3.7. Relative working-age non-parent poverty: percentage of workingage non-parents in households with income below various fractions of median income

\begin{tabular}{|c|c|c|c|c|c|c|c|}
\hline & \multicolumn{6}{|c|}{ Percentage of the working-age non-parent population } & \multirow{3}{*}{$\begin{array}{c}\text { Working- } \\
\text { age non- } \\
\text { parent } \\
\text { population } \\
\text { (million) }\end{array}$} \\
\hline & \multicolumn{3}{|c|}{ After housing costs } & \multicolumn{3}{|c|}{ Before housing costs } & \\
\hline & $\begin{array}{c}50 \% \\
\text { median }\end{array}$ & $\begin{array}{l}60 \% \\
\text { median }\end{array}$ & $\begin{array}{c}70 \% \\
\text { median }\end{array}$ & $\begin{array}{c}50 \% \\
\text { median }\end{array}$ & $\begin{array}{l}60 \% \\
\text { median }\end{array}$ & $\begin{array}{c}70 \% \\
\text { median }\end{array}$ & \\
\hline 1996/97 & 12.9 & 17.4 & 21.2 & 7.6 & 12.3 & 17.9 & 20.6 \\
\hline 1997/98 & 11.9 & 16.1 & 20.0 & 7.3 & 12.0 & 17.0 & 20.8 \\
\hline 1998/99 & 11.5 & 15.6 & 19.6 & 7.3 & 11.8 & 16.7 & 20.9 \\
\hline 1999/00 & 12.1 & 16.4 & 20.5 & 7.6 & 12.2 & 17.6 & 21.1 \\
\hline 2000/01 & 12.7 & 16.3 & 20.6 & 8.5 & 12.7 & 17.7 & 21.3 \\
\hline 2001/02 & 12.0 & 15.7 & 19.7 & 7.8 & 12.1 & 16.9 & 21.6 \\
\hline 2002/03 & 12.5 & 16.7 & 20.8 & 8.6 & 12.8 & 17.8 & 21.8 \\
\hline 2003/04 & 13.0 & 16.9 & 21.2 & 8.7 & 12.9 & 18.1 & 21.9 \\
\hline 2004/05 & 12.5 & 16.7 & 20.8 & 8.6 & 12.8 & 18.0 & 21.9 \\
\hline Change: & & & & & & & \\
\hline Since 1996/97 & $(-0.4)$ & $(-0.7)$ & $(-0.4)$ & 1.0 & $(0.5)$ & $(0.1)$ & \\
\hline Since $1998 / 99$ & $(1.0)$ & 1.1 & (1.2) & 1.2 & 1.0 & 1.3 & \\
\hline
\end{tabular}

Notes: Reported changes may not equal the differences between the corresponding percentages due to rounding. Changes in parentheses are not significantly different from zero at the 5 per cent level.

Sources: Authors' calculations based on Family Resources Survey, various years. Population totals are from the HBAI data-set.

Figure 3.9. Cumulative distribution of incomes relative to the median: working-age non-parents only

Working-aged, non-parents $\mathrm{BHC}$ income

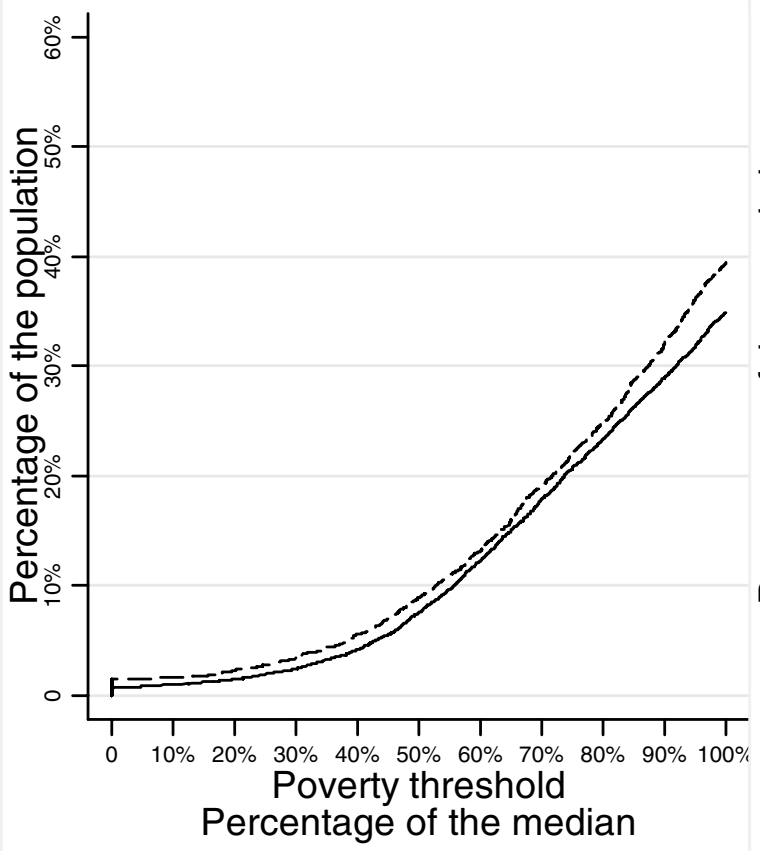

$1996 / 97----2004 / 05$
Working-aged, non-parents $\mathrm{AHC}$ income

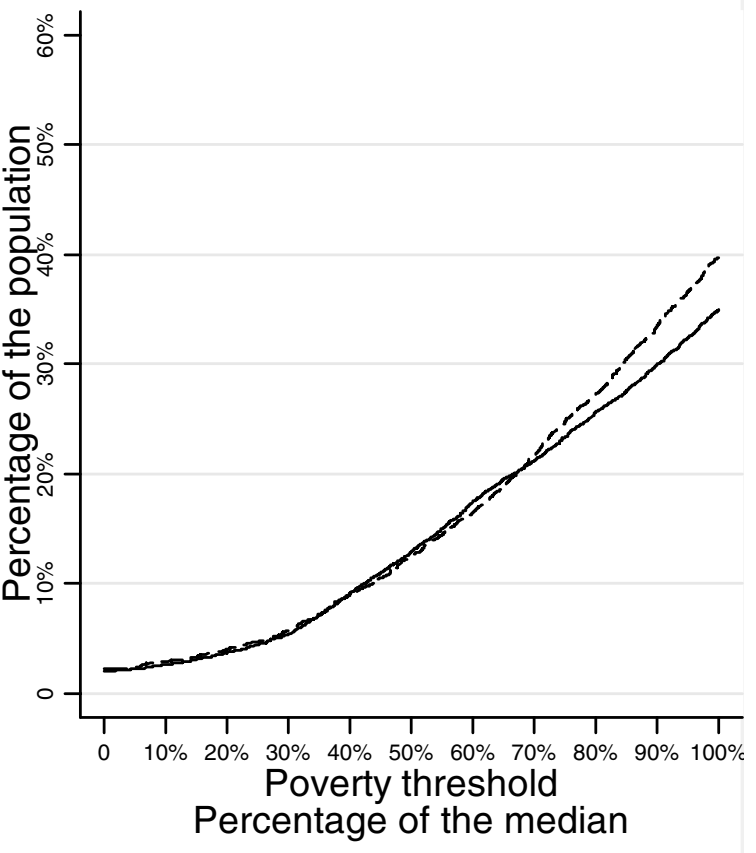

1996/97 - - - 2004/05

Source: Authors' calculations using Family Resources Survey, 1996/97 and 2004/05. 


\subsection{Poverty among other groups}

The government has focused its efforts on reducing poverty amongst families with children and pensioners, presumably because, as Table 3.7 shows, poverty among childless workingage adults is lower than that among pensioners or children. However, unlike poverty amongst pensioners and children, poverty amongst this group, which makes up 39 per cent of the population (21.9 million individuals), has not fallen significantly in recent years. In fact, despite the drop between 2000/01 and 2001/02, there has been a statistically significant increase in poverty since 1998/99.

Figure 3.9 backs this up further by showing the cumulative distribution of incomes relative to the median of this group. It shows that there has been a small increase in poverty among this group against all thresholds below the median when income is measured BHC. Measured $\mathrm{AHC}$, the increase in poverty is only evident for thresholds above around 70 per cent of the median.

\subsection{Conclusion}

With the relative poverty line set at 60 per cent of median income, there are now 11.4 million individuals in poverty measured after housing costs (AHC) and 9.2 million measured before housing costs (BHC), down 2.4 million and 1 million respectively since 1996/97. However, at 16.1 per cent of the population in 2004/05, the BHC poverty rate is still much higher than the 10.9 per cent recorded in 1982 before the steep rise in the 1980s.

Falls in relative poverty have been seen across the family types that have received substantial government attention - families with children and pensioners - whereas the poverty rate for the working-age non-parent population - a group that has received little government attention - has actually risen since 1998/99. The falls in pensioner poverty over recent years have been quite substantial and have resulted from a combination of compositional effects, as new cohorts reach retirement and older ones die out, and incidence effects, as poverty rates have dropped within all pensioner cohorts. Child poverty has fallen by about a fifth since 1998/99, measured both AHC and BHC. However, the fall in child poverty has not been enough to meet the government's 2004/05 target to cut child poverty by a quarter compared with 1998/99. 


\section{Child poverty from $1998 / 99$ to $2004 / 05$ : why did it fall, and why didn't it fall far enough?}

In this chapter, we look in more detail at the government's record in reducing child poverty since 1998/99.

Chapter 3 showed that child poverty has fallen by 700,000 since 1998/99 (measuring incomes AHC or BHC), and it is now at its lowest level since the late 1980s. The trend of rapidly rising child poverty that began in the 1980s has been halted and clearly reversed. This is a remarkable achievement, all the more so since median income has been growing relatively strongly since 1996/97 (see Section 2.1). In Section 4.1, we consider what factors contributed to the recent fall in child poverty, using decomposition analysis.

The Department for Work and Pensions and HM Treasury have a joint Public Service Agreement (PSA) target for the number of children in poverty in 2004/05 to be a quarter lower than its 1998/99 level, using a poverty line of 60 per cent of median income. Measuring poverty AHC, there were 4.1 million children in poverty in 1998/99, so meeting the target required there to be 3.0 million or fewer children in poverty in 2004/05 - a fall of 1.1 million children. Measuring income BHC, 3.1 million children were in poverty in 1998/99, so meeting the target required that 2.3 million children or fewer be in poverty in $2004 / 05$ - a fall of 0.8 million children. In Chapter 3, we showed that the government fell 100,000 children short of meeting the target measuring incomes BHC and 400,000 children short measuring incomes AHC. In Section 4.2, we try to show why the government missed its targets for 2004/05 even though, just over two years ago, the consensus was that the government had done enough to achieve them. Although it is too early to say definitively why past forecasts overpredicted the decline in child poverty, we find that one possible explanation is that estimates of the amount of tax credits received by families with children based on the Family Resources Survey have become increasingly inaccurate compared with estimates based on HMRC's administrative data, with the FRS understating spending on tax credits for families with children by almost $£ 5$ billion in 2004/05.

In Section 4.3, we assess prospects for the government's 2010/11 child poverty target. Section 4.4 concludes, and sets out some lessons for the government.

\subsection{How was the fall in child poverty achieved?}

Figure 4.1 presents levels of child poverty since 1961 and shows that child poverty is at its lowest point since 1989 (AHC) and 1986 (BHC). Moreover, child poverty has now fallen in every year since 1998/99, which is the longest period of sustained falls in child poverty since consistent data on relative poverty rates started to be available (1961). 
Figure 4.1. Relative child poverty: number of children living in households with income below 60 per cent of median income, 1961 - 2004/05

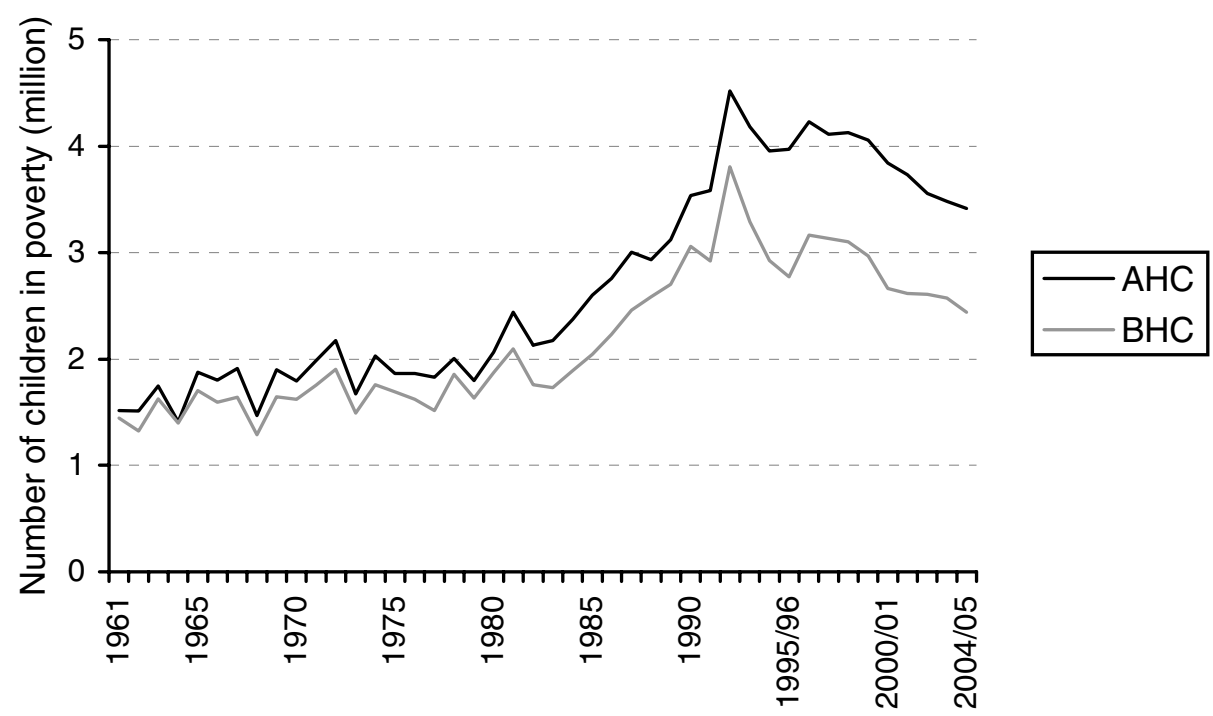

Note: The number of dependent children has fluctuated over this period, so this graph may give a misleading impression of the changing risk of child poverty.

Source: Authors' calculations from HBAI data-sets.

The government can take much credit for this fall in child poverty, both through its decisions to increase substantially the amount of cash transfers made to families with children and through welfare-to-work and other policies that have helped parents in previously workless families to find work and therefore increase their incomes. ${ }^{31}$

In this section, we perform a decomposition analysis which can provide useful insights into why child poverty fell (see Appendix D for details; this sort of decomposition was done in Sutherland, Sefton and Piachaud (2003)). ${ }^{32}$ The principle behind the decomposition is that we would expect child poverty to fall, all other things remaining equal, if

- there were fewer children in 2004/05 than there were in 1998/99;

- children in 2004/05 were more likely (than they were in 1998/99) to live in the types of families with relatively low risks of poverty;

- the risk of poverty for a particular type of family were lower in 2004/05 than in 1998/99.

\footnotetext{
${ }^{31}$ For more detail, see, for example, the chapters in Hills and Stewart (2005), plus Sutherland, Sefton and Piachaud (2003), Sutherland (2002), Brewer, Clark and Goodman (2003), Brewer and Gregg (2003) and Gregg and Harkness (2003). Although many studies have investigated in great detail the extent to which the government's welfare-to-work and tax credit policies have affected labour supply and the incomes of families with children, few have addressed directly the impact of particular policies on child poverty. For example, Brewer and Browne (2006) compare five studies that investigate the impact of recent tax and benefit reforms affecting families with children, but all concentrate on the impact on labour market outcomes and not on poverty outcomes (Francesconi and Van der Klaauw (2004) look at fertility and partnering outcomes). Gregg, Waldfogel and Washbrook (2005), though, look at the impact of the government's reforms affecting families with children on household spending.

${ }^{32}$ The decomposition used here differs from that in Chapter 3 and in Sutherland, Sefton and Piachaud (2003) in that we decompose the change in the number of individuals in poverty, not the proportion. This is because the government's 2004/05 child poverty target is expressed in terms of numbers of children.
} 
Table 4.1. Decomposition of change in relative child poverty (AHC), 1998/99 - 2004/05

\begin{tabular}{|c|c|c|c|c|c|c|c|}
\hline & \multicolumn{2}{|c|}{$\begin{array}{c}\text { Percentage of } \\
\text { child population }\end{array}$} & \multicolumn{2}{|c|}{ Poverty rate (\%) } & \multirow[t]{2}{*}{$\begin{array}{l}\text { Compositional } \\
\text { effect }\end{array}$} & \multirow[t]{2}{*}{$\begin{array}{l}\text { Incidence } \\
\text { effect }\end{array}$} & \multirow{2}{*}{$\begin{array}{c}\text { Total } \\
\text { change in } \\
\text { poverty }\end{array}$} \\
\hline & 1998/99 & $2004 / 05$ & $1998 / 99$ & 2004/05 & & & \\
\hline $\begin{array}{l}\text { Children in lone- } \\
\text { parent families }\end{array}$ & 22.8 & 24.5 & 60.5 & 48.1 & 50,740 & $-370,973$ & $-320,233$ \\
\hline $\begin{array}{l}\text { Children in } \\
\text { couple families }\end{array}$ & 77.2 & 75.5 & 24.2 & 20.4 & 15,634 & $-364,461$ & $-348,827$ \\
\hline \multirow[t]{2}{*}{ All children } & 100.0 & 100.0 & 32.5 & 27.2 & 66,374 & $-735,434$ & $-669,060$ \\
\hline & \multicolumn{2}{|c|}{ Total } & & & & & \\
\hline $\begin{array}{l}\text { Population effect } \\
\text { All changes }\end{array}$ & \multicolumn{2}{|c|}{$12,692,81112,552,021$} & & & & & $\begin{array}{l}-42,057 \\
-711,117\end{array}$ \\
\hline
\end{tabular}

Notes: The table reports unrounded numbers to illustrate the exact nature of the decomposition, but some of the effects are small and may give a spurious impression of accuracy regarding the actual changes in child poverty that have taken place. Rows and columns may not sum exactly to totals due to rounding.

Source: Authors' calculations from various HBAI data-sets.

Table 4.1 presents a simple example of such a decomposition by considering children in loneparent families separately from those in couple families. Specifically, it shows, for the period $1998 / 99$ to $2004 / 05$, the change in the number of children, the change in the proportion of children who were in lone-parent families and the change in the risk of poverty for children in lone-parent and couple families. The table shows changes in poverty measuring incomes AHC; Table E. 1 in Appendix E is the equivalent table for poverty measuring incomes BHC. We focus on poverty measuring incomes AHC partly because we regard it as a better measure of poverty than using incomes BHC, partly because government statements used to place greater weight on poverty measuring incomes AHC than BHC, and partly because the government has missed its target by a greater margin measuring incomes AHC than measuring them $\mathrm{BHC}$.

Table 4.1 shows that

- the number of children in Great Britain fell by around 140,000 between 1998/99 and 2004/05;

- the proportion of children in lone-parent families has risen by 1.6 percentage points since $1998 / 99,{ }^{33}$ reaching 24.5 per cent by $2004 / 05$;

- the poverty rate for children in lone-parent families was around two-and-a-half times as high as that for children in couple families in 1998/99, but both rates have fallen by around a fifth, to 48.1 per cent and 20.4 per cent respectively.

The final three columns of the table use these numbers to decompose the fall in child poverty of just over 700,000 between 1998/99 and 2004/05 into the population effect, the incidence effect and the compositional effect:

\footnotetext{
${ }^{33}$ This rise is not the same as the difference between the percentages in Table 4.1, due to rounding.
} 
- The size of the population effect depends on the overall change in the number of children and on the average poverty risk. The table shows that the fall in the number of children reduced child poverty by around 42,000 .

- The size of the incidence effect for a particular type of family depends on how much the risk of child poverty has changed for that type of family and on what proportion of children live in families of that type; it is always negative for any type of family where the risk of poverty has fallen. Between 1998/99 and 2004/05, the falling risk of child poverty in lone-parent families reduced child poverty by around 370,000 and the falling risk in couple families reduced it by around 365,000.

- The size of the compositional effect for a particular type of family depends on whether the proportion of children in that family type has risen or fallen and on whether the poverty risk for that family type is greater or less than the average poverty risk for all children. Between 1998/99 and 2004/05, the small shift from couple families with children to lone-parent families increased child poverty by around 66,000 .

This simple decomposition tells us, then, that the fall in child poverty between 1998/99 and 2004/05 was due to a falling risk of poverty within both lone-parent families and couple

Table 4.2. Decomposition of change in relative child poverty $(\mathrm{AHC})$, $1998 / 99-2004 / 05$

\begin{tabular}{|c|c|c|c|c|c|c|c|}
\hline & \multicolumn{2}{|c|}{$\begin{array}{l}\text { Percentage of } \\
\text { child population }\end{array}$} & \multicolumn{2}{|c|}{ Poverty rate (\%) } & \multirow[t]{2}{*}{$\begin{array}{c}\text { Compositional } \\
\text { effect }\end{array}$} & \multirow[t]{2}{*}{$\begin{array}{c}\text { Incidence } \\
\text { effect }\end{array}$} & \multirow{2}{*}{$\begin{array}{c}\text { Total } \\
\text { change in } \\
\text { poverty }\end{array}$} \\
\hline & $1998 / 99$ & $2004 / 05$ & 1998/99 & $2004 / 05$ & & & \\
\hline \multicolumn{8}{|l|}{$\begin{array}{l}\text { Children in lone- } \\
\text { parent families }\end{array}$} \\
\hline Full-time & 4.0 & 4.7 & 16.9 & 13.0 & $-14,501$ & $-21,255$ & $-35,756$ \\
\hline Part-time & 5.0 & 7.0 & 44.8 & 27.4 & 15,048 & $-132,117$ & $-117,070$ \\
\hline Workless & 13.8 & 12.8 & 78.7 & 72.3 & $-59,967$ & $-107,440$ & $-167,407$ \\
\hline \multicolumn{8}{|l|}{$\begin{array}{l}\text { Children in } \\
\text { couple families }\end{array}$} \\
\hline Self-employed & 11.5 & 11.8 & 30.5 & 28.6 & -129 & $-26,738$ & $-26,867$ \\
\hline $\begin{array}{r}\text { Two full-time } \\
\text { earners }\end{array}$ & 11.2 & 11.6 & 1.1 & 2.1 & $-15,712$ & 14,146 & $-1,567$ \\
\hline $\begin{array}{l}\text { One full-time, } \\
\text { one part-time }\end{array}$ & 25.0 & 23.8 & 6.7 & 6.5 & 35,441 & $-8,151$ & 27,290 \\
\hline $\begin{array}{l}\text { One full-time, } \\
\text { one not working }\end{array}$ & 18.0 & 17.7 & 27.8 & 21.0 & 2,148 & $-154,379$ & $-152,232$ \\
\hline $\begin{array}{l}\text { One or two } \\
\text { part-time }\end{array}$ & 4.3 & 4.5 & 57.4 & 48.6 & 5,175 & $-48,715$ & $-43,540$ \\
\hline Workless & 7.2 & 6.1 & 82.2 & 71.7 & $-63,157$ & $-88,755$ & $-151,912$ \\
\hline \multirow[t]{2}{*}{ All children } & 100.0 & 100.0 & 32.5 & 27.2 & $-95,655$ & $-573,405$ & $-669,060$ \\
\hline & \multicolumn{2}{|c|}{ Total } & & & & & \\
\hline $\begin{array}{l}\text { Population effect } \\
\text { All changes }\end{array}$ & $12,692,811$ & $12,552,021$ & & & & & $\begin{array}{l}-42,057 \\
-711,117\end{array}$ \\
\hline
\end{tabular}

Notes: The table reports unrounded numbers to illustrate the exact nature of the decomposition, but some of the effects are small and may give a spurious impression of accuracy regarding the actual changes in child poverty that have taken place. Rows and columns may not sum exactly to totals due to rounding.

Source: Authors' calculations from various HBAI data-sets. 
families with children, and came about despite an increased proportion of children living in lone-parent families. ${ }^{34}$

We can learn a lot more, though, by considering child poverty separately for a greater number of family types, taking into account parents' work patterns. In Table 4.2, we show child poverty separately for nine types of families: three sorts of lone-parent families (classified by whether the parent is working full-time (31 or more hours' paid work a week), part-time (less than 31 hours) or workless) and six sorts of couple families with children (classified by whether any parent is self-employed or whether the family contains two full-time workers, one full-time worker and one part-time worker, one full-time worker and one not working, one or two part-time workers or two non-workers). ${ }^{35}$

Table 4.2 contains a great deal of information; below, we discuss what it tells us about

- changes in the types of families in which children live;

- changes in the risk of poverty for children in different types of families;

- the main factors behind the fall in child poverty since 1998/99.

\section{Changes in the types of families in which children live}

Amongst lone-parent families, the proportion of children in workless families has fallen whilst the proportion of children in working - particularly part-time working - families has risen. $^{36}$

Amongst couple families, the changes in work patterns are more complicated, and they are partially obscured by the fact that the proportion of children in couple families has declined. The main changes are falls in the proportions of children in workless couple families and in families with one full-time and one part-time worker (although the latter remains the most common family type in this nine-way split), and small increases in the proportions of children in self-employed families and in couples with two full-time earners.

\section{Changes in the risk of poverty for children in different types of families}

Poverty rates are highest for children in workless families, at over 70 per cent even in 2004/05 (AHC). Other than this family type, children in couple families with no full-time workers are more likely than average to be poor, whereas poverty rates for children in full-time working lone-parent families, couple families with two full-time earners and couple families with one full-time and one part-time earner are well below the average for all children.

Amongst lone parents, poverty rates have fallen for all three family types, but particularly for children whose lone parent works part-time. Amongst children in couple families, poverty

\footnotetext{
${ }^{34}$ Table E.1 in Appendix E shows that the pattern is roughly the same if we decompose child poverty measuring income $\mathrm{BHC}$, but the incidence effect is more important for children in couple families than for children in lone-parent families measuring incomes BHC.

${ }^{35}$ These categories are used in parts of the official HBAl report: see Department for Work and Pensions (2005b, appendix 1). See Table E.2 in Appendix $E$ for the equivalent decomposition measuring income BHC.

${ }^{36}$ Gregg and Harkness (2003) attribute much of this fall to the government's welfare-to-work and tax credit policies, and other studies have similar findings: see Brewer and Browne (2006).
} 
rates have fallen for all family types except the two-full-time-earners category (where the risk of poverty has doubled from an insignificant 1 per cent to 2 per cent); the biggest falls in poverty in percentage point terms have been amongst workless and one-earner couple families.

\section{Decomposing the changes in child poverty}

Table 4.2 shows that both the compositional and the incidence effects (summed across all nine family types) have acted to reduce child poverty, with the compositional effect accounting for just under 100,000 children (13.5 per cent of the total fall) and the incidence effect for around 575,000 (80.6 per cent; the remaining 5.9 per cent is due to the population effect).

This is a different conclusion from that for Table 4.1, where the compositional effect (more children in lone-parent families) worsened child poverty. The difference arises because Table 4.2 uses a more detailed disaggregation, and so some of the changes in child poverty attributed to incidence effects in Table 4.1 are attributed to compositional effects in Table 4.2. ${ }^{37}$ For example, the poverty risk for children in all lone-parent families fell partly because a greater proportion of lone parents are now working, and working lone parents have a much lower risk of poverty than non-working lone parents.

The compositional effects in Table 4.2 tend to be smaller in magnitude than the incidence effects. Although the sum of all nine compositional effects is negative, some of the individual numbers are positive, so some compositional changes acted to increase child poverty. The two most important beneficial compositional effects - those that acted to reduce child poverty arise from the fall in the proportion of children in workless families, both lone-parent and couple families: these family types have very high risks of poverty. The adverse compositional changes - those that acted to increase child poverty - are for children with part-time working lone parents, children in working couples with only part-time earners and children in couples with one full-time and one part-time earner. ${ }^{38}$

All but one of the incidence effects in Table 4.2 are negative, because poverty rates have fallen for eight of the nine family types; couple families with two full-time earners are the exception. The three largest incidence effects are for one-full-time-earner couples, part-time working lone-parent families and workless lone-parent families. This pattern is consistent with the direction of the government's tax and benefit changes affecting families with children, because these families in particular have benefited from increases in childcontingent support through tax credits and out-of-work benefits. ${ }^{39}$

\footnotetext{
${ }^{37}$ This means that the sum of all incidence effects in Table 4.1 need not match the sum of all incidence effects in Table 4.2; the population effect, though, is the same in all tables, as is (by definition), the overall change in child poverty that is being explained.

${ }^{38}$ The first two of these family types have seen their population shares increase, and the compositional effect is positive (i.e. has increased child poverty) because these family types have higher-than-average rates of child poverty. On the other hand, the proportion of children who live in couples with one full-time and one part-time earner has fallen since 1998/99, and this produces an adverse compositional effect because such children have lower-thanaverage rates of child poverty.

${ }^{39}$ See Brewer and Shephard (2004) or Adam and Wakefield (2005).
} 
To summarise a complicated set of changes, child poverty fell primarily because

- there were large falls in the risk of poverty for children in workless families, those with part-time working lone parents and those in couple families with one full-time parent and one non-working parent;

- there was a substantial decline in the proportion of children living in workless families.

\subsection{Why did the government miss its child poverty target for 2004/05?}

The decline in child poverty between 1998/99 and 2004/05, while substantial, fell short of the government's target to reduce it by a quarter. This is despite a consensus in early 2004 between independent researchers and civil servants that the government had done enough to meet its target. In this section, we try to identify the main reasons why child poverty remains higher than was expected. We first revisit the assessments - made in late 2003 and early 2004 - that the government was on track to meet its targets. We then offer some hypotheses about why the central forecasts proved to be incorrect.

\section{Past predictions of child poverty in 2004/05}

The rates of benefits and tax credits that applied during 2004/05 had to be announced by the government no later than the Pre-Budget Report in December 2003. This was the last realistic opportunity that the government had to influence the level of child poverty in 2004/05, and it was therefore the earliest opportunity that one could assess definitively whether government policies looked sufficient for the target to be met. Assessments were made by both independent analysts and civil servants:

- Before the 2003 Pre-Budget Report, the central forecast presented in Brewer (2003) was that the government would fall short of its target in 2004/05 measuring incomes AHC unless it announced an increase in child-contingent support from April 2004.

- In the 2003 Pre-Budget Report, the Chancellor announced an increase in the per-child element of the child tax credit in April 2004 of $£ 3.50$ a week. HM Treasury (2003, para. 5.20) said that

As a result of this new investment, the Government is on track to meet or exceed its PSA target to reduce by a quarter the number of children in low-income households by 2004-05 on a BHC basis ... The target is more challenging on an AHC basis. The nature of the target means that there are uncertainties either way. Analysis by the Institute for Fiscal Studies suggests that this increase will enable the Government to make substantial progress on an AHC basis.

As well as referring to our work, it is our understanding that this assessment also drew on a forecast of child poverty made by officials in HM Treasury.

- After the 2003 Pre-Budget Report, Brewer (2004, p. 5) concluded that 'the government should comfortably meet its target measuring incomes BHC, and is on course to just hit its target measuring incomes AHC'. 
- Based on research completed before the increase in the child tax credit announced in the 2003 Pre-Budget Report, Sutherland, Sefton and Piachaud (2003, p. 62) concluded that 'our estimate is thus that child poverty will be about a quarter below its 1998/9 level by 2004, in line with the government's target, unless other factors change in an unfavourable direction in which case more redistributive measures will be needed'.

All of these assessments were based on forecasts of the level of child poverty using microsimulation models. ${ }^{40}$ At the time the forecasts were made, the latest data available on child poverty related to 2001/02, and so the challenge was to forecast how child poverty would change between 2001/02 and 2004/05, based both on what was known about future tax and benefit policy and on predictions of key economic and socio-demographic trends that determine child poverty. In the next subsection, we discuss how the forecasts of the fall in child poverty compare with what actually happened.

\section{What happened to child poverty after 2001/02, and where did the forecasts go wrong?}

By Spring 2005, data on child poverty in 2002/03 and 2003/04 had become available. The fall in child poverty between 2002/03 and 2003/04 was considerably smaller than anticipated by researchers at IFS, given the substantial increase in the generosity of the child and working tax credits compared with the working families' tax credit and other programmes that were replaced by the child tax credit. Based on this new information, Brewer et al. (2005, p. 43) concluded that

On balance, though, child poverty should fall in 2004/05. Sampling error means that little can be inferred with certainty from a single year's data, but the likelihood that the government will hit its targets seems a little lower now than it was a year ago. Measured BHC, child poverty should probably fall to levels close to the government's target; measured AHC, though, the issues identified above do not alone seem sufficient for child poverty to meet its target.

In this section, we look further at what happened to child poverty after 2001/02 and consider where the previously optimistic forecasts went wrong.

\section{Decomposing the change in child poverty between 2001/02 and 2004/05}

As already discussed, all three forecasts of child poverty in 2004/05 described above were ultimately based on a forecast of the change in child poverty between 2001/02 and 2004/05. It is therefore possible to compare the forecast fall in child poverty with how child poverty actually fell.

Table E.5 in Appendix E presents the results of a decomposition of the change in child poverty between 2001/02 and 2004/05 using the same nine categories as in Table 4.2. This decomposition shows that almost all the fall in child poverty between 2001/02 and 2004/05 can be attributed to incidence effects. ${ }^{41}$ Although there were two important compositional

\footnotetext{
${ }^{40}$ A microsimulation model typically incorporates a set of rules that estimate liability to taxes and entitlement to benefits and tax credits; these rules are then applied to information collected on a representative sample of households in a large survey. The three different models used inside government, by Professor Sutherland and by researchers at IFS are all based on the Family Resources Survey, the same data-set used to derive the HBAI data.

${ }^{41}$ Section 4.1 showed, though, that the split between incidence and compositional changes is sensitive to the choice of different family types.
} 
changes - a shift from workless lone parents to part-time working lone parents and a shift from couples with at least one full-time earner to those with no full-time earners - the impacts on child poverty were of opposite sign and roughly balance out. (Appendix F looks at changes in work patterns and child poverty more generally.)

The fact that there are very small net compositional effects makes it easy to compare the actual changes in child poverty with those that were predicted by Brewer (2004): the forecast of child poverty made by Brewer assumed that there would be no change in household composition or work patterns, and so, by definition, assumed that there would be no compositional effect on the level of child poverty. In Table 4.3, we therefore compare the predicted incidence effects with the actual incidence effects.

The table shows that, having abstracted from population and compositional effects, child poverty in 2004/05 is around 375,000 higher than predicted by Brewer (2004) measuring incomes AHC. The central forecast in Brewer (2004) overpredicted the fall in child poverty for all family types except couples with one or two part-time workers and workless couples. Just over half (51 per cent) of the net overprediction/shortfall comes from children in workless lone-parent families, and the next most important family types are couples where one adult works full-time and then self-employed couples. ${ }^{42}$

Table 4.3. Actual and forecast incidence effects for the change in child poverty (AHC), 2001/02 - 2004/05

\begin{tabular}{r|ccc}
\hline & Predicted & Actual & Difference \\
\hline Cull-time & $-13,884$ & 7,538 & 21,422 \\
Part-time & $-99,115$ & $-96,054$ & 3,061 \\
Workless & $-249,748$ & $-57,455$ & 192,293 \\
Children in couple families & & & \\
Self-employed & $-54,767$ & 13,207 & 67,974 \\
Two full-time earners & 0 & 11,287 & 11,287 \\
One full-time, one part-time & $-36,305$ & $-15,996$ & 20,309 \\
One full-time, one not working & $-97,088$ & $-20,400$ & 76,688 \\
One or two part-time & $-55,196$ & $-56,216$ & $-1,020$ \\
Workless & $-61,204$ & $-79,007$ & $-17,803$ \\
\hline All changes ramilies & $-667,308$ & $-293,097$ & 374,211 \\
\hline
\end{tabular}

Notes: The table reports unrounded numbers to illustrate the exact nature of the decomposition, but some of the effects are small and may give a spurious impression of accuracy regarding the actual changes in child poverty that have taken place. Columns may not sum exactly to totals due to rounding.

Source: Authors' calculations from various HBAI data-sets and own calculations based on TAXBEN. A positive 'difference' means that child poverty fell by less than expected (or rose by more than expected). The predicted incidence effects have been calculated as the predicted change in child poverty for children in the nine family types multiplied by the number of children in each group in 2001/02. This table uses data from Brewer (2004).

\footnotetext{
${ }^{42}$ Measuring incomes BHC, Table E.4 in Appendix E shows that, although child poverty measuring incomes BHC is closer to its target than measuring incomes AHC, the difference from the predicted level of child poverty is greater: around 450,000 . Children in workless families (regardless of how many adults) make up over three-quarters (77 per cent) of the overprediction/shortfall measuring incomes BHC.
} 


\section{Why were the forecasts of child poverty wrong?}

Ultimately, it is too early to tell why child poverty in 2004/05 is considerably higher than forecast two years ago. Given time to analyse the 2004/05 FRS in detail, there will be lessons to be learnt by those using microsimulation models to forecast changes in poverty. However, a number of remarks can already be made.

It seems unlikely that an idiosyncratic programming error was to blame for the poor performance of the original forecasts. The conclusion that the government had done enough to meet its child poverty targets was reached independently, using different microsimulation models, by two teams of researchers outside government and by civil servants in HM Treasury. A more plausible explanation relates to the uncertainty surrounding economic projections. In the case of forecasting child poverty, these uncertainties arise from the following:

(i) Sampling error: Both the forecast of child poverty and the eventual estimate of child poverty are based upon a large survey of households, and so the estimates of child poverty are subject to sampling error. (However, Chapter 3 showed that our estimate of the standard error around estimates of child poverty is around 80,000, and so the level of child poverty in 2004/05 is statistically significantly different from the central forecasts in Brewer (2004), measuring incomes both AHC and BHC.)

(ii) The need to make assumptions about future changes in financial variables (such as private earnings, rents and council tax) and about socio-demographic and economic trends that affect child poverty (such as the number and composition of households, fertility, housing tenure and work patterns): The forecasts made by Brewer (2004) used the neutral assumptions that the basic demographic structure of the population did not change between 2001/02 and 2004/05 but that financial variables would increase in line with forecasts of various indices. ${ }^{43}$

(iii) The need to predict families' eventual receipt of tax credits and state benefits, given estimates of their entitlements: The forecasts made by Brewer (2004) used the assumption that any benefit or tax credit entitlements additional to those implied by the 2001/02 tax and benefit system (above those due just to inflation) would be taken up in full. However, the forecasts implicitly allowed for some non-take-up of entitlements to benefits and tax credits under the 2001/02 tax and benefit system.

(iv) The need to simulate behavioural responses to changes to taxes, tax credits and means-tested benefits: The forecasts made by Brewer (2004) assumed that the changes in taxes and benefits between 2001/02 and 2004/05 would not affect work patterns.

\footnotetext{
${ }^{43}$ For example, predictions made by Brewer (2003 and 2004) assumed no change in employment patterns or household composition, and contained separate forecasts for the level of earnings, self-employment profits, nonearned income, rent levels, mortgage interest payments and council tax levels. These are either based on official forecasts of the same, or extrapolate past medium-run trends. Sutherland, Sefton and Piachaud (2003) give some details of the key assumptions underpinning their estimates, but it is not known what assumptions were made by HM Treasury when making its forecast.
} 
These uncertainties are particularly relevant when forecasting changes in child poverty because many children are located close to the poverty line: in 2004/05, for example, 800,000 children were living in households within 5 per cent of the poverty line, measuring incomes AHC. This means that small errors in forecasting median income, or the incomes of lowincome households with children, can have large effects on estimates of child poverty, and correspondingly larger proportional effects on estimates of the change in child poverty.

We have not had time to investigate in any detail the four issues identified above, but two factors that relate specifically to (iii) seem likely to be important.

First, the assumption about take-up of the child tax credit made in Brewer (2004) may have been too optimistic, thereby overstating the predicted fall in child poverty. In last year's HBAI Commentary (Brewer et al., 2005), we argued that the simulation was consistent with an increase in take-up of tax credits. Official estimates for take-up of tax credits in 2004/05 are not yet available, and those for 2003/04 are due to be released while this report is in press (HM Revenue \& Customs, 2006).

Second, the FRS has continued to under-record receipt of tax credits (or equivalent in out-ofwork benefits), and this problem appears to have worsened over time. Box 4.1 describes the extent of this under-recording, while Brewer and Shaw (2006) analyse this issue in more detail. Given that the proportion of expenditure on tax credits captured by the FRS has worsened since $2001 / 02$ - the gap was close to $£ 5$ billion by $2004 / 05$, representing almost a third of total tax credit spending - much of the new money put into tax credits since 2001/02 may have acted to reduce child poverty in the microsimulation forecasts but not been reflected in actual estimates of child poverty. This has important implications for the way the government chooses to measure poverty, particularly since tax credits now comprise the majority of child-contingent support: see Adam and Brewer (2004).

Brewer et al. (2005) highlighted two additional reasons why child poverty might have fallen less than expected between 2002/03 and 2003/04. However, it is now apparent that these were one-offs: we do not think that these factors contributed to the failure to meet the child poverty target in 2004/05. These factors were as follows:

- There were considerable administrative difficulties when tax credits were introduced in April 2003, and these led to a large proportion of individuals in the first few months of 2003/04 waiting to have their tax credit claim processed. This phenomenon does not seem to have occurred in 2004/05.

- There was a rise in the proportion of children in workless families in the FRS between $2002 / 03$ and 2003/04. However, the proportion of children in workless families changed little between 2001/02 and 2004/05, in line with the assumptions made in Brewer (2004) (see Appendix F). 


\section{Box 4.1. Under-reporting of tax credits in the FRS}

Figure 4.2 compares estimates of tax credit receipt among families with children derived from the FRS with those based on HMRC's administrative data. The series 'Number of families with children receiving' includes families receiving tax credits (or equivalent in out-of-work benefits) or in-work support. The series 'Total spending' includes spending on tax credits and in-work support (not out-of-work benefits). The graph shows the following:

- The FRS has under-reported both the number of recipients and expenditure since (at least) $1997 / 98$. $^{\text {a }}$

- Since 1999/2000, the FRS has moved closer to the administrative data when estimating the number of recipients, but there still remains a gap of roughly 15 per cent. (The downward blip in 2003/04 coincides with when the child tax credit and working tax credit were first introduced).

- The FRS has moved further away from the administrative data when estimating spending, capturing less than 70 per cent of the administrative total in the most recent two years. ${ }^{\text {b }}$

Figure 4.2. Comparing estimates of tax credit receipt amongst families with children in Great Britain, 1997/98 - 2004/05

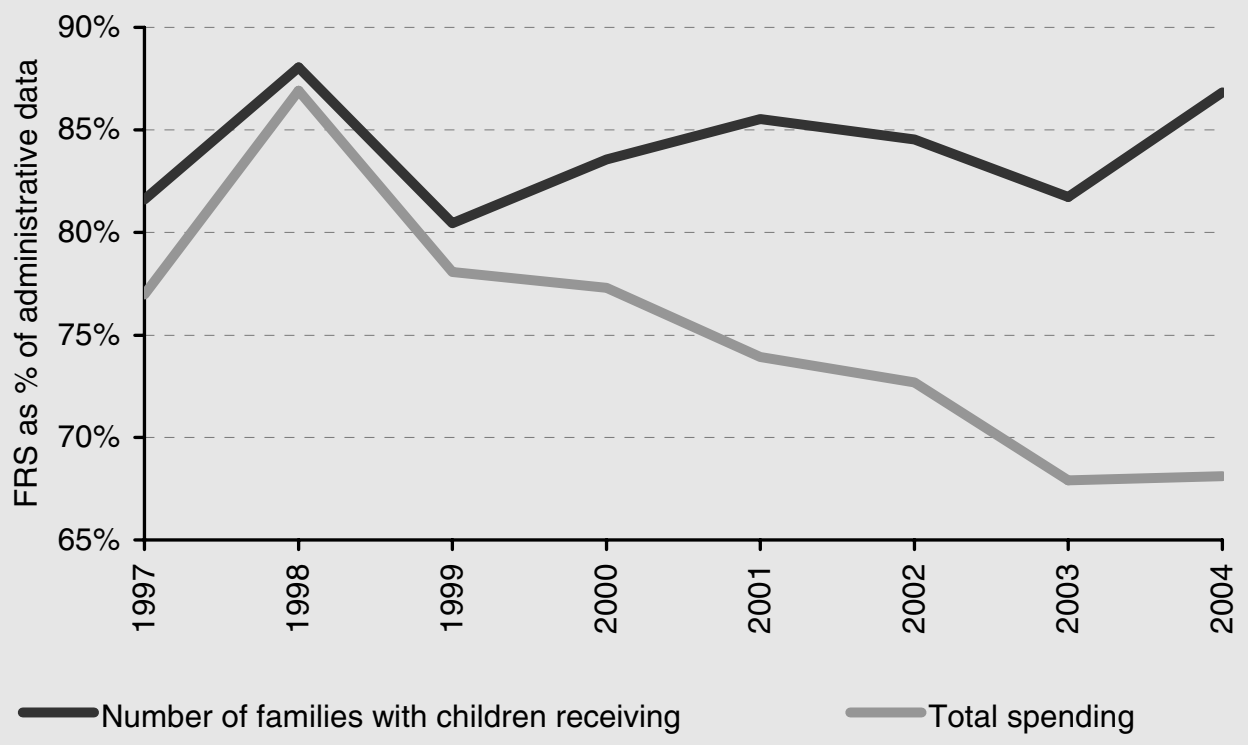

Notes: The graph shows estimates based on the FRS as a percentage of equivalent estimates based on administrative data. Years refer to financial years, so 1997 means 1997/98, for example. The series labelled 'Number of families with children receiving' measures the following: up to and including 2002/03, the estimated number of recipients of working families' tax credit (WFTC) or family credit in the FRS as a percentage of equivalent estimates from administrative data; from 2003/04 onwards, the estimated number of families with children receiving child tax credit or income support in the FRS as a percentage of estimated number of families with children receiving child tax credit or equivalent in out-of-work benefits from administrative data. The series labelled 'Total spending' compares estimated expenditure on tax credits (not out-of-work benefits) and family credit for families with children in the FRS as a percentage of equivalent estimates from administrative data. All estimates from the FRS apply to Great Britain, so estimates from administrative data have been adjusted so they are applicable to Great Britain, and only to tax credits for families with children (contact authors for details).

Sources: Authors' calculations based on: Family Resources Survey (various years); Department of Social Security (various years); HM Revenue \& Customs (2005c and earlier years) (spend on tax credits); HM Revenue \& Customs (2005b) (to estimate the proportion of tax credits spent on those without children in Great Britain); HM Revenue \& Customs (2005a) and Inland Revenue (2003b) (families receiving tax credits or equivalent in out-of-work benefits). 
Table 4.4 provides information for 2003/04 and 2004/05 in more detail. In particular, it shows that the FRS underestimates total spending on tax credits for families with children in Great Britain by $£ 4$ billion in 2003/04 and almost $£ 5$ billion in 2004/05.

Table 4.4. Comparing estimates of tax credit receipt amongst families with children in Great Britain

\begin{tabular}{|c|c|c|c|c|c|}
\hline & \multicolumn{2}{|c|}{$\begin{array}{l}\text { Spending on } \\
\text { tax credits }\end{array}$} & \multicolumn{3}{|c|}{$\begin{array}{l}\text { Families with children receiving tax credits } \\
\text { or equivalent out-of-work benefits }\end{array}$} \\
\hline & $2003 / 04$ & $2004 / 05$ & 2003/04 & $\begin{array}{c}2003 / 04 \\
\text { including } \\
\text { those } \\
\text { waiting for a } \\
\text { claim }\end{array}$ & $2004 / 05$ \\
\hline $\begin{array}{l}\text { Administrative } \\
\text { data }\end{array}$ & $£ 12.8 \mathrm{bn}$ & $£ 14.9 \mathrm{bn}$ & $5.4 \mathrm{~m}$ & $n / a$ & $5.5 \mathrm{~m}$ \\
\hline FRS & $£ 8.7 \mathrm{bn}$ & $£ 10.1 \mathrm{bn}$ & $4.4 \mathrm{~m}$ & $4.9 \mathrm{~m}$ & $4.7 \mathrm{~m}$ \\
\hline Difference & $£ 4.1 \mathrm{bn}$ & $£ 4.8 \mathrm{bn}$ & $1.0 \mathrm{~m}$ & $n / a$ & $0.7 \mathrm{~m}$ \\
\hline
\end{tabular}

Notes and sources: As Figure 4.2.

It is highly likely that the FRS does not record tax credits paid to families as one-off payments (these payments usually occur when there has been an underpayment (see Brewer (2006) for more details). This will particularly affect the estimate of total spending on tax credits in 2003/04 based on the FRS, because administrative problems in the first months of that year meant that a large proportion of families interviewed by the FRS in April to June 2003 were still waiting to receive tax credits; when these families were finally paid tax credits, they would have received a back-payment covering those months. The problem may also affect the estimate for 2004/05, but it is not clear what proportion of tax credits are paid out as one-off payments.

${ }^{a}$ This means that the failure of the FRS to record enough tax credit recipients is not in itself a valid reason for the child poverty targets not being met. Because the FRS has always underestimated the number of recipients, it may well have always overestimated the level of child poverty.

${ }^{\mathrm{b}}$ We considered the possibility that some families with children receiving both income support and child tax credit might mistakenly report their income from tax credits as income support, but estimates of the total spend on income support for families with children in 2003/04 and 2004/05 based on the FRS are below comparable estimates made by the Department for Work and Pensions (contact authors for details).

\subsection{The prospects for child poverty in $2010 / 11$}

The 2004/05 child poverty target is just the first of three targets that the government has committed itself to meeting by 2020 , the other two being to cut child poverty by 50 per cent by $2010 / 11$ and to have 'effectively eradicated' it by 2020 . The $2010 / 11$ target will be 
assessed using a combination of relative poverty, measured BHC, and material deprivation measures. In this section, we examine the government's ability to meet the relative poverty element of the 2010/11 target. $^{44}$

The fact that child poverty did not fall by a quarter between 1998/99 and 2004/05 will make it all the more challenging to ensure that it is reduced by a half by 2010/11. However, there are two changes to the way that child poverty will be measured for the purposes of the 2010/11 target that must be considered. First, it may be measured on a UK basis rather than just looking at Great Britain. Although this would raise the total number of children in poverty, ${ }^{45}$ the 1998/99 baseline would also be revised upwards, so this is unlikely to make much difference to the feasibility of meeting the target. More importantly, as was referred to in Chapter 1, the 2010/11 target will be assessed using the new Modified OECD equivalence scales. As Appendix A shows, the number of children in poverty is higher every year when using these than when using the McClements scale. Furthermore, the proportionate decline in child poverty since 1998/99 is slightly smaller using the new equivalence scales, so that had the government used the new equivalence scales this year, the target would have been missed by even more (over 200,000). As a result, child poverty now has to fall by about 1 million between 2004/05 and 2010/11 in order to meet the target - over one-and-a-half times greater than the 600,000 fall between 1998/99 and 2004/05 (using the Modified OECD scale).

The demanding nature of the 2010/11 target is further demonstrated by Figure 4.3, which shows the path of child poverty between 1998/99 and 2004/05, together with a projected path for child poverty up to 2010/11 and the path required to meet the 2010/11 target. The projected path is calculated using the average annual fall in child poverty between 1998/99 and 2004/05, whilst the required path is drawn as the path that would achieve the target based on equal reductions each year since 1998/99. The graph shows that if the actual level of child poverty falls between 2004/05 and 2010/11 by the same amount per annum as it has on average in the six years since 1998/99, then the target will be missed by about 400,000 .

With this in mind, researchers from IFS and other institutions are currently engaged in a project funded by the Joseph Rowntree Foundation (JRF) that is looking at what might happen to child poverty by 2010 and 2020 on current policies. They will assess the likely implications of any rise in parental employment, and estimate the cost of meeting the government's targets using different reforms to taxes, tax credits and benefits (see www.jrf.org.uk/knowledge/wip/record.asp?ID=804080). The work is due to complete by Summer 2006.

Although that work is still ongoing, some conclusions can be reached now. First, in the absence of new spending initiatives, there is a tendency for relative child poverty to rise each year. This is because most benefits and tax credits rise in line with prices, whereas median income (and therefore the poverty line) tends to rise faster, at roughly the same rate as

\footnotetext{
${ }^{44}$ See Department for Work and Pensions (2003). We do not consider the material deprivation element of the 2010/11 target here both because this has not yet been fully defined by the government and because we were not given access to the material deprivation elements of the FRS for this Commentary. The 2020 target is also yet to be fully defined.

${ }^{45}$ In 2004/05, there were only 750,000 children in total in Northern Ireland. However, another problem might be the fact that the poverty threshold is lower as a result of lower median income when including Northern Ireland, though again this is unlikely to affect median incomes differentially across years.
} 
Figure 4.3. Actual, projected and required path of child poverty, $1998 / 99-2010 / 11$

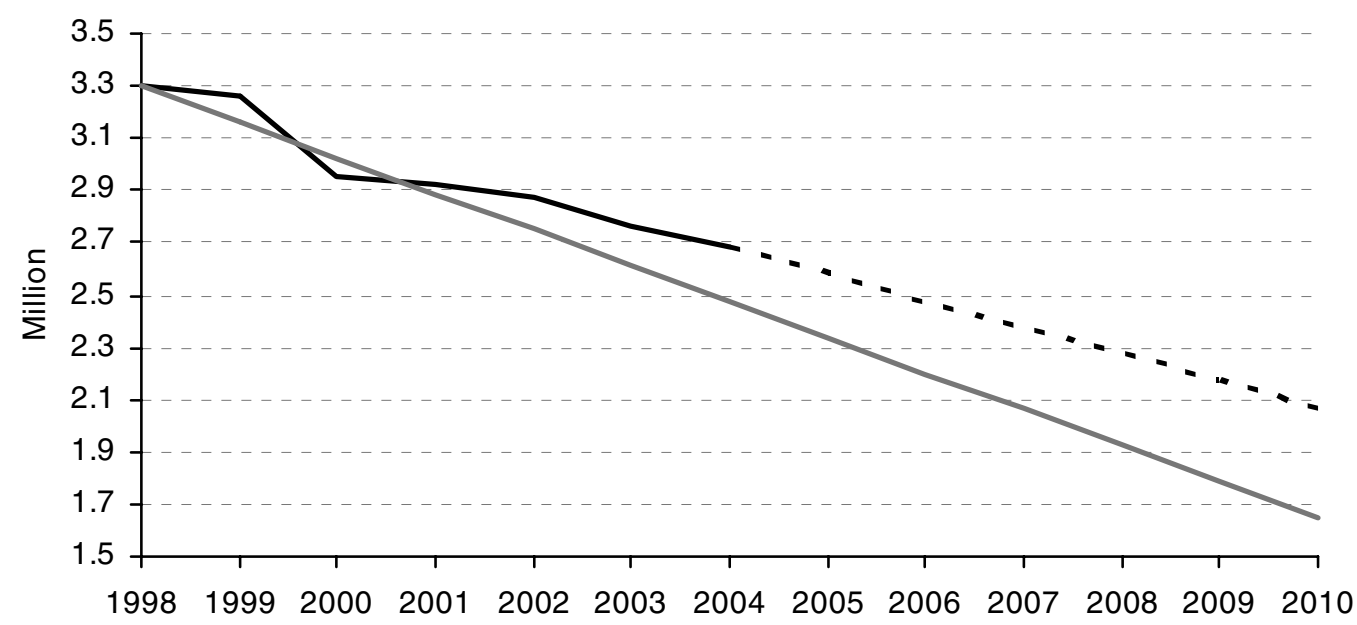

—Child poverty - - - - Projected path — Required path

Note: Years are financial years (e.g. 1998 refers to financial year 1998/99).

Source: Authors' calculations based on the Family Resources Survey, various years.

average earnings. In the absence of beneficial economic or demographic trends, this will mean that the total income of low-income households with children will tend to rise more slowly than the poverty line.

Second, the government has committed itself to increasing the per-child element of the child tax credit in line with average earnings until April 2007, ${ }^{46}$ but even continuing this policy until April 2010 may not be enough to prevent child poverty from rising. This is because the per-child element of the child tax credit is only one part of the income of low-income households with children. A more successful anti-poverty strategy based on increasing state support in line with earnings would have to apply to all benefits and tax credits received by low-income households with children, including the credits and thresholds of the working tax credit and the level of income support received by parents. Even this might only maintain the current level of child poverty; achieving further reductions in child poverty is likely to require increases above that.

This suggests that unless new and existing policies radically shift work patterns among families with children, ${ }^{47}$ reducing child poverty by 1 million between 2004/05 and 2010/11 to meet the target is likely to require significant new spending measures, at least in the order of past new spending measures. Despite this, social security expenditure is currently set to rise

\footnotetext{
${ }^{46}$ HM Treasury, 2003.

${ }^{47}$ As we showed in Section 4.1, although changes in parental working patterns have led to reductions in child poverty between 1998/99 and 2004/05, without the increases in state benefits for families with children seen in recent years, child poverty would not have fallen by anywhere near as much as it has done. This was demonstrated formally by showing that some of the fall in child poverty between 1998/99 and 2004/05 can be attributed to a reduced proportion of children living in workless households. However, this beneficial compositional effect only accounts for about 100,000 of the fall in child poverty between 1998/99 and 2004/05. Most of the fall in child poverty can instead be put down to the reduced incidence of poverty for children in workless families, those with part-time working lone parents and those in couple families with one full-time parent and one non-working parent.
} 
by only 1.3 per cent per annum in real terms between 2004/05 and 2007/08. This compares with a real growth rate of 3.9 per cent per annum between 1998/99 and 2004/05, ${ }^{48}$ which was also a time of falling levels of expenditure on unemployment, when child poverty fell by about 600,000 (using the Modified OECD scale). Therefore, unless the government is to miss its 2010/11 target, it seems realistic to suggest that further spending will need to be found, financed from extra borrowing, increased taxation or a reordering of spending priorities. Our future work will seek to quantify this additional public expenditure requirement.

\subsection{Conclusion}

By 2004/05, child poverty had fallen by 700,000 since 1998/99 (measuring incomes AHC or BHC), and it is now at its lowest level since the late 1980s, but the government fell 100,000 children short of meeting its target for 2004/05 measuring incomes BHC and 400,000 children short measuring incomes AHC.

The main factors contributing to the decline in poverty since 1998/99 are the substantial declines in the proportion of children in workless households and large falls in the risk of poverty for children in workless families, those with part-time working lone parents and those in couple families with one full-time parent and one non-working parent. And child poverty has fallen despite a rise in the proportion of children living in lone-parent families, who are at over twice the risk of poverty that couples with children are (measuring income AHC).

The government can take much credit for this fall in child poverty, both through its decisions to increase substantially the amount of cash transfers made to families with children and through welfare-to-work and other policies that have helped parents in previously workless families to find work and therefore increase their incomes.

Forecasts made two years ago by civil servants and by independent researchers implied that the government was on track to meet its child poverty targets. These forecasts overstated the decline in child poverty since $2001 / 02$ by around $300,000-400,000$. It is too early to say definitively why these forecasts were too optimistic, although forecasts of child poverty in particular are extremely sensitive to sampling and modelling error, because, for example, 800,000 children were living in households within 5 per cent of the poverty line in 2004/05.

Another contributing factor could be that the survey used to estimate child poverty - the Family Resources Survey - is recording a decreasing proportion of government spending on tax credits at a time when tax credits have become the government's main instrument for reducing child poverty; this may mean that HBAI is increasingly overstating the true level of child poverty. The government should review the ability of the FRS to record accurately families' income from tax credits, given that the government will be using the FRS to track progress towards its future targets for child poverty.

As a result of missing this year's target by 100,000 (measured BHC) and of changes to the way child poverty will be measured for the 2010/11 target to reduce child poverty to half the

\footnotetext{
${ }^{48}$ Figures refer to spending on both social security benefits and tax credits. Growth in real social security and tax credit spending is calculated by deflating spending by growth in the GDP deflator. Sources: period from 1999/2000 to 2003/04 from HM Treasury (2005a); period from 2004/05 onwards from HM Treasury (2005d, table B17); for figures prior to $1999 / 2000$, we assume that the growth in spending on social security benefits and tax credits is the same as the growth in spending on 'social protection' in HM Treasury (2005c).
} 
level of 1998/99, child poverty now has to fall by about 1 million between 2004/05 and 2010/11. This represents a fall over one-and-a-half times greater than the 600,000 fall between 1998/99 and 2004/05 (using the Modified OECD equivalence scale). This will need to be achieved with a lower planned growth rate in social security expenditure. We therefore feel that unless the government is to fall short of this target, or there are radical shifts in parental working patterns, new spending will be needed, from extra borrowing, increased taxation or a reordering of spending priorities. 


\section{Conclusion}

This Commentary has analysed what the latest set of Households Below Average Income (HBAI) statistics tell us about changes in living standards and relative income poverty in Britain up to the year 2004/05. We have considered what the extra year of statistics tell us about living standards and poverty relative to one year before, and have also considered the record over the whole period of the Labour government since 1996/97.

Over the period of the Labour government as a whole, we have shown that living standards have risen: mean incomes rose by 2.4 per cent in real terms each year on average between 1996/97 and 2004/05, with average annual median income growth at 2.2 per cent. This sustained growth in average living standards is somewhat higher than the average annual growth in living standards that took place over the period of the Conservative government between 1979 and 1996/97 as a whole, when mean income growth averaged 2.1 per cent per year and median income growth averaged 1.6 per cent real-terms increase per year. This also suggests a more balanced pattern of income growth under Labour, a point to which we return below.

The relatively strong income growth over the Labour period as a whole masks the fact that the average annual growth in mean and median incomes since 2002/03 has been considerably lower than between 1996/97 and 2002/03. Though we cannot rule out that this apparent slowing could be due to sampling error, it appears that growth of average living standards has slowed in recent years.

The new HBAI statistics also allow us to chart the evolution of income inequality. We have shown that the latest year's data suggest no change in the Gini coefficient. This means that whilst income inequality rose in three out of the first four years of Labour's period in office, it has fallen for three out of the four subsequent years. The net effect is to leave overall levels of inequality effectively unchanged since 1996/97. However, one's conclusion about what has happened to income inequality is sensitive to how one chooses to measure it: the 90/10 ratio, which does not consider the incomes of the very richest or poorest in society, has fallen slightly since 1996/97, highlighting an equalising in the income distribution amongst the majority of the population.

It is not clear whether inequality will continue on a downward path in the future or whether it will continue to fluctuate around what is still a historically high level. What happens to overall levels of inequality in years to come depends to a large extent on what further progress is made in reducing child and pensioner poverty. It will also depend on what happens to top incomes, which we have shown to be a clear driver of inequality change in recent years.

Pensioner poverty has continued to fall rapidly. Whilst there were 2.8 million pensioners who were poor on the 60 per cent median after-housing-costs (AHC) measure in 1996/97, this number had dropped to 1.8 million by $2004 / 05$, a fall of over a third. As was the case in 2003/04, a pensioner chosen at random is less likely to be poor than a non-pensioner, measuring income AHC. Measuring incomes before housing costs (BHC), pensioner poverty 
has also fallen considerably - by almost 10 per cent - since 2003/04, but the decline since Labour came to power is much slower than on the AHC measure.

We have shown that the fall in pensioner poverty is due in part to the changing composition of the pensioner population, as newer (generally richer) cohorts reach retirement age and older ones die out. However, around three-quarters of the fall in pensioner poverty is due to falling poverty within cohorts, suggesting that individual pensioners have become better off, through government policies such as the increased generosity of the pensioner credit compared with its predecessors, and other age-related payments.

Whilst pensioner poverty on the 60 per cent of median AHC measure has fallen by more than a third since 1998/99, child poverty has fallen by rather less, and the government has missed its target to reduce child poverty by a quarter between 1998/99 and 2004/05. Rounding to the nearest 100,000, the target has been missed by 100,000 children on the BHC measure and by 400,000 on the AHC measure. Compared with the aim of reducing child poverty by a quarter, it has fallen by only 21 per cent and 17 per cent respectively in reality.

The fact that the 2004/05 target has been missed should not detract from the fact that the drop in child poverty has been very substantial: by $2004 / 05$, child poverty had fallen by 700,000 since 1998/99 (measuring incomes AHC or BHC), and it is now at its lowest level since the late 1980s. This fall has come despite significant growth in median income (and thus the poverty line) and despite a rise in the proportion of children living in lone-parent families, who are at over twice the risk of poverty that couples with children are. We have shown that the main factors contributing to the decline in poverty since 1998/99 are the substantial declines in the proportion of children in workless households and large falls in the risk of poverty for children in workless families, those with part-time working lone parents and those in couple families with one full-time parent and one non-working parent. The government can take considerable credit for this: the reduction in the risk of poverty amongst these groups is due at least in part to new spending directed towards families, through tax credits. The reduction in the number of children in workless families is also due, at least in part, to government policies that have helped previously non-working parents (particularly lone parents) move into work.

It will also be important for the policy and research community to understand why the 2004/05 target was indeed missed, given that the central estimates of independent commentators such as ourselves (and others) suggested that the tax credit amounts set by the government two years ago should have lifted family incomes by enough to ensure that the target would be met. Although it is too soon to draw definitive conclusions, forecasts of child poverty are extremely sensitive to sampling and modelling error because 800,000 children were living in households within 5 per cent of the poverty line in 2004/05. However, it does appear that an increasing proportion of the money paid out by HM Revenue \& Customs in tax credits is not being recorded by the Family Resources Survey, on which the estimates of poverty are based. Although this issue also needs further investigation, it could mean that HBAI is increasingly overstating the true level of child poverty.

Regardless of the reason why the 2004/05 target was missed, the fact that child poverty had not fallen by a quarter by 2004/05 will make it all the more challenging to ensure that it is reduced by a half by 2010/11. Taking into account the slight change in the way the government is defining poverty for its 2010/11 target, child poverty now has to fall by 
1 million between 2004/05 and 2010/11 in order to meet that target - a fall 50 per cent more than the 600,000 fall achieved between 1998/99 and 2004/05. Unless the government is to downgrade the importance of meeting its 2010/11 target - which seems even less likely for a government where Gordon Brown is Prime Minister than it does for one under Tony Blair - it is uncontroversial to suggest that money will need to be found for substantial further increases in spending on tax credits and other benefits, from extra borrowing, increased taxation or a reordering of spending priorities. Future work funded by the Joseph Rowntree Foundation will seek to quantify this additional public expenditure requirement. 


\section{Appendix A}

\section{The implications of the switch to Modified OECD equivalence scales}

From 2005/06, the HBAI statistics will be presented on a new basis, using Modified OECD equivalence scales instead of the McClements scales. This appendix sets out the scales and presents figures that show how the methodological change will affect the measurement of average income, inequality and poverty. Note that alongside the change in equivalence scales, a minor definitional change to the measure of income will also be introduced. The new series shown here (labelled as 'Modified OECD') also contains this minor definitional change.

Note also that whilst the BHC Modified OECD scale is an internationally recognised scale, the AHC scale has been devised by the Department for Work and Pensions in order to be able to continue to present the new figures on both an $\mathrm{AHC}$ and a $\mathrm{BHC}$ basis.

Table A.1. The McClements and Modified OECD equivalence scales compared

\begin{tabular}{l|cc|cc}
\hline & \multicolumn{2}{|c|}{ BHC income } & \multicolumn{2}{c}{ AHC income } \\
& $\begin{array}{c}\text { Modified OECD } \\
\text { rescaled to } \\
\text { couple without } \\
\text { children =1 }\end{array}$ & $\begin{array}{c}\text { McClements } \\
\text { (couple without } \\
\text { children = 1) }\end{array}$ & $\begin{array}{c}\text { Modified OECD } \\
\text { rescaled to } \\
\text { couple without } \\
\text { children = 1 }\end{array}$ & $\begin{array}{c}\text { McClements } \\
\text { (couple without } \\
\text { children = 1) }\end{array}$ \\
\hline First adult (head) & 0.67 & 0.61 & 0.58 & 0.55 \\
Spouse of head & 0.33 & 0.39 & 0.42 & 0.45 \\
Other second adult & 0.33 & 0.46 & 0.42 & 0.45 \\
Third adult & 0.33 & 0.42 & 0.42 & 0.45 \\
Subsequent adults & 0.33 & 0.36 & 0.42 & 0.40 \\
(each) & & & & \\
& & & & \\
Each dependant & & & & \\
aged: & 0.20 & 0.09 & 0.20 & 0.07 \\
0-1 & 0.20 & 0.18 & 0.20 & 0.18 \\
2-4 & 0.20 & 0.21 & 0.20 & 0.21 \\
$5-7$ & 0.20 & 0.23 & 0.20 & 0.23 \\
8-10 & 0.20 & 0.25 & 0.20 & 0.26 \\
$11-12$ & 0.20 & 0.27 & 0.20 & 0.28 \\
13 & 0.33 & 0.27 & 0.42 & 0.27 \\
$14-15$ & 0.33 & 0.36 & 0.42 & 0.38 \\
$16+$ & & & & \\
\hline
\end{tabular}

Source: Department for Work and Pensions, 2006. 
Figure A.1. Changes in average real income, comparing Modified OECD and McClements equivalence scales

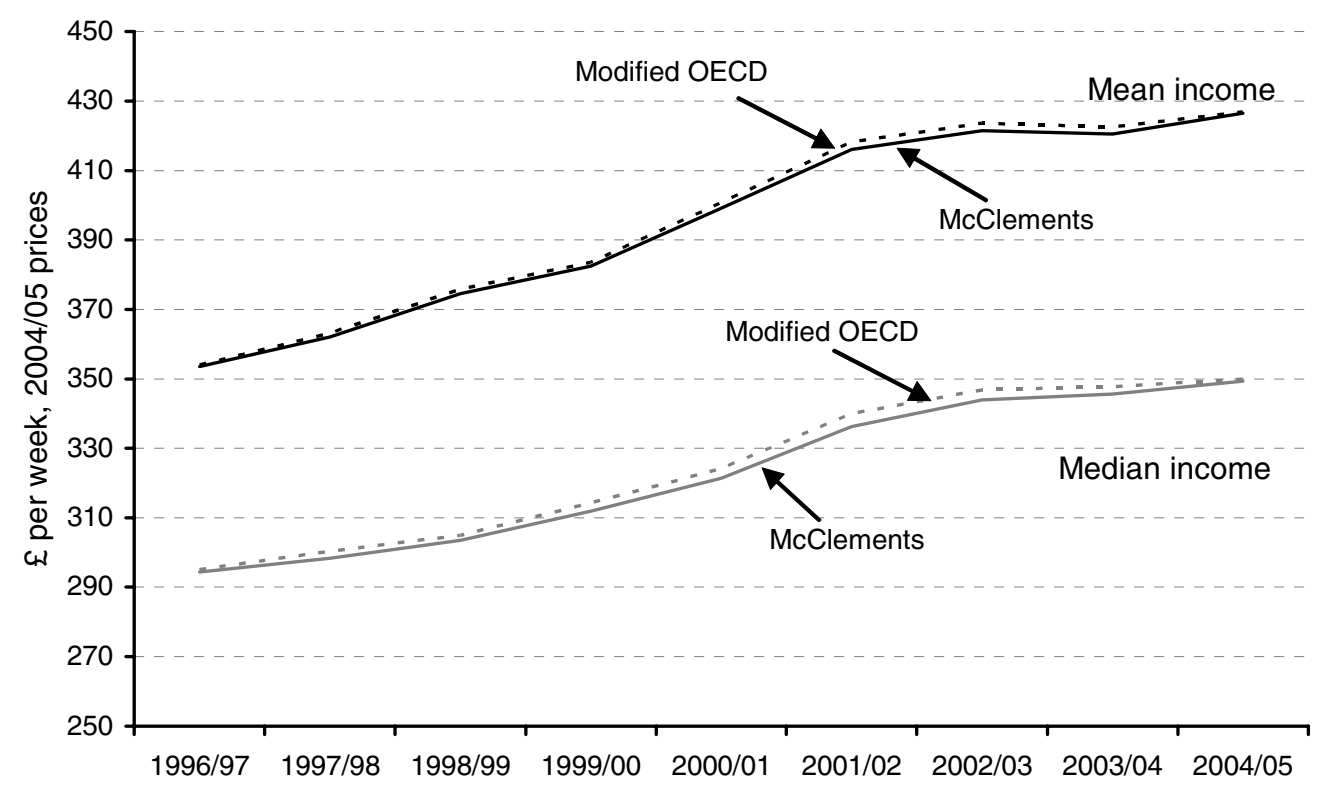

Note: Incomes have been calculated before housing costs have been deducted. Source: Authors' calculations using Family Resources Survey, various years.

Figure A.2. The Gini coefficient for net income since 1979, comparing McClements and Modified OECD equivalence scales

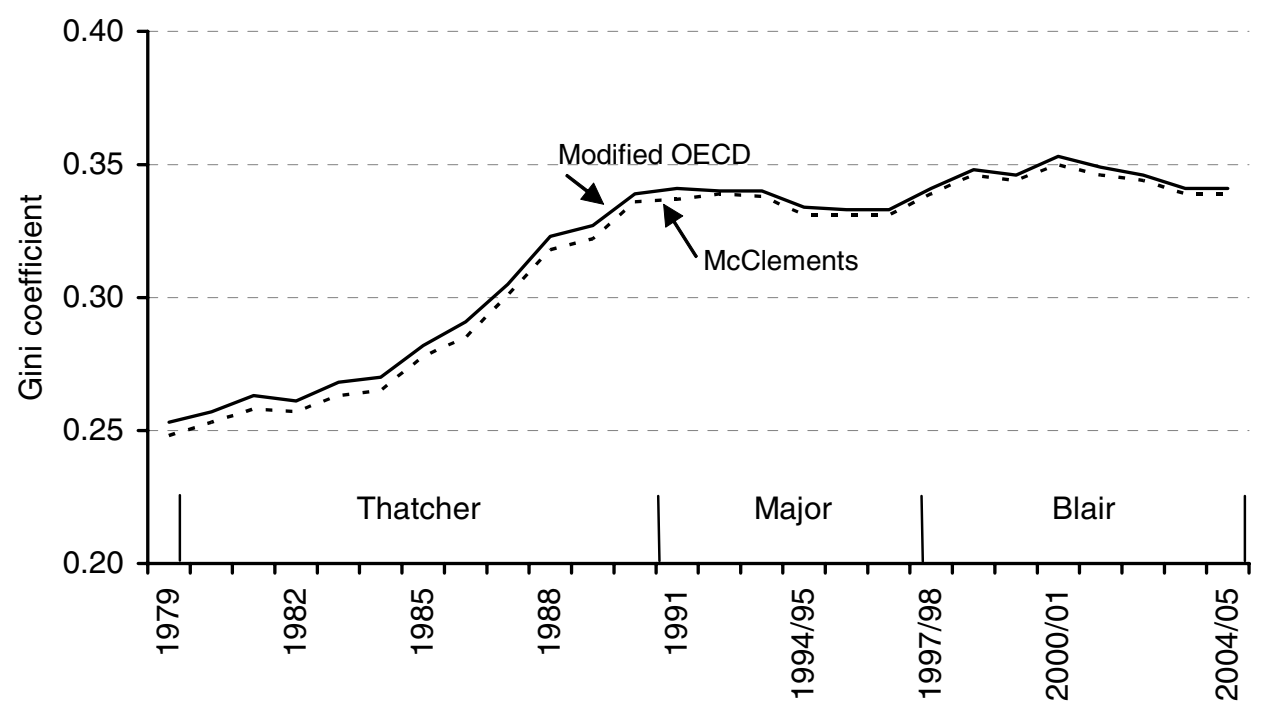

Note: The Gini coefficient has been calculated using incomes before housing costs have been deducted. Source: Authors' calculations using Family Expenditure Survey and Family Resources Survey, various years. 
Table A.2. Relative poverty in Britain: percentage of individuals in households with income below 60 per cent of median income, comparing McClements and Modified OECD equivalence scales

\begin{tabular}{|c|c|c|c|c|c|}
\hline & \multicolumn{4}{|c|}{ Percentage of the population } & \multirow{3}{*}{$\begin{array}{l}\text { Population } \\
\text { (million) }\end{array}$} \\
\hline & \multicolumn{2}{|c|}{$60 \%$ median AHC } & \multicolumn{2}{|c|}{$60 \%$ median BHC } & \\
\hline & McClements & Modified OECD & McClements & Modified OECD & \\
\hline 1996/97 & 24.8 & 25.3 & 18.4 & 19.4 & 55.6 \\
\hline 1997/98 & 23.8 & 24.4 & 18.3 & 19.6 & 55.7 \\
\hline 1998/99 & 23.7 & 24.4 & 18.2 & 19.3 & 55.9 \\
\hline 1999/00 & 23.5 & 24.0 & 17.9 & 19.2 & 56.1 \\
\hline 2000/01 & 22.6 & 23.1 & 17.0 & 18.4 & 56.2 \\
\hline $2001 / 02$ & 21.9 & 22.7 & 16.9 & 18.4 & 56.4 \\
\hline 2002/03 & 21.6 & 22.6 & 17.0 & 18.3 & 56.6 \\
\hline 2003/04 & 21.0 & 21.5 & 16.8 & 17.8 & 56.8 \\
\hline 2004/05 & 19.9 & 20.5 & 16.1 & 17.1 & 57.1 \\
\hline \multicolumn{6}{|l|}{ Change: } \\
\hline Since 1996/97 & -4.9 & -4.7 & -2.3 & -2.4 & \\
\hline Since 1998/99 & -3.7 & -3.9 & -2.2 & -2.3 & \\
\hline
\end{tabular}

Notes: Reported changes may not equal the differences between the corresponding percentages due to rounding. All changes are significantly different from zero at the 5 per cent level.

Sources: Authors' calculations based on Family Resources Survey, various years. Population totals are from the HBAI data-set.

Table A.3. Relative child poverty: number of children living in households with income below 60 per cent of median income, comparing McClements and Modified OECD equivalence scales

\begin{tabular}{l|cc|cc|c}
\hline & \multicolumn{4}{|c|}{ Number of children (million) } & Child \\
& \multicolumn{6}{|c|}{$\mathbf{6 0 \%}$ median AHC } & \multicolumn{2}{c}{$\begin{array}{c}\text { 60\% median BHC } \\
\text { population } \\
\text { (million) }\end{array}$} \\
\hline $1998 / 99$ & 4.1 & 4.3 & 3.1 & 3.3 & 12.7 \\
$1999 / 00$ & 4.1 & 4.2 & 3.0 & 3.3 & 12.7 \\
$2000 / 01$ & 3.8 & 3.9 & 2.7 & 3.0 & 12.7 \\
$2001 / 02$ & 3.7 & 3.9 & 2.6 & 2.9 & 12.6 \\
$2002 / 03$ & 3.6 & 3.8 & 2.6 & 2.9 & 12.6 \\
$2003 / 04$ & 3.5 & 3.6 & 2.6 & 2.8 & 12.5 \\
$2004 / 05$ & 3.4 & 3.6 & 2.4 & 2.7 & 12.6 \\
Change: & & & & & \\
Since 1998/99 & -0.7 & -0.7 & -0.7 & -0.6 & \\
\hline
\end{tabular}

Notes: Reported changes may not equal the differences between the corresponding numbers due to rounding. All changes are significantly different from zero at the 5 per cent level.

Sources: Authors' calculations based on Family Resources Survey, various years. Population totals are from the HBAI data-set. 


\section{Appendix B \\ Supplementary tables for Chapter 2}

In Table B.1, we show the monthly income levels of different family types falling into each income decile group. The variation in income thresholds across family types reflects the income equivalisation process (see the discussion in Section 1.1). Incomes in this table are measured before housing costs have been deducted, after subtracting direct taxes (including council tax) and counting the income from all sources of all the members of the household, including state benefits.

Table B.1. Where do you fit in? Monthly net income of three family types

\begin{tabular}{|c|c|c|c|}
\hline & $\begin{array}{l}\text { Single person, } \\
\text { no children }\end{array}$ & $\begin{array}{l}\text { Couple, } \\
\text { no children }\end{array}$ & $\begin{array}{c}\text { Couple } \\
\text { with two children } \\
\text { aged } 4 \text { and } 13\end{array}$ \\
\hline Bottom decile & $£ 0$ to $£ 500$ & $£ 0$ to $£ 750$ & $£ 0$ to $£ 1,150$ \\
\hline Decile 2 & $£ 500$ to $£ 600$ & $£ 750$ to $£ 950$ & $£ 1,150$ to $£ 1,450$ \\
\hline Decile 3 & $£ 600$ to $£ 700$ & $£ 950$ to $£ 1,150$ & $£ 1,450$ to $£ 1,700$ \\
\hline Decile 4 & $£ 700$ to $£ 800$ & $£ 1,150$ to $£ 1,350$ & $£ 1,700$ to $£ 1,950$ \\
\hline Decile 5 & $£ 800$ to $£ 900$ & $£ 1,350$ to $£ 1,500$ & $£ 1,950$ to $£ 2,200$ \\
\hline Decile 6 & $£ 900$ to $£ 1,050$ & $£ 1,500$ to $£ 1,750$ & $£ 2,200$ to $£ 2,550$ \\
\hline Decile 7 & $£ 1,050$ to $£ 1,200$ & $£ 1,750$ to $£ 2,000$ & $£ 2,550$ to $£ 2,900$ \\
\hline Decile 8 & $£ 1,200$ to $£ 1,450$ & $£ 2,000$ to $£ 2,400$ & $£ 2,900$ to $£ 3,450$ \\
\hline Decile 9 & $£ 1,450$ to $£ 1,850$ & $£ 2,400$ to $£ 3,050$ & $£ 3,450$ to $£ 4,450$ \\
\hline Top decile & $£ 1,850+$ & $£ 3,050+$ & $£ 4,450+$ \\
\hline
\end{tabular}

Note: Incomes have been measured before housing costs have been deducted.

Source: Authors' calculations using Family Resources Survey, 2004/05.

Table B.2 shows how annualised average income growth rates vary by family type between 1996/97 and 2004/05, when incomes are measured AHC. The pattern is essentially the same as when we use a BHC measure, with lone parents and single pensioners experiencing the greatest proportional income gains on average over this period.

Table B.2. Annualised income growth by family type, 1996/97 - 2004/05

\begin{tabular}{l|cc|cc}
\hline & \multicolumn{2}{|c|}{ Mean AHC income } & \multicolumn{2}{c}{ Median AHC income } \\
& Growth & $\mathbf{2 0 0 4 / 0 5}$ level & Growth & 2004/05 level \\
\hline Lone parents & $4.7 \%$ & $£ 228$ & $5.3 \%$ & $£ 193$ \\
Single pensioners & $4.2 \%$ & $£ 319$ & $4.9 \%$ & $£ 263$ \\
Pensioner couples & $3.1 \%$ & $£ 347$ & $3.3 \%$ & $£ 275$ \\
Couples with children & $3.3 \%$ & $£ 363$ & $2.7 \%$ & $£ 294$ \\
Singles without children & $3.2 \%$ & $£ 393$ & $2.5 \%$ & $£ 322$ \\
Couples without children & $2.7 \%$ & $£ 471$ & $2.4 \%$ & $£ 405$ \\
All & & & & \\
\hline
\end{tabular}

Note: Incomes have been measured after housing costs have been deducted. Family types have been ordered in rows by mean $\mathrm{AHC}$ income.

Source: Authors' calculations using Family Resources Survey, various years. 
Table B.3. Real year-on-year growth

\begin{tabular}{l|cccc}
\hline & Mean BHC income & GDP per head & $\begin{array}{c}\text { Household } \\
\text { disposable } \\
\text { income }\end{array}$ & $\begin{array}{c}\text { DWP variant of } \\
\text { households' } \\
\text { disposable income } \\
\text { per head }\end{array}$ \\
\hline $1996 / 97$ & $3.4 \%$ & $2.5 \%$ & $3.3 \%$ & $0.4 \%$ \\
$1997 / 98$ & $2.4 \%$ & $3.0 \%$ & $3.6 \%$ & $3.3 \%$ \\
$1998 / 99$ & $3.4 \%$ & $2.9 \%$ & $3.7 \%$ & $0.7 \%$ \\
$1999 / 00$ & $2.1 \%$ & $3.0 \%$ & $4.5 \%$ & $3.5 \%$ \\
$2000 / 01$ & $4.4 \%$ & $3.2 \%$ & $3.3 \%$ & $3.3 \%$ \\
$2001 / 02$ & $4.2 \%$ & $1.6 \%$ & $3.0 \%$ & $3.6 \%$ \\
$2002 / 03$ & $1.3 \%$ & $1.7 \%$ & $2.7 \%$ & $-0.3 \%$ \\
$2003 / 04$ & $-0.2 \%$ & $2.5 \%$ & $2.5 \%$ & $0.8 \%$ \\
$2004 / 05$ & $1.4 \%$ & $2.7 \%$ & $3.5 \%$ & $2.1 \%$ \\
\hline
\end{tabular}

Sources: Authors' calculations using Family Resources Survey and Office for National Statistics (2005b and earlier years); DWP has created the "variant of households' disposable income per head" for validation purposes.

Comparisons over short periods may be unreliable. Figures used courtesy of DWP.

Table B.3 shows the changes in average living standards using the HBAI methodology compared with other national statistics relating to income growth. Note that since these each measure different concepts of income and cover different populations, we would not necessarily expect them to show the same trends. The table also shows the growth in a measure of households' real disposable income contained in the Blue Book that has been modified to be more comparable to the official HBAI income series; these rates mirror the low income growth seen in the HBAI data in 2002/03 and 2003/04. 


\section{Appendix C}

\section{Summary measures of inequality}

A widely used measure of income inequality is the Gini coefficient. The Gini coefficient benefits from an intuitive geometric interpretation in the form of the Lorenz curve. In Figure C.1, the horizontal axis corresponds to the cumulative percentage of individuals in the population, while the vertical axis gives the cumulative percentage of income. The Lorenz curve then shows the relationship between the percentage of income recipients and the percentage of income actually received. Assume that individuals are placed in ascending order on the basis of their household income, so that the Lorenz curve is below the 45-degree line. Figure C. 1 shows the Lorenz curve drawn using actual data from 2004/05. If income were equally distributed across households, then 10 per cent of the population would have exactly 10 per cent of total income, 20 per cent of the population would have 20 per cent of total income, and so on. The line of perfect equality is therefore given by the 45-degree line, $\mathrm{AB}$. Note that the further is the Lorenz curve from the line of perfect equality, the greater is the degree of inequality.

Figure C.1. The Lorenz curve and Gini coefficient, 2004/05

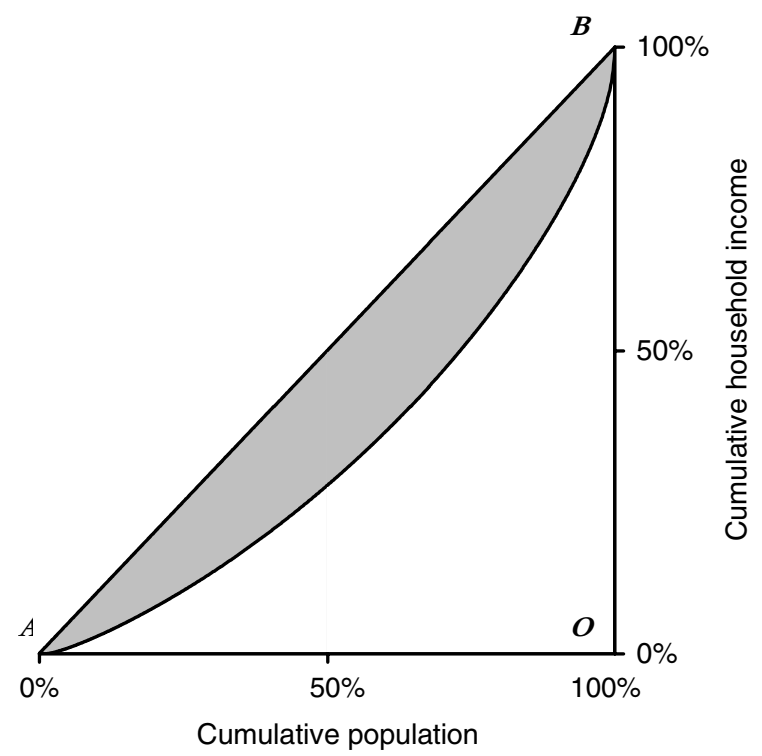

Note: Incomes have been measured before housing costs have been deducted.

Source: Authors' calculations using Family Resources Survey, 2004/05.

The Gini coefficient is obtained by taking the ratio of the shaded area to the area of the triangle $\mathrm{ABO}$. When there is perfect equality, the shaded area will have zero measure so that the Gini coefficient will be 0 . Conversely, when there is complete inequality (a single household having command over the entire income of the economy), the shaded area will coincide with $\mathrm{ABO}$ so that the Gini coefficient will equal 1.

Figure C.2 shows the Atkinson inequality measure (AIM) for three different values of the relative inequality aversion parameter, $\varepsilon: 0.5,1$ and 1.5 . As one would expect, the higher the 
value of $\varepsilon$, the higher is the value of the AIM, for all years. The graph also shows that, whatever the value of $\varepsilon$, inequality would be judged to have risen between 1996/97 and $2001 / 02$ but to have fallen since then, so that in 2004/05 it is slightly higher than it was in 1996/97. Therefore, societies with three very different values of relative inequality aversion would have viewed recent trends in inequality in very similar ways.

Figure C.2. The Atkinson inequality measure, 1996/97 - 2004/05

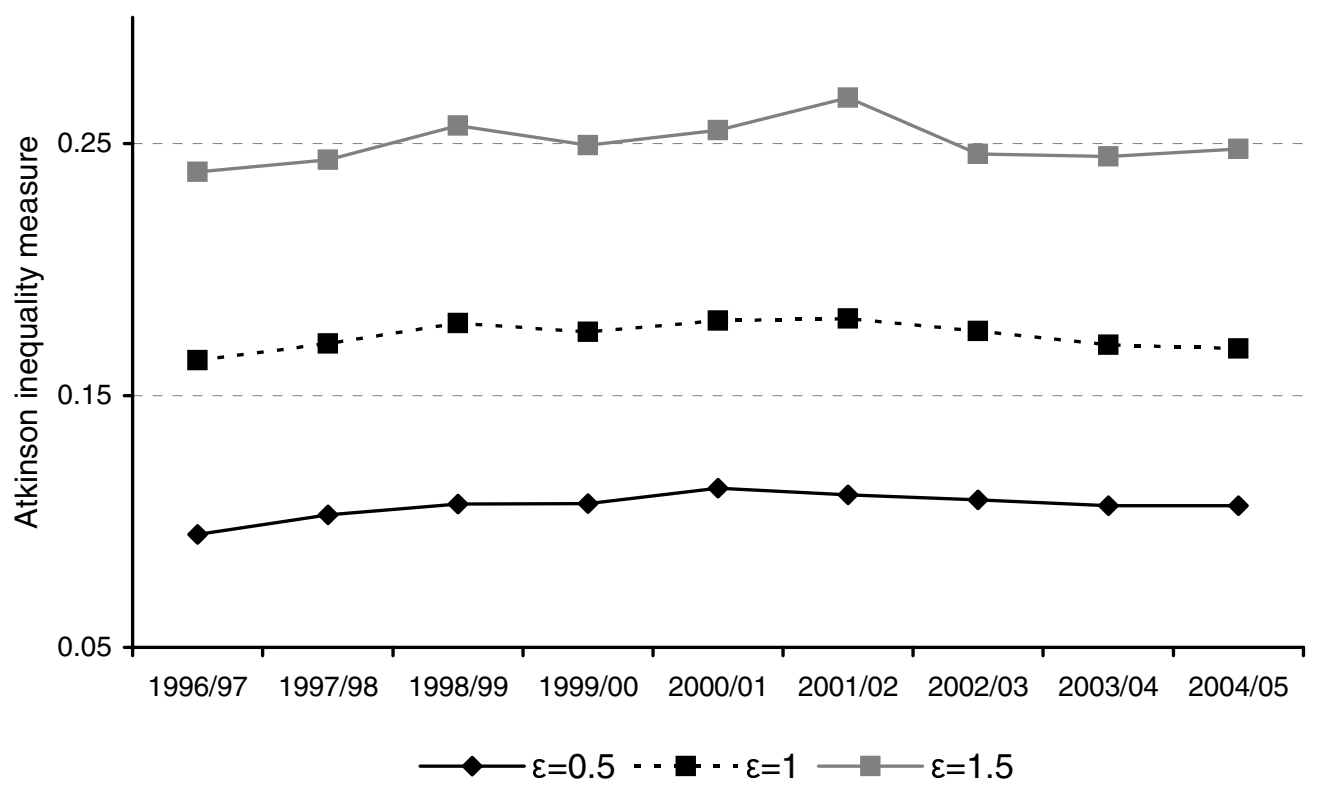

Note: The AIM has been calculated using incomes before housing costs have been deducted.

Source: Authors' calculations using Family Resources Survey, various years. 


\section{Appendix D Decomposition of falls in poverty}

As set out in Sutherland, Sefton and Piachaud (2003), changes in the poverty rate over time can be decomposed into two separate effects: compositional and incidence effects (discussed in detail below together with the formula used to obtain them). This decomposition is referred to in Chapter 3 when decomposing the change in the rate of pensioner poverty since 1996/97.

Changes in the number of individuals in poverty over time can also be decomposed into these two same effects, plus a population effect (discussed below together with the formula used to obtain them). This decomposition is the one performed in Chapter 4 when decomposing the change in the level of child poverty. The reason for using this decomposition is that the government has defined its targets for child poverty in 2004/05 and 2010 to be cutting the number of children in poverty by 25 per cent and 50 per cent since 1998/99, respectively. Therefore, we are interested to know what proportion of the fall in child poverty since $1998 / 99$ is simply due to a change in the population.

\section{The compositional effect}

The compositional effect reflects the fact that the proportion of the overall population of interest (e.g. pensioners or children) made up by specific groups (e.g. cohorts or lone parents) is changing over time. If these groups experience different poverty rates, then the rate of poverty will change over time as the composition of the population changes. For example, if the proportion of children in lone-parent families is increasing over time, all other things being equal, poverty will rise since this group has a higher-than-average child poverty rate. To take another example, if the proportion of the pensioner population made up by cohorts with higher levels of private and public resources increases over time, then pensioner poverty will fall, as this group has a lower-than-average pensioner poverty rate.

\section{The incidence effect}

The incidence effect represents the change in the risk of being in poverty for a specific group, the size of which will depend on the proportion of the group in the overall population. For example, as a result of increased expenditure on in-work benefits, children in working loneparent families might have become less likely to be in poverty over time. Similarly, measures targeted at older pensioners, such as the winter fuel allowance and concessionary TV licences, might reduce the risk of being in poverty for older pensioners.

\section{The population effect}

The population effect is only relevant when decomposing the change in the number of individuals in poverty. It refers to the fact that the overall population of interest may be changing over time. Even if the likelihood of being in poverty for specific groups remains unchanged and there are no compositional changes, the poverty level will change over time simply as the population varies. To take an example, there are now fewer children and so, all else being equal, fewer children in poverty. 
Formula for the decomposition of the change in the poverty rate

$$
X_{\text {overall }, t+1}-X_{\text {overall }, t} \approx \sum_{i}\left(p_{i, t+1}-p_{i, t}\right)\left(\frac{X_{i, t}-X_{\text {overal }, t}+X_{i, t+1}-X_{\text {overall }, t+1}}{2}\right)+\sum_{i}\left(\frac{p_{i, t}+p_{i, t+1}}{2}\right)\left(X_{i, t+1}-X_{i, t}\right)
$$

Total Effect $\approx \quad$ Compositional Effect $\quad+\quad$ Incidence Effect

Formula for the decomposition of the change in the number of individuals in poverty

$$
\begin{gathered}
X_{\text {overall },+1} N_{t+1}-X_{\text {overall }, t} N_{t} \approx \sum_{i}\left(p_{i, t+1}-p_{i, t}\right)\left(\frac{X_{i, t}-X_{\text {overall }, t}+X_{i, t+1}-X_{\text {overall }, t+1}}{2}\right) \bar{N}+\sum_{i}\left(\frac{p_{i, t}+p_{i, t+1}}{2}\right)\left(X_{i, t+1}-X_{i, t}\right) \bar{N} \\
+\left(\frac{X_{\text {overall }, t+1}+X_{\text {overall }, t}}{2}\right)\left(N_{t+1}-N_{t}\right)
\end{gathered}
$$

Total Effect $\quad \approx \quad$ Compositional Effect $\quad+\quad$ Incidence Effect

$$
+\quad \text { Population Effect }
$$

where

$X_{i, t} \quad$ poverty rate amongst group $i$ at time $t$;

$X_{\text {overall,t }} \quad$ overall poverty rate at time $t$;

$p_{i, t} \quad$ proportion of the population made up by group $i$ at time $t$;

$N_{t} \quad$ population at time $t$;

$\bar{N} \quad$ mean population over the periods in question. 


\section{Appendix E Supplementary tables for Chapter 4}

Chapter 4 presented a number of decompositions of child poverty. All of these were based on incomes measured AHC. This appendix contains the same decompositions but using BHC incomes (see Appendix D for more information about the decomposition). We also include the AHC decomposition for 2001/02 to 2004/05, referred to in Section 4.2.

Table E.1. Decomposition of change in relative child poverty $(\mathrm{BHC})$, 1998/99 - 2004/05

\begin{tabular}{|c|c|c|c|c|c|c|c|}
\hline & \multicolumn{2}{|c|}{$\begin{array}{l}\text { Percentage of } \\
\text { child population }\end{array}$} & \multicolumn{2}{|c|}{ Poverty rate (\%) } & \multirow[t]{2}{*}{$\begin{array}{c}\text { Compositional } \\
\text { effect }\end{array}$} & \multirow[t]{2}{*}{$\begin{array}{c}\text { Incidence } \\
\text { effect }\end{array}$} & \multirow{2}{*}{$\begin{array}{c}\text { Total } \\
\text { change in } \\
\text { poverty }\end{array}$} \\
\hline & $1998 / 99$ & $2004 / 05$ & $1998 / 99$ & $2004 / 05$ & & & \\
\hline $\begin{array}{l}\text { Children in lone- } \\
\text { parent families }\end{array}$ & 22.8 & 24.5 & 39.2 & 30.7 & 26,945 & $-254,186$ & $-227,241$ \\
\hline $\begin{array}{l}\text { Children in } \\
\text { couple families }\end{array}$ & 77.2 & 75.5 & 20.1 & 15.8 & 8,306 & $-411,014$ & $-402,708$ \\
\hline \multirow[t]{2}{*}{ All children } & 100.0 & 100.0 & 24.5 & 19.5 & 35,251 & $-665,200$ & $-629,950$ \\
\hline & \multicolumn{2}{|c|}{ Total } & & & & & \\
\hline $\begin{array}{l}\text { Population effect } \\
\text { All changes }\end{array}$ & \multicolumn{2}{|c|}{$12,692,811 \quad 12,552,021$} & & & & & $\begin{array}{l}-30,915 \\
-660,865\end{array}$ \\
\hline
\end{tabular}

Notes: The table reports unrounded numbers to illustrate the exact nature of the decomposition, but some of the effects are small and may give a spurious impression of accuracy regarding the actual changes in child poverty that have taken place. Rows and columns may not sum exactly to totals due to rounding.

Source: Authors' calculations from various HBAI data-sets. 
Table E.2. Decomposition of change in relative child poverty (BHC), $1998 / 99-2004 / 05$

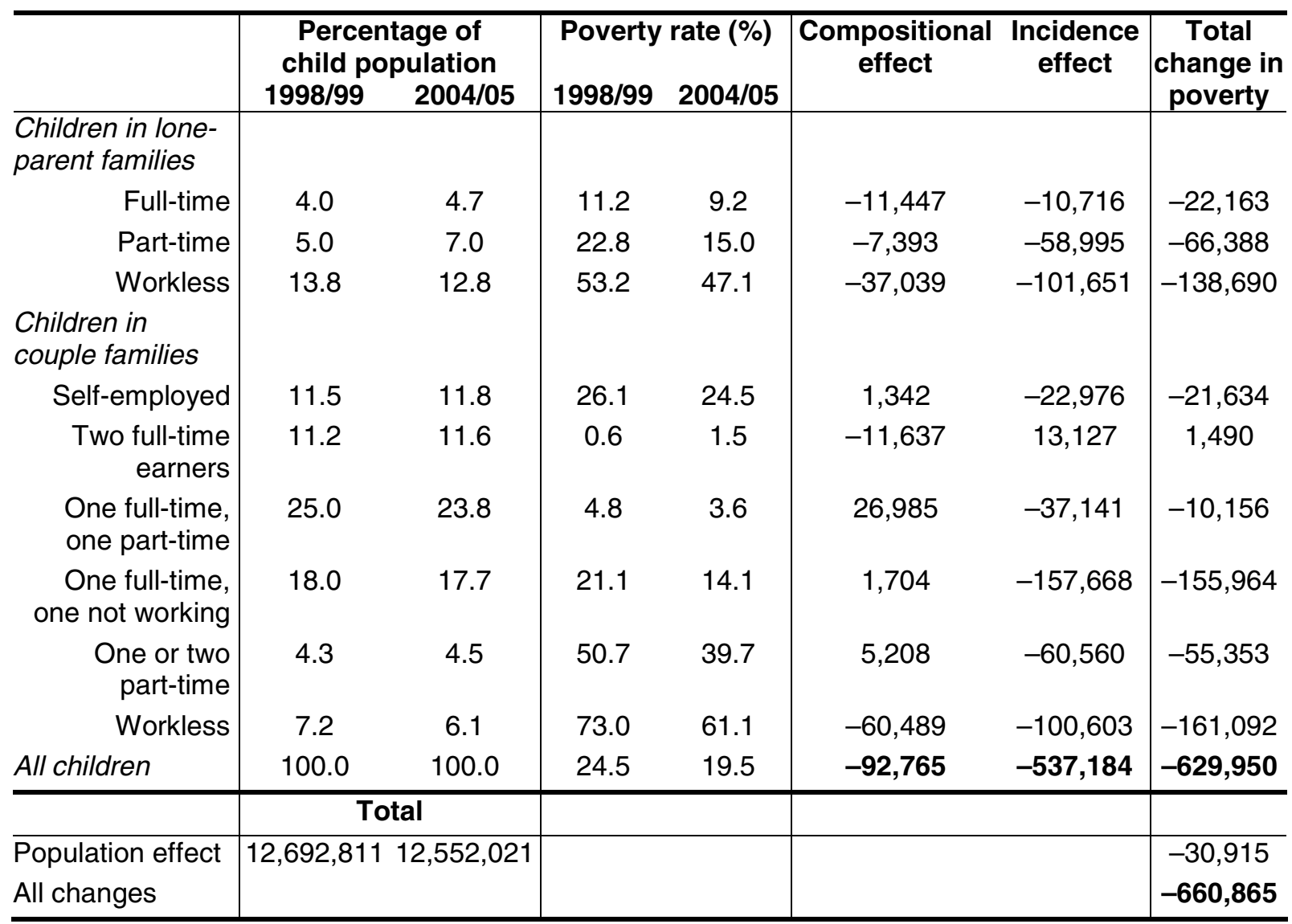

Notes: The table reports unrounded numbers to illustrate the exact nature of the decomposition, but some of the effects are small and may give a spurious impression of accuracy regarding the actual changes in child poverty that have taken place. Rows and columns may not sum exactly to totals due to rounding.

Source: Authors' calculations from various HBAl datasets. 
Table E.3. Decomposition of change in relative child poverty $(\mathrm{BHC})$, 2001/02 - 2004/05

\begin{tabular}{|c|c|c|c|c|c|c|c|}
\hline & \multicolumn{2}{|c|}{$\begin{array}{c}\text { Percentage of } \\
\text { child population }\end{array}$} & \multicolumn{2}{|c|}{ Poverty rate (\%) } & \multirow{2}{*}{$\begin{array}{c}\text { Compositional } \\
\text { effect }\end{array}$} & \multirow{2}{*}{$\begin{array}{c}\text { Incidence } \\
\text { effect }\end{array}$} & \multirow{2}{*}{$\begin{array}{c}\text { Total } \\
\text { change in } \\
\text { poverty }\end{array}$} \\
\hline & 2001/02 & 2004/05 & $2001 / 02$ & $2004 / 05$ & & & \\
\hline \multicolumn{8}{|l|}{$\begin{array}{l}\text { Children in lone- } \\
\text { parent families }\end{array}$} \\
\hline Full-time & 4.8 & 4.7 & 8.1 & 09.2 & 1,580 & 6,458 & 8,038 \\
\hline Part-time & 6.0 & 7.0 & 22.2 & 15.0 & -616 & $-58,788$ & $-59,404$ \\
\hline Workless & 13.7 & 12.8 & 45.3 & 47.1 & $-30,079$ & 29,965 & -114 \\
\hline \multicolumn{8}{|l|}{$\begin{array}{l}\text { Children in } \\
\text { couple families }\end{array}$} \\
\hline Self-employed & 11.6 & 11.8 & 30.5 & 28.6 & 935 & 15,121 & 16,056 \\
\hline Two full-time earners & 12.7 & 11.6 & 1.1 & 2.1 & 25,499 & 10,689 & 36,188 \\
\hline $\begin{array}{l}\text { One full-time } \\
\text { one part-time }\end{array}$ & 23.3 & 23.8 & 6.7 & 6.5 & $-10,489$ & $-28,420$ & $-38,909$ \\
\hline $\begin{array}{r}\text { One full-time, } \\
\text { one not working }\end{array}$ & 17.7 & 17.7 & 27.8 & 21.0 & 88 & $-20,437$ & $-20,349$ \\
\hline One or two part-time & 4.2 & 4.5 & 57.4 & 48.6 & 8,053 & $-70,120$ & $-62,067$ \\
\hline Workless & 6.0 & 6.1 & 82.2 & 71.7 & 9,719 & $-49,340$ & $-39,621$ \\
\hline \multirow[t]{2}{*}{ All children } & 100.0 & 100.0 & 20.7 & 19.5 & 4,690 & $-164,872$ & $-160,182$ \\
\hline & \multicolumn{2}{|c|}{ Total } & & & & & \\
\hline $\begin{array}{l}\text { Population effect } \\
\text { All changes }\end{array}$ & \multicolumn{2}{|c|}{$12,620,436 \quad 12,552,021$} & & & & & $\begin{array}{l}-13,753 \\
-173,935\end{array}$ \\
\hline
\end{tabular}

Notes: The table reports unrounded numbers to illustrate the exact nature of the decomposition, but some of the effects are small and may give a spurious impression of accuracy regarding the actual changes in child poverty that have taken place. Rows and columns may not sum exactly to totals due to rounding.

Source: Authors' calculations from various HBAl data-sets.

Table E.4. Actual and forecast incidence effects for the change in child poverty (BHC), 2001/02 - 2004/05

\begin{tabular}{r|ccc}
\hline & Predicted & Actual & Difference \\
\hline Children in lone-parent families & & & \\
Full-time & $-7,485$ & 6,458 & 13,943 \\
Part-time & $-49,086$ & $-58,788$ & $-9,702$ \\
Workless & $-263,676$ & 29,965 & 293,641 \\
Children in couple families & & & \\
Self-employed & $-53,809$ & 15,121 & 68,930 \\
Two full-time earners & -837 & 10,689 & 11,526 \\
One full-time, one part-time & $-25,675$ & $-28,420$ & $-2,745$ \\
One full-time, one not working & $-68,176$ & $-20,437$ & 47,739 \\
One or two part-time & $-45,139$ & $-70,120$ & $-24,981$ \\
Workless & $-105,765$ & $-49,340$ & 56,425 \\
\hline & $-619,647$ & $-164,872$ & 454,775
\end{tabular}

Notes: The table reports unrounded numbers to illustrate the exact nature of the decomposition, but some of the effects are small and may give a spurious impression of accuracy regarding the actual changes in child poverty that have taken place. Rows and columns may not sum exactly to totals due to rounding.

Source: Authors' calculations from various HBAI data-sets and own calculations based on TAXBEN. A positive 'difference' means that child poverty fell by less than expected (or rose by more than expected). The predicted incidence effects have been calculated as the predicted change in child poverty for children in the nine family types multiplied by the number of children in each group in 2001/02. This table uses data from Brewer (2004). 
Table E.5. Decomposition of change in relative child poverty (AHC), $2001 / 02-2004 / 05$

\begin{tabular}{|c|c|c|c|c|c|c|c|}
\hline & \multicolumn{2}{|c|}{$\begin{array}{l}\text { Percentage of } \\
\text { child population }\end{array}$} & \multicolumn{2}{|c|}{ Poverty rate (\%) } & \multirow{2}{*}{$\begin{array}{c}\text { Compositional } \\
\text { effect }\end{array}$} & \multirow{2}{*}{$\begin{array}{c}\text { Incidence } \\
\text { effect }\end{array}$} & \multirow{2}{*}{$\begin{array}{c}\text { Total } \\
\text { change in } \\
\text { poverty }\end{array}$} \\
\hline & $2001 / 02$ & $2004 / 05$ & $2001 / 02$ & $2004 / 05$ & & & \\
\hline \multicolumn{8}{|l|}{$\begin{array}{l}\text { Children in lone- } \\
\text { parent families }\end{array}$} \\
\hline Full-time & 4.8 & 4.7 & 11.8 & 13.0 & 2,213 & 7,538 & 9,751 \\
\hline Part-time & 6.0 & 7.0 & 39.1 & 27.4 & 1,995 & $-96,054$ & $-94,059$ \\
\hline Workless & 13.7 & 12.8 & 75.7 & 72.3 & $-52,533$ & $-57,455$ & $-109,988$ \\
\hline \multicolumn{8}{|l|}{$\begin{array}{l}\text { Children in } \\
\text { couple families }\end{array}$} \\
\hline Self-employed & 11.6 & 11.8 & 27.7 & 28.6 & -50 & 13,207 & 13,157 \\
\hline $\begin{array}{r}\text { Two full-time } \\
\text { earners }\end{array}$ & 12.7 & 11.6 & 1.4 & 2.1 & 35,848 & 11,287 & 47,135 \\
\hline $\begin{array}{l}\text { One full-time, } \\
\text { one part-time }\end{array}$ & 23.3 & 23.8 & 7.0 & 6.5 & $-14,211$ & $-15,996$ & $-30,207$ \\
\hline $\begin{array}{l}\text { One full-time, } \\
\text { one not working }\end{array}$ & 17.7 & 17.7 & 21.9 & 21.0 & 111 & $-20,400$ & $-20,289$ \\
\hline $\begin{array}{r}\text { One or two } \\
\text { part-time }\end{array}$ & 4.2 & 4.5 & 58.8 & 48.6 & 7,828 & $-56,216$ & $-48,388$ \\
\hline Workless & 6.0 & 6.1 & 82.0 & 71.7 & 10,654 & $-79,007$ & $-68,354$ \\
\hline \multirow[t]{2}{*}{ All children } & 100.0 & 100.0 & 29.6 & 27.2 & $-8,144$ & $-293,097$ & $-301,241$ \\
\hline & \multicolumn{2}{|c|}{ Total } & & & & & \\
\hline $\begin{array}{l}\text { Population effect } \\
\text { All changes }\end{array}$ & $12,620,436$ & $12,552,021$ & & & & & $\begin{array}{l}-19,430 \\
-\mathbf{3 2 0 , 6 7 1}\end{array}$ \\
\hline
\end{tabular}

Notes: The table reports unrounded numbers to illustrate the exact nature of the decomposition, but some of the effects are small and may give a spurious impression of accuracy regarding the actual changes in child poverty that have taken place. Rows and columns may not sum exactly to totals due to rounding.

Source: Authors' calculations from various HBAI data-sets. 


\section{Appendix F Children in workless families}

Table F.1 sets out what has happened to work patterns among families with children since 1996/97 in the HBAI data-set. It shows that worklessness fell sharply between 1996/97 and 2002/03, but rose between 2002/03 and 2003/04. After the 2003/04 data were released, IFS researchers estimated that a return to 2002/03 levels of worklessness by 2004/05 would reduce poverty by around 80,000 $\mathrm{BHC}$ and 90,000 AHC (Brewer et al., 2005). In fact, worklessness rates in 2004/05 did fall towards the levels seen in 2002/03, but by itself this was clearly insufficient for child poverty to reach its target in 2004/05.

Table F.1. Composition of families to which children belong

\begin{tabular}{|c|c|c|c|c|c|c|c|c|}
\hline & \multicolumn{3}{|c|}{$\begin{array}{l}\text { Children in lone-parent } \\
\text { families }\end{array}$} & \multicolumn{4}{|c|}{ Children in couple families } & \multirow[b]{2}{*}{ 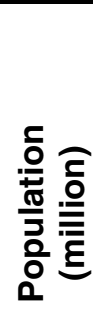 } \\
\hline & 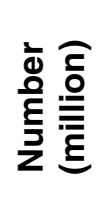 & 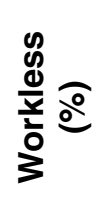 & 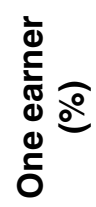 & 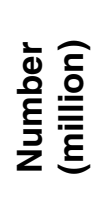 & 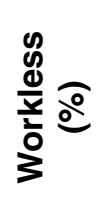 & 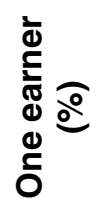 & 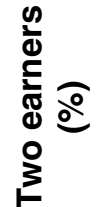 & \\
\hline 1996/97 & 2.7 & 66.5 & 33.5 & 10.0 & 12.0 & 31.8 & 56.2 & 12.7 \\
\hline 1997/98 & 2.8 & 62.5 & 37.5 & 9.9 & 9.8 & 32.1 & 58.1 & 12.7 \\
\hline 1998/99 & 2.9 & 61.1 & 38.9 & 9.8 & 9.6 & 31.2 & 59.1 & 12.7 \\
\hline $1999 / 00$ & 3.1 & 59.5 & 40.5 & 9.6 & 9.0 & 31.2 & 59.8 & 12.7 \\
\hline 2000/01 & 3.1 & 57.6 & 42.4 & 9.6 & 8.4 & 32.3 & 59.3 & 12.7 \\
\hline 2001/02 & 3.1 & 56.1 & 43.9 & 9.5 & 8.1 & 31.7 & 60.2 & 12.6 \\
\hline 2002/03 & 3.1 & 52.0 & 48.0 & 9.5 & 8.1 & 32.6 & 59.3 & 12.6 \\
\hline 2003/04 & 3.1 & 53.2 & 46.8 & 9.5 & 9.0 & 33.8 & 57.2 & 12.5 \\
\hline 2004/05 & 3.1 & 52.8 & 47.2 & 9.5 & 8.3 & 33.0 & 58.6 & 12.6 \\
\hline
\end{tabular}

Sources: Authors' calculations based on the Family Resources Survey, various years. Population totals are from the HBAI data-set.

Overall levels of worklessness changed little between 2001/02 and 2004/05, so this cannot explain why child poverty fell by less than expected. In fact, Tables E.3 and E.5 in Appendix E showed that the reduction in the proportion of children in workless lone-parent families between 2001/02 and 2004/05 - which acted to lower child poverty - was offset almost exactly by a reduction in work effort amongst adults in couple families - which acted to increase child poverty. Table F.1 makes it clear that 2001/02 saw the highest proportion of couples with children having two earners over the period 1996/97 to 2004/05.

In Brewer et al. (2005), IFS researchers observed that the year-on-year rise in worklessness in the FRS was not visible in an equivalent series derived from the Labour Force Survey (although the rise in the FRS was not statistically significant). Figure F.1 repeats the comparison with an extra year of data; it is now clearer that the pattern since 2001 has been one of a very slight decline, and certainly a much slower decline than between 1996 and 2000. 
Figure F.1. Proportion of children aged under 16 living in workless workingage households in the FRS and LFS

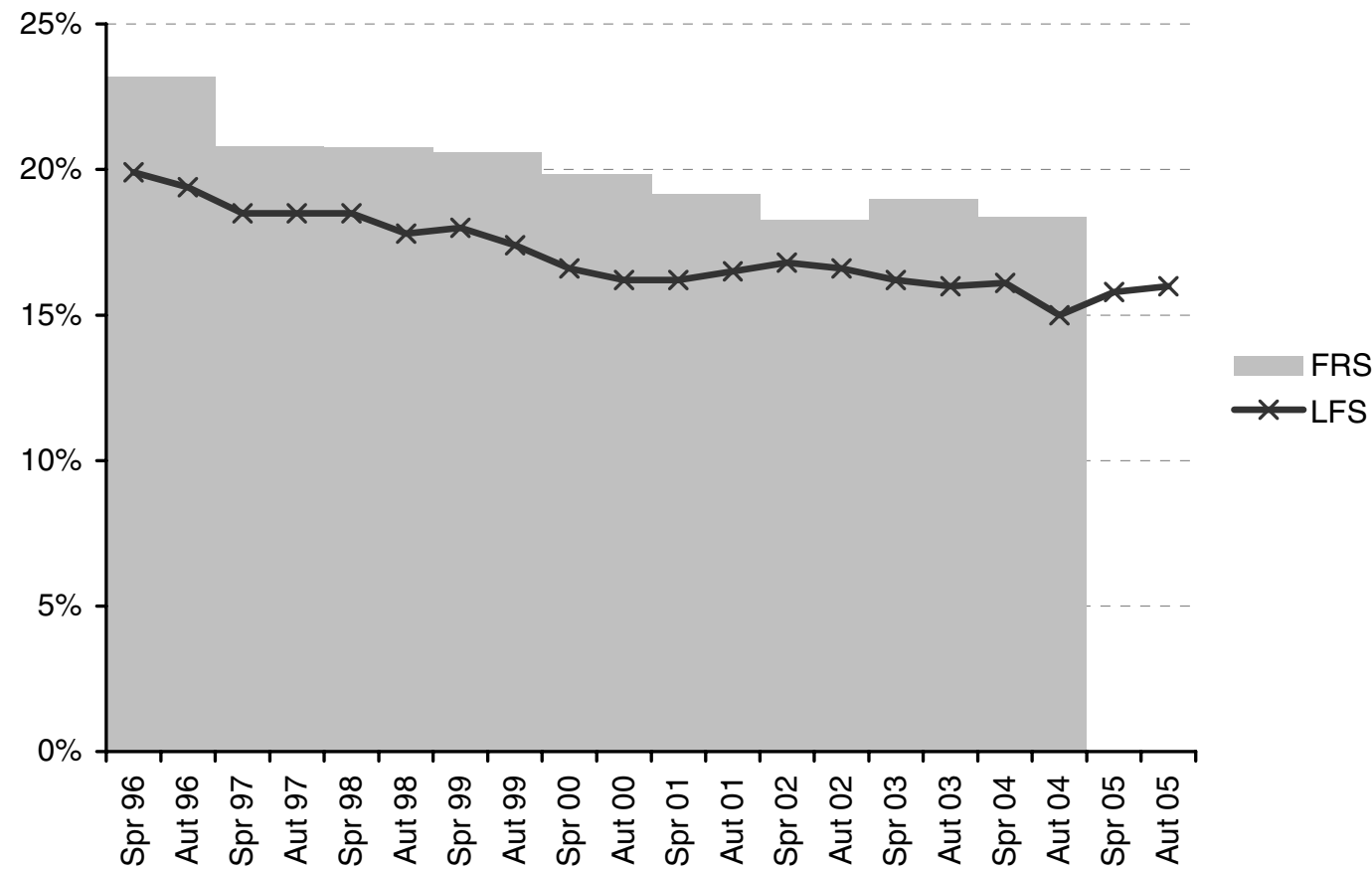

Notes: A household is a collection of individuals living at the same address (potentially more than one family). A working-age household is a household that includes at least one person of working age (16-59 for women, 16-64 for men). A workless household is a household that contains no one aged 16 or over who is in employment. These definitions are slightly different from those used elsewhere in this Commentary.

Sources: Table 3(ii) of Office for National Statistics (2005a and 2006) based on Labour Force Survey data; authors' calculations based on Family Resources Survey, various years. 


\section{References}

Adam, S. and Brewer, M. (2004), Supporting Families: The Financial Costs and Benefits of Children since 1975, Bristol: Policy Press.

Adam, S. and Wakefield, M. (2005), 'The distributional effects of tax and benefit reforms since 1997', in R. Chote, C. Emmerson, D. Miles and Z. Oldfield (eds), The IFS Green Budget: January 2005, Commentary no. 97, London: Institute for Fiscal Studies (www.ifs.org.uk/budgets/gb2005/index.php).

Atkinson, A.B. (1983), The Economics of Inequality, Oxford: Oxford University Press.

Blundell, R. and Preston, I. (1998), 'Consumption inequality and income uncertainty', Quarterly Journal of Economics, vol. 113, pp. 603-40.

Brewer, M. (2003), What Do the Child Poverty Targets Mean for the Child Tax Credit? An Update, Briefing Note no. 41, London: Institute for Fiscal Studies (www.ifs.org.uk/publications.php?publication_id=1789).

Brewer, M. (2004), Will the Government Hit Its Child Poverty Target in 2004-05?, Briefing Note no. 47, London: Institute for Fiscal Studies (www.ifs.org.uk/publications.php?publication_id=1795).

Brewer, M. (2006), 'Tax credits: fixed or beyond repair?', in R. Chote, C. Emmerson, R. Harrison and D. Miles (eds), The IFS Green Budget: January 2006, Commentary no. 100, London: Institute for Fiscal Studies (www.ifs.org.uk/publications.php?publication id=3552).

Brewer, M. and Browne, J. (2006), The Effect of the Working Families' Tax Credit on Labour Market Participation, Briefing Note no. 69, London: Institute for Fiscal Studies (www.ifs.org.uk/bns/bn69.pdf).

Brewer, M., Clark, T. and Goodman, A. (2002), The Government's Child Poverty Target: How Much Progress Has Been Made?, Commentary no. 88, London: Institute for Fiscal Studies (www.ifs.org.uk/publications.php?publication id=1946).

Brewer, M., Clark, T. and Goodman, A. (2003), 'What really happened to child poverty in the UK under Labour's first term?', Economic Journal, vol. 113, pp. F240-57.

Brewer, M., Goodman, A. and Leicester, A. (2006), Household Expenditure: What Can It Teach Us about Poverty in Britain?, Bristol: Policy Press, forthcoming.

Brewer, M., Goodman, A., Myck, M., Shaw, J. and Shephard, A. (2004), Poverty and Inequality in Britain: 2004, Commentary no. 96, London: Institute for Fiscal Studies (www.ifs.org.uk/publications.php?publication_id=1799).

Brewer, M., Goodman, A., Shaw, J. and Shephard, A. (2005), Poverty and Inequality in Britain: 2005, Commentary no. 99, London: Institute for Fiscal Studies (www.ifs.org.uk/publications.php?publication_id=3328).

Brewer, M. and Gregg, P. (2003), 'Eradicating child poverty in Britain: welfare reform and children since 1997', in R. Walker and M. Wiseman (eds), The Welfare We Want? The British Challenge to the American Reform, Bristol: Policy Press. 
Brewer, M. and Shaw, J. (2006), How Many Lone Parents Are Receiving Tax Credits?, Briefing Note no. 70, London: Institute for Fiscal Studies (www.ifs.org.uk/bns/bn70.pdf).

Brewer, M. and Shephard, A. (2004), Has Labour Made Work Pay?, York: Joseph Rowntree Foundation (www.ifs.org.uk/publications.php?publication_id=3155).

Chote, R., Emmerson, C. and Frayne, C. (2006), 'Public spending pressures', in R. Chote, C. Emmerson, R. Harrison and D. Miles (eds), The IFS Green Budget: January 2006,

Commentary no. 100, London: Institute for Fiscal Studies

(www.ifs.org.uk/publications.php?publication $\mathrm{id}=3552$ ).

Clark, T. and Leicester, A. (2004), 'Inequality and two decades of British tax and benefit reforms', Fiscal Studies, vol. 25, pp. 129-58.

Davison, A.C.C. and Hinkley, D.V. (1997), Bootstrap Methods and Their Application, Cambridge: Cambridge University Press.

Department for Work and Pensions (2003), Measuring Child Poverty, London: DWP.

Department for Work and Pensions (2005a), Opportunity for All: Seventh Annual Report, Cm. 6673, London: TSO.

Department for Work and Pensions (2005b), Households Below Average Income 1994/952003/04, Leeds: Corporate Document Services.

Department for Work and Pensions (2006), Households Below Average Income 1994/952004/05, Leeds: Corporate Document Services.

Department of Social Security (various years), Family Credit Quarterly Statistical Enquiry, London: DSS.

Dickens, R. (2000), 'Caught in a trap? Wage mobility in Great Britain 1975-1994', Economica, vol. 67, pp. 477-98.

Francesconi, M. and Van der Klaauw, W. (2004), 'The consequences of "in-work" benefit reform in Britain: new evidence from panel data', Institute for Social and Economic Research, Working Paper no. 2004-13.

Goodman, A., Myck, M. and Shephard, A. (2003), Sharing in the Nation's Prosperity? Pensioner Poverty in Britain, Commentary no. 93, London: Institute for Fiscal Studies (www.ifs.org.uk/publications.php?publication_id=1802).

Goodman, A. and Shephard, A. (2002), Inequality and Living Standards in Great Britain: Some Facts, Briefing Note no. 19, London: Institute for Fiscal Studies (www.ifs.org.uk/publications.php?publication id=1768).

Gregg, P. and Harkness, S. (2003), 'Welfare reform and lone parents employment in the UK', Centre for Market and Public Organisation, Working Paper no. 03/072.

Gregg, P., Waldfogel, J. and Washbrook, E. (2005), 'Family expenditures post-welfare reform in the UK: are low-income families starting to catch up?', Centre for Market and Public Organisation, Working Paper no. 05/119. 
Hills, J. (2001), 'Poverty and social security: What rights? Whose responsibilities?', in A. Park, J. Curtice, K. Thomson, L. Jarvis and C. Bromley (eds), British Social Attitudes: The 18th Report - Public Policy, Social Ties, London: Sage.

Hills, J. (2002), 'Following or leading public opinion? Social security policy and public attitudes since 1997', Fiscal Studies, vol. 23, pp. 539-58.

Hills, J. and Stewart, K. (2005), A More Equal Society, Bristol: Policy Press.

HM Revenue \& Customs (2005a), Child and Working Tax Credits Statistics April 2005, London (www.hmrc.gov.uk/stats/personal-tax-credits/c-wtc-stats-april05.pdf).

HM Revenue \& Customs (2005b), Child and Working Tax Credits Statistics, Finalised Awards 2003/4, Geographical Analyses, London (www.hmrc.gov.uk/stats/personal-taxcredits/geog june05 amendedjul05.pdf).

HM Revenue \& Customs (2005c), Department of Inland Revenue, 2004-05 Accounts, HC 446, London: TSO.

HM Revenue \& Customs (2006), Child Tax Credit and Working Tax Credit Take-Up Rates, 2003-04, London (www.hmrc.gov.uk/stats/personal-tax-credits/takeup_rates_200304 mar06.pdf).

HM Treasury (2003), The Strength to Take the Long-Term Decisions for Britain: Seizing the Opportunities of the Global Economic Recovery, Pre-Budget Report 2003, Cm. 6042, London (www.hm-treasury.gov.uk/pre budget report/prebud_pbr03/prebud_pbr03_index.cfm).

HM Treasury (2004), Opportunity for All: The Strength to Take the Long-Term Decisions for Britain, Pre-Budget Report 2004, Cm. 6408, London (www.hmtreasury.gov.uk/pre budget report/prebud_pbr04/prebud_pbr04_index.cfm).

HM Treasury (2005a), Latest Public Spending Budgetary Data, July 2005, London (www.hm-treasury.gov.uk/media/344/A1/latest budgetary tables_peowp05.xls).

HM Treasury (2005b), Investing for Our Future: Fairness and Opportunity for Britain's Hard-Working Families, Budget 2005, HC 372, London (www.hmtreasury.gov.uk/budget/budget_05/bud_bud05 index.cfm).

HM Treasury (2005c), Public Spending by Function Data, July 2005, London (www.hmtreasury.gov.uk/media/344/99/latest_functional_tables_peowp05.xls).

HM Treasury (2005d), Britain Meeting the Global Challenge: Enterprise, Fairness and Responsibility, Pre-Budget Report 2005, Cm. 6701, London (www.hmtreasury.gov.uk/pre budget report/prebud_pbr05/report/prebud pbr05 repindex.cfm).

Inland Revenue (2003a), Working Families' Tax Credit: Estimates of Take-Up Rates in 200102, London (www.hmrc.gov.uk/stats/wftc/wftc-take-up-2001-02.pdf).

Inland Revenue (2003b), Working Families' Tax Credit Statistics, Summary Statistics, United Kingdom, February 2003, London (www.hmrc.gov.uk/wftctables/wftc_feb03.pdf).

Jarvis, S. and Jenkins, S (1998), 'How much income mobility is there in Britain?', Economic Journal, vol. 108, pp. 428-43. 
McClements, L. (1977), 'Equivalence scales for children', Journal of Public Economics, vol. 8, pp. 191-210.

Office for National Statistics (2005a), Work and Worklessness among Households: July 2005, London: ONS (www.statistics.gov.uk/pdfdir/work0705.pdf).

Office for National Statistics (2005b), United Kingdom National Accounts: The Blue Book 2005, London: ONS (www.statistics.gov.uk/downloads/theme_economy/BB2005.pdf).

Office for National Statistics (2006), Work and Worklessness among Households: January 2006, London: ONS (www.statistics.gov.uk/pdfdir/work0106.pdf).

Sutherland, H. (2002), One Parent Families, Poverty and Labour Policy, London: National Council for One Parent Families.

Sutherland, H., Sefton, T. and Piachaud, D. (2003), Poverty in Britain, York: Joseph Rowntree Foundation. 
